\title{
Geometry of the Butterknowle Fault at Bishop Auckland (County Durham, UK), from gravity survey and structural inversion
}

\author{
Rob Westaway 1,*, Sean M. Watson ${ }^{1}$, Aaron Williams ${ }^{1}$, Tom L. Harley ${ }^{2}$, \\ and Richard Middlemiss ${ }^{3}$ \\ 1 James Watt School of Engineering, University of Glasgow, James Watt (South) Building, \\ Glasgow G12 8QQ, UK. \\ 2 WSP, 70 Chancery Lane, London WC2A 1AF, UK. \\ 3 School of Physics, University of Glasgow, Kelvin Building, Glasgow G12 8QQ, UK. \\ * Correspondence: robert.westaway@gla.ac.uk;
}

\begin{abstract}
The Butterknowle Fault is a major normal fault of Dinantian age in northern England, bounding the Stainmore Basin and the Alston Block. This fault zone has been proposed as a source of deep geothermal energy; to facilitate the design of a geothermal project in the town of Bishop Auckland further investigation of its geometry was necessary and led to the present study. We show using three-dimensional modelling of a dense local gravity survey, combined with structural inversion, that this fault has a ramp-flat-ramp geometry, $250 \mathrm{~m}$ of latest Carboniferous / Early Permian downthrow having occurred on a fault surface that is not a planar updip continuation of that which had accommodated the many kilometres of Dinantian extension. The gravity survey also reveals relatively low-density sediments in the hanging-wall of the Dinantian fault, interpreted as porous alluvial fan deposits, indicating that a favourable geothermal target indeed exists in the area. This study demonstrates the value of gravity data for elucidating geological structure, even in a well-studied region such as Britain, and highlights the need to verify published structural interpretations as future deep geothermal projects are designed. Future work of this type might be undertaken more expeditiously using microelectromechanical gravimeters.
\end{abstract}

Keywords: U.K.; England; County Durham; Bishop Auckland; Butterknowle Fault; geothermal, gravity survey; structural inversion.

\section{Introduction}

Roughly half the energy demand in the UK is for space heating, this demand being largely met at present by burning fossil fuels, primarily natural gas. The geothermal heat resource in the UK is well known to be very large (e.g., [1,2]), the surface heat flow exceeding $100 \mathrm{~mW} \mathrm{~m}^{-2}$ across much of northern and SW England (e.g., [3]), especially after raw subsurface temperature measurements are corrected for palaeoclimate [4]. The technical challenges underlying deep geothermal energy are similar to those for the petroleum industry. However, because heat is an inherently lower-value commodity than hydrocarbons, exploration success rates that are economic in the latter field would not be sustainable in the former, making deep geothermal exploration an inherently 'risky' prospect. Successful deep geothermal projects in regions such as the Netherlands and eastern France (the Upper Rhine valley) have indeed depended on well data from previous exploration for hydrocarbons. A need therefore exists to demonstrate the feasibility of low-cost deep geothermal exploration techniques, under conditions applicable to Britain, in localities where no previous exploratory drilling for hydrocarbons has taken place. The need for cost-effective options is graphically illustrated by the current UK Geoenergy Observatories (UKGEOS) geothermal infrastructure project in Scotland (e.g., [5,6,7]), whose $£ 9 \mathrm{M}$ budget may well exceed by orders-ofmagnitude the value of the geothermal heat that might ultimately be produced at the site. 


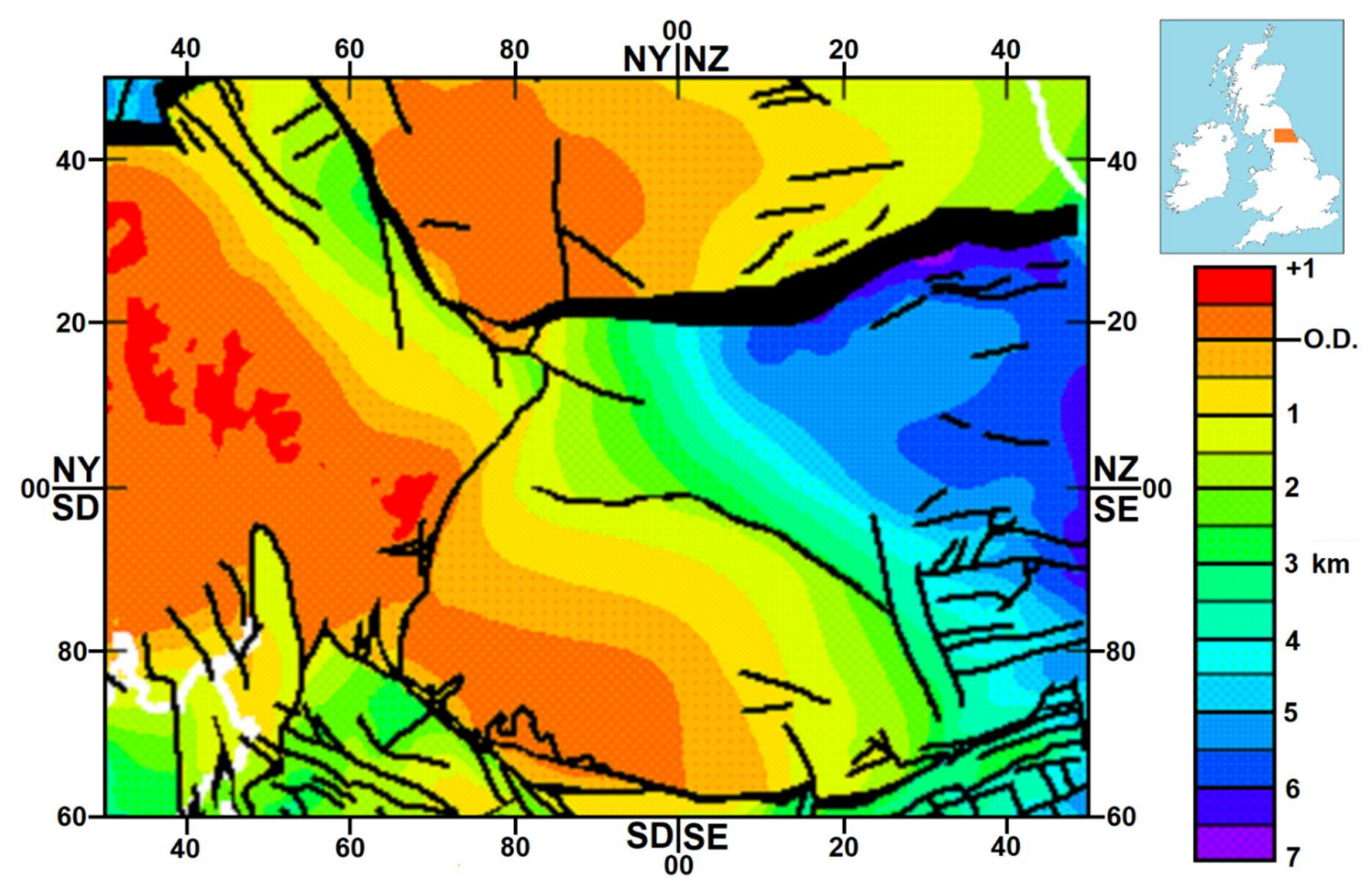

Figure 1. Colour-shaded map of the depth relative to O.D. of the top of the Lower Palaeozoic Metamorphic Rocks across much of northern England, modified from Kimbell et al. [8]. This and other maps are indexed to the British National Grid (BNG) [9], with co-ordinates labelled in $\mathrm{km}$. The area south and west of NZ 500000 is redrawn from Map 1 of Kirby et al. [10] and that for the area in Fig. 2 (i.e., north and east of NY 600100 and north and west of NZ 300 100) is derived from Map 1 of Chadwick et al. [11], in both cases with reduced vertical resolution (500 m instead of $200 \mathrm{~m})$. This depiction of the depth of the base of the sedimentary column is an example of a public output from the BGS Lithoframe three-dimensional (3-D) subsurface Geographical Information System (GIS) (cf. Busby and Terrington, [12]). The Closehouse-Lunedale-Butterknowle fault zone runs WSW-ENE across the NE part of the area, separating the upthrown Alston Block to the north from the downthrown Stainmore Basin to the south. The Pennine fault zone and Dent Fault bound the western margin of the Alston Block and Stainmore Basin. The Stockdale Fault bounds the southern margin of the Stainmore Basin and the northern margin of the upthrown Askrigg Block. The Craven fault zone, in the south of the map area, bounds the southern margin of the Askrigg and Lake District blocks and the northern margin of the downthrown Craven Basin. These major normal fault zones formed to accommodate Early Carboniferous crustal extension, as discussed in the text. The inset provides location. This figure is published with permission under British Geological Survey (BGS) permit CP19/053. It is modified from BGS material (c) UKRI 2019, with all rights reserved.

The Bouguer gravity low in the North Pennine uplands of northern England was first interpreted as a consequence of the low-density subsurface Weardale Granite by Bott and Masson-Smith [13,14] and confirmed shortly thereafter by drilling of the Rookhope borehole [15] (Figs 1, 2). The heat flow of $92 \mathrm{~mW} \mathrm{~m}^{-2}$, determined by Bott et al. [16] from measurements in this borehole (and uncorrected for palaeoclimate; cf. [4], is relatively high due to radioactive heat production in this granite. Bott et al. [16] also reported heat flow of $96 \mathrm{~mW} \mathrm{~m}^{-2}$ in the Woodland borehole, located (at NZ 0909627694 ) south of the Weardale Granite and within $\sim 2 \mathrm{~km}$ of the Butterknowle Fault (Figs 3, 4), one of the principal normal faults of Carboniferous age in the region (Fig. 2). These authors tentatively attributed this high value to upward flow of groundwater, heated at depth by the granite, exploiting 


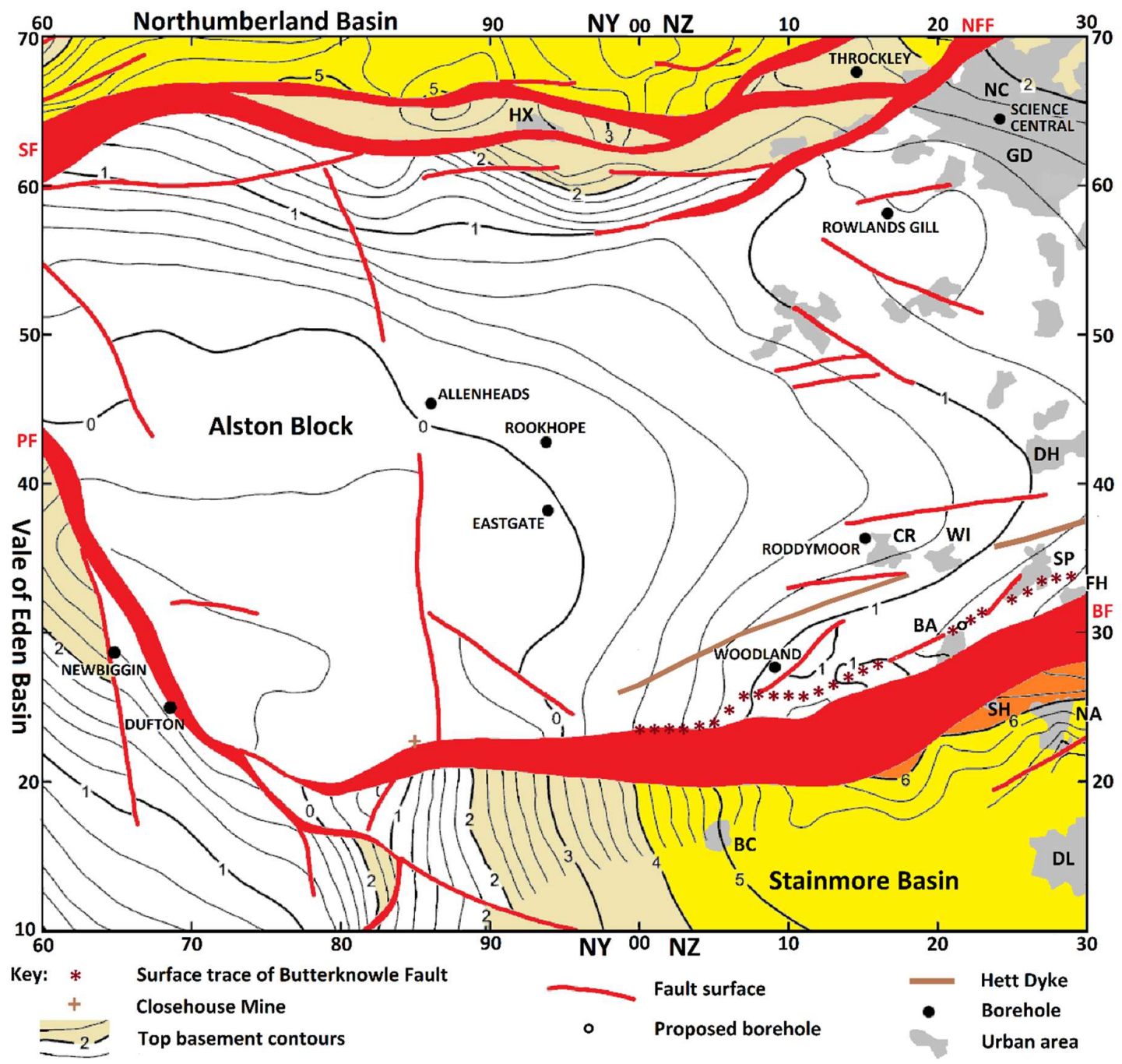

Figure 2. Map of the Alston Block showing structural elements and major faults, with contours to indicate depth relative to O.D. of the top of the Lower Palaeozoic Metamorphic Rocks, modified from Fig. 3 of Kimbell et al. [17] with shading to emphasize deep sedimentary basins, based on Map 1 of Chadwick et al. [11], after Whittaker [18]. This depiction of the depth of the base of the sedimentary column was digitized in 2004 to create the BGS Lithoframe 3-D subsurface GIS (cf. Busby and Terrington [12]). Location of the Science Central (or Newcastle Helix) borehole is from Westaway and Younger [19]. Major faults are abbreviated thus: BF, Butterknowle Fault, and its western continuation as the Lunedale and Closehouse faults; NFF, Ninety-Fathom Fault; PF, Pennine Fault; and SF, Stublick Fault. Placenames are abbreviated thus: BA, Bishop Auckland; BC, Barnard Castle; CR, Crook; DH, Durham; DL, Darlington; FH, Ferryhill; GD, Gateshead; HX, Hexham; NA, Newton Aycliffe; NC, Newcastle upon Tyne; SH, Shildon; SP, Spennymoor; and WI, Willington. The Weardale granite is thought to extend in the subsurface throughout most of the Alston Block, its southern margin being placed by Kimbell et al. [17] 8-10 km north of the Butterknowle Fault from the vicinity of the Woodland Borehole eastward, and nearer this fault farther west.

this fault zone that was assumed to have relatively high permeability. This region has also hosted the only two deep geothermal boreholes to have been drilled in Britain in more than two decades (prior to 2018): at Eastgate [20] and at the Science Central (now 'Newcastle Helix') site in Newcastle upon Tyne $[19,21]$. The Eastgate borehole, near its Rookhope predecessor in the centre of the Alston Block, has yielded the highest raw heat flow measurement in the region, $115 \mathrm{~mW} \mathrm{~m}^{-2}$ [20]. The Bott et al. [16] conceptual model for the Butterknowle Fault inspired the Science Central geothermal project, which involved drilling adjacent to the Ninety Fathom Fault at the northern margin of the Alston 
Block in the city centre of Newcastle upon Tyne [19,21]. However, the Dinantian age sandstone in this locality proved to be extremely tight, no upflow of thermal water at depth being evident.

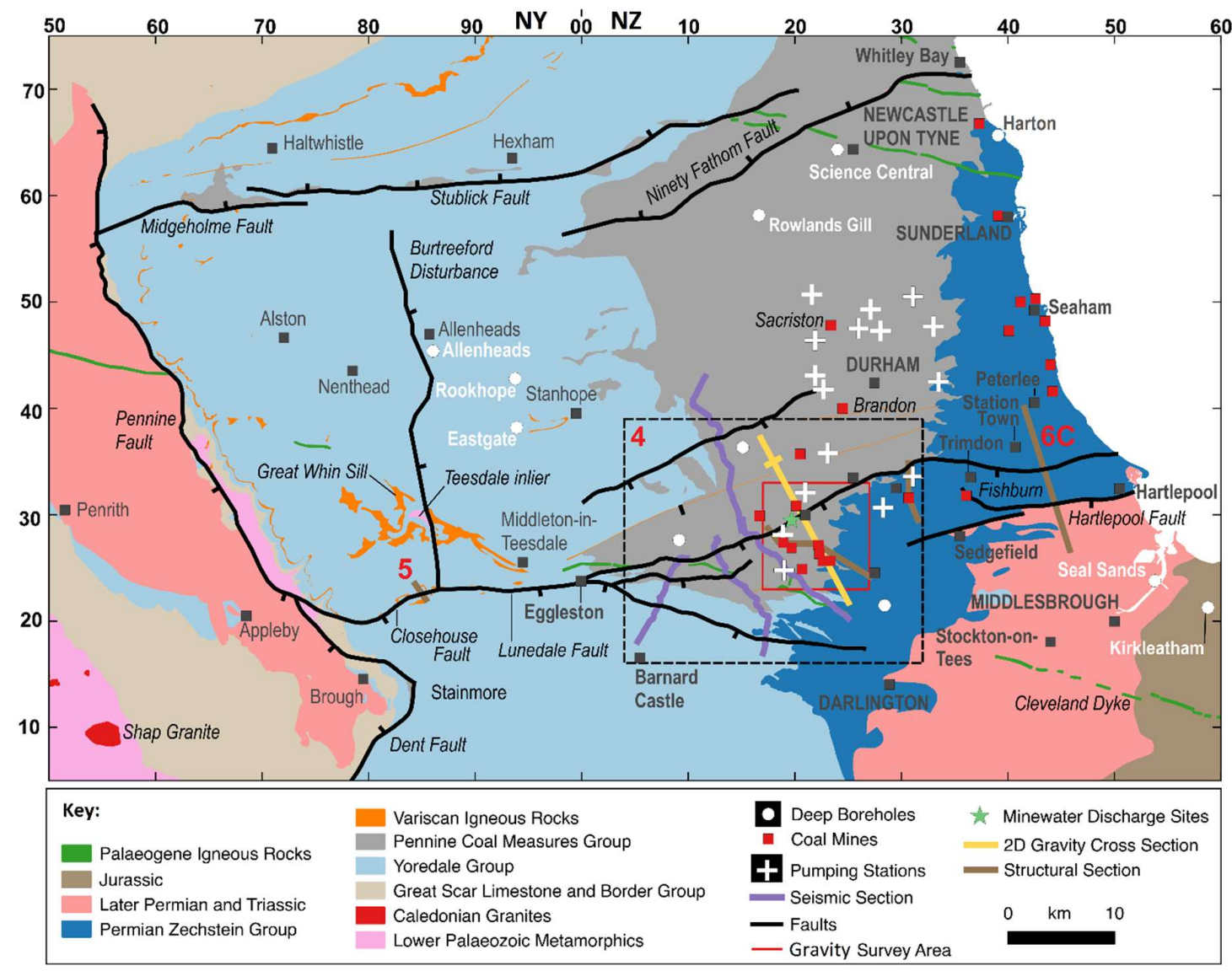

Figure 3. Regional location map, showing simplified geology and localities discussed in the text, including locations of other figures. Only coal mines discussed in the text are shown (see, e.g., [22,23] for more detail).

In 2014 plans for another deep geothermal project began to emerge, again proposing to utilize the Bott et al. [16] conceptual model. Near the town of Bishop Auckland the Butterknowle fault zone has been depicted (e.g., by Kimbell et al. [17]; Fig. 2) as consisting of two subparallel SSE-dipping normal faults, $\sim 1.5 \mathrm{~km}$ apart, both offsetting the Lower Palaeozoic metamorphic rocks (LPMR) beneath the Carboniferous sedimentary succession. The more northerly of these interpreted faults passes through the project site (Auckland Castle, at British National Grid (BNG) reference NZ 21362 30213) and was identified as the drilling target. Work progressed to the point of designing the layout of the drilling pad and its access facilities, envisaging sub-vertical drilling to intercept this steep fault (which we designate as the 'Castle Fault') within the LPMR at $1.6 \mathrm{~km}$ depth, where a temperature of $>80^{\circ} \mathrm{C}$ (suitable for heating estate buildings) might be estimated by extrapolation of the Bott et al. [16] geothermal gradient for the nearby Woodland borehole. The present study was commissioned as an attempt to validate the conceptual model that had been assumed, in order to derisk the drilling process. A subsequent application for funding towards the capital cost of a modified well design, based on the amended structural concept established by this study, did not succeed; no plans currently exist for further geothermal investigation at this site. 


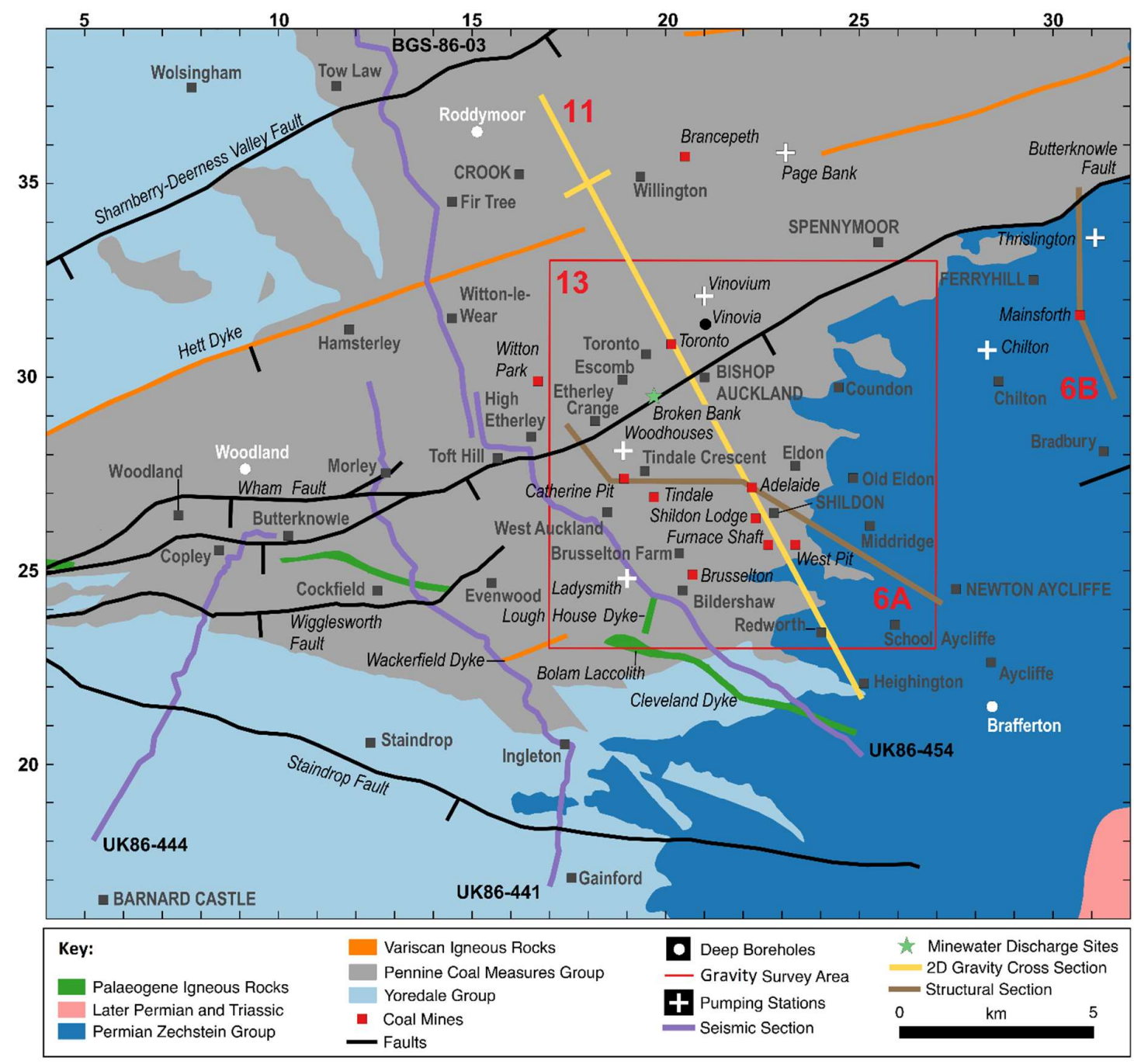

Figure 4. More detailed location map, showing the present gravity survey area and its immediate surroundings. See Fig. 3 for location.

The present account will, first, summarize the history of research on this study region. To facilitate location of sites, Fig. 2 shows named localities across the region, with Figs 3 and 4 providing more detail on localities closer to our study site. This summary will include discussion of seismic reflection profiles that transect the Butterknowle Fault and provide information on its geometry. These profiles have previously been published without precise location details. Now that the survey metadata are in the public domain, more precise location and structural interpretation is possible. We then discuss the history of mining and mine dewatering in the study region. Such data are relevant to our analysis because the mine records have contributed much structural detail and changes in crustal mass accompanying the ending of dewatering need to be taken into account when integrating our new gravity data with previous work. We next summarize our approach to structural analysis for the Butterknowle Fault. We then describe our gravity survey, reporting its design process and implementation followed by the data analysis and three-dimensional numerical modelling. We finally discuss the resulting structural interpretation and assess the significance of our results.

\section{History of Research}

Many aspects of the structure of the North Pennines were deduced centuries ago by miners, and were compiled in early 19th century accounts including the works of Forster [24] and Sopwith [25]. Some faults in this region, such as the Stublick and Pennine faults (Fig. 2), dominate the topography, 
their importance being recognized at an early stage. However, the Closehouse-LunedaleButterknowle fault zone, the subject of the present study, lacks clear topographic expression and its importance was long unrecognized. Bott and Masson-Smith [14] reported a southward decrease in the Bouguer gravity anomaly by up to $\sim 14$ mgal across the line of this fault zone, which they tentatively explained as a consequence of a significant southward thickening of the Carboniferous sediment, this being the first suggestion that the Stainmore syncline or trough follows the line of a deep sedimentary basin of Carboniferous age. Subsequently, Burgess and Mitchell [26] showed that the upper part of the Dinantian succession thickens abruptly southward across the ClosehouseLunedale Fault then thins gradually southward towards the Askrigg Block, consistent with deposition during slip on this fault. Following the publication of McKenzie's [27] physical model for syn-extensional subsidence and subsequent thermal subsidence governing the development of sedimentary basins, Bott et al. [28] were the first to interpret the Stainmore Trough on this basis. Several workers (e.g., $[29,30])$ subsequently published interpretations of seismic reflection surveys, shot mainly for hydrocarbon exploration, demonstrating many kilometres thickness of Dinantian sediment. This was explained as a consequence of extension of the continental crust that overlay northward subduction, beneath southern Britain, of oceanic crust (e.g., [31]), the geometry being similar to the modern Aegean region that overlies the subducting African plate. A regional synthesis of data [11] and updated modelling of the gravity dataset [17] have followed. The Variscan Orogeny has likewise been placed in its plate tectonic context (e.g., [32]).

Terrington and Thorpe [33] have described the process of building the geometry of faulting proposed by Chadwick et al. [11] (including their 'take' on the geometry of the Butterknowle Fault) into a subsurface GIS, although without any reassessment of the results of the earlier study. Other recent developments include the realisation that this study region was covered by $\geq 1 \mathrm{~km}$ of Mesozoic sediment, since lost to erosion, that much (most?) of the present topography is very young (Late, or latest, Cenozoic), and thus unrelated to the Carboniferous crustal extension, and of the potential role of processes during the Palaeogene British Tertiary Igneous Province (BTIP) magmatism in triggering the erosion that has created the present crustal configuration (e.g., $[34,35,36])$.

The shallow geological structure of this study region has been largely determined through centuries of mining: metalliferous mining in the central and western Alston Block, which experienced prolonged hydrothermal mineralization above the Weardale Granite; coal mining in the former Durham coalfield farther east. As Figs 3 and 4 indicate, outcrop is dominated by Carboniferous rocks, details being provided in many works (e.g., [37,38,39]). In the Alston Block this Carboniferous succession unconformably overlies the LPMR, metasediments of probable Ordovician age into which the Devonian Weardale Granite is intruded, the geometry of this unconformity, with its gentle ENE tilt, being illustrated in Fig. 2 .

The region was affected by quartz-doleritic magmatism around the start of the Permian boundary, involving intrusion of the Great Whin Sill and emplacement of the associated WSW-ENEtrending dykes, such as the Hett Dyke that adjoins the Butterknowle Fault (Figs 2, 3, 4). The thickness of the sill is $\sim 60-70 \mathrm{~m}$ in its famous outcrop area in upper Teesdale (Fig. 3), but variations have been documented [40,41], the greatest thickness proved being $99 \mathrm{~m}$ in the Harton borehole near Newcastle upon Tyne (Fig. 3). This sill is dated to $297.4 \pm 0.4( \pm 2 \sigma)$ Ma [42], the associated Holy Island Dyke being dated to $294 \pm 2 \mathrm{Ma}$ [43]. These dates are coeval with a suite of Ar-Ar dates for intrusive igneous rocks in central Scotland spanning 298.3 \pm 1.3 Ma to 292.1 \pm 1.1 Ma [44]. The Great Whin Sill has no outcrop south of the Hett Dyke, thought to be a major feeder, which led to the long-standing presumption that it is not present farther south in the subsurface [45]. The drilling of the Roddymoor borehole in 1920, which proved a $57 \mathrm{~m}$ thickness of this sill south of this dyke (e.g., [11]), and of the Woodland borehole in 1962, which bottomed within the sill, proving a $20 \mathrm{~m}$ thickness (e.g., [11]), demonstrate that it is more extensive than previously thought.

Recent syntheses $[8,48]$ have proposed that the Closehouse-Lunedale-Butterknowle fault zone marks the southern limit of the Great Whin Sill. However, at Closehouse mine this sill, fed by magma extruded up this fault, evidently persists for some distance to the south (Fig. 5). The outcrop of the 


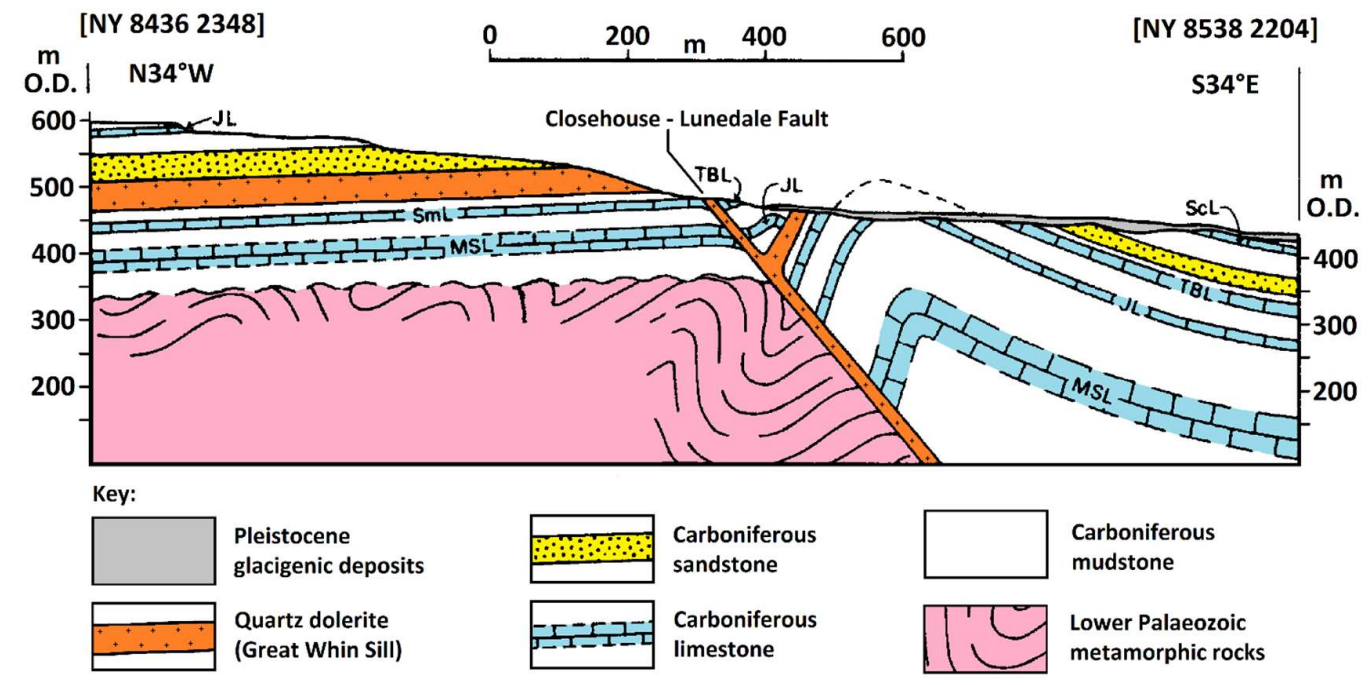

Figure 5. Structural cross-section across the Closehouse Fault in the vicinity of Closehouse Mine (see Fig. 2 or Fig. 3 for location), modified from part of Fig. 3 of Cornwell and Wadge [46]. Limestone beds are identified thus: ScL, Scar Limestone; TBL, Tyne Bottom Limestone; JL, Jew Limestone; SmL, Smiddy Limestone; and MSL, Melmerby Scar Limestone. The Waters et al. [47] stratigraphy assigns the sequence above the MSL to the Alston Formation of the Yoredale Group, and the MSL and the underlying sediments to the Great Scar Limestone Group.

quartz dolerite Wackerfield Dyke (circa NZ 160 230) (Fig. 4), regarded as of Variscan age (e.g., [37]), also makes clear that this magmatism is not confined to the area north of this fault. Furthermore, likewise south of the Butterknowle Fault (Fig. 3), a $16 \mathrm{~m}$ thickness of the Great Whin Sill is encountered in the Seal Sands borehole, at depths between 1022 and $1038 \mathrm{~m}$ [11,49]. Farther east, the Kirkleatham borehole (BGS record NZ52 SE6, at NZ 58788 21284) reached deep into the Carboniferous succession but did not encounter the sill; its limit in this area evidently lies between these boreholes. The Great Whin Sill is not mentioned in the cursory accounts of the confidential, 1987 m Brafferton borehole (BGS record NZ22 SE105, at NZ 28432 21493) to be published (e.g., $[11,49])$, but this may simply reflect limited disclosure. Liss et al. [48] suggested that the subsurface extent of the Great Whin Sill can be inferred from a characteristic 'texture' of short-wavelength magnetic anomalies, and reported that on this basis the Butterknowle Fault marks its southern limit. However, the same 'texture', albeit of lower amplitude, can be seen in the improved magnetic anomaly maps (colour-shaded, with synthetic 'shadow' effects) provided by Kimbell et al. [8] to persist southeastward to the Tees estuary (circa NZ 560 230) and westward from this point to the vicinity of the Wackerfield dyke (Fig. 4). Moreover, such a disposition is to be expected from considerations of pressure equilibrium during magma emplacement (e.g., [41]); the same considerations indicate that magma intruded into a 'structural low' (e.g., the hanging-wall of the Butterknowle Fault) from a neighbouring 'structural high' (e.g., the vicinity of the Hett Dyke) is likely to 'pond' to significant thickness. These considerations are significant for the present study, because the Great Whin Sill quartz dolerite is much denser than the sediments into which it has intruded ( 2900 versus $\sim 2500 \mathrm{~kg} \mathrm{~m}^{-3}$; see below), so its presence or absence will have a significant effect on gravity anomalies. From standard theory (see also below) the presence or absence of a $100 \mathrm{~m}$ thickness of the Great Whin Sill will affect gravity by $\sim 1.7 \mathrm{mgal}$, a value significant relative to the tolerance to which our study has been conducted.

In the SE part of the study region the Carboniferous succession is overlain, above the 'Variscan unconformity', by the dolomitic 'Magnesian Limestone', nowadays known as the Zechstein Group, of Late Permian age, and the overlying Mesozoic succession (Fig. 3). Thermochronologic studies indicate erosion of $\sim 1 \mathrm{~km}$ of uppermost Carboniferous rocks prior to emplacement of this Permian succession (e.g., [51]). The youngest pre-Pleistocene rocks in the region are tholeiitic dykes, such as 

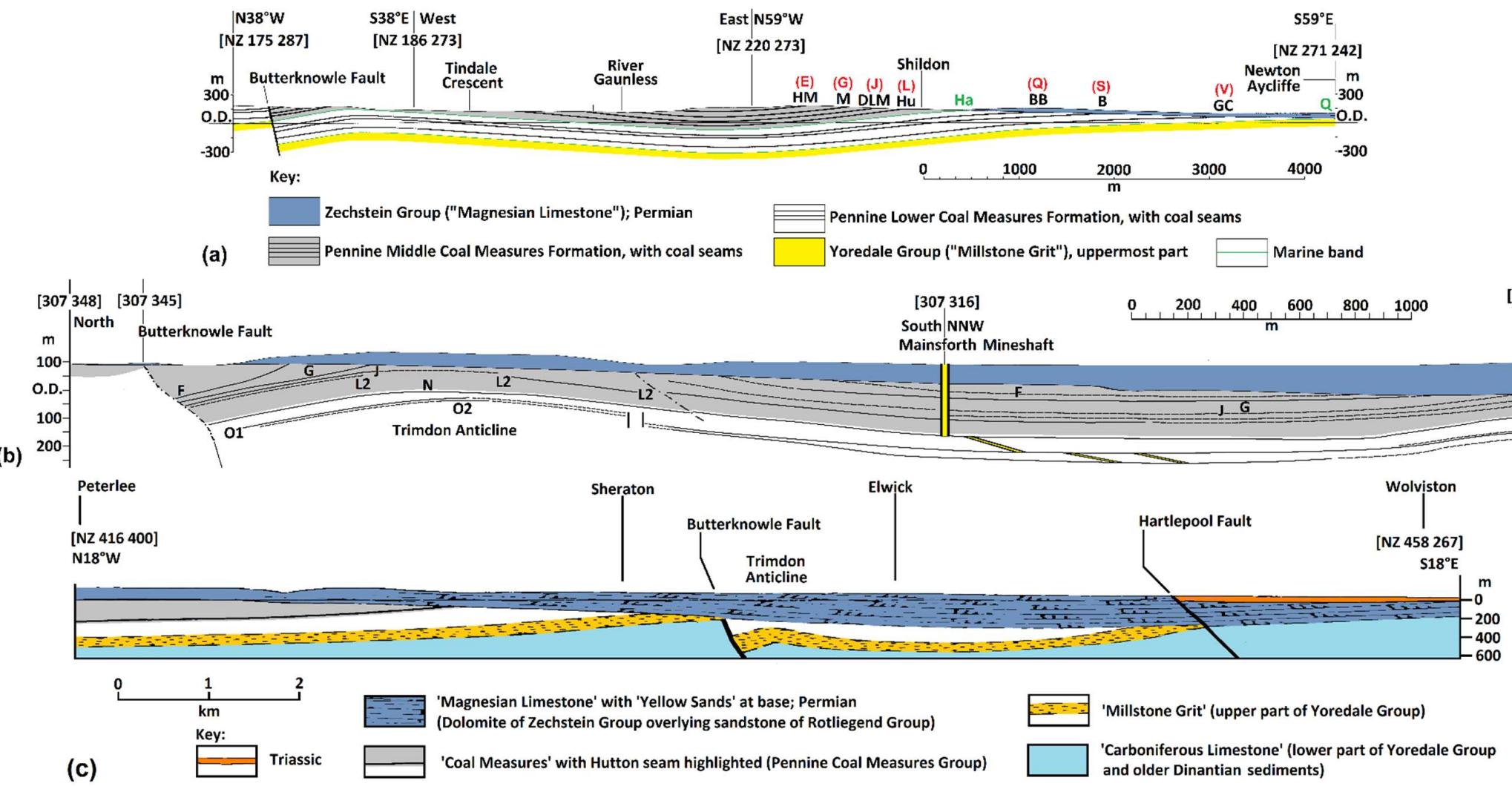

Figure 6. Cross-sections across the central and eastern Butterknowle Fault. (a) To the west and south of Bishop Auckland (crossing the surface trace of the Butterknowle Fault at NZ 17724 28410), with overall WNW-ESE orientation, modified after cross-section 2 of [50]. Coal seams are: HM, High Main; M, Main; DLM, Durham Low Main; Hu, Hutton; BB, Bottom Busty; B, Brockwell; and GC, Ganister Clay, each followed by letters assigned by the former National Coal Board (NCB), after Mills \& Holliday [39]. Marine bands are: Ha, Harvey; and Q, Quarterburn. (b) Along a line 10 km ENE of (a), from Fig. 2 of Cairney and Frost [52], structure north of the Butterknowle Fault being schematic. The Mainsforth Colliery mineshaft and inclined haulage roadways between coal seams are highlighted. Seams are labelled using NCB letters, which correlate with names (after [39]) thus: F, Five-Quarter or Metal; G, Brass Thill or Main; J, Durham Low Main; L2, Hutton; N, Harvey; O1 and O2, Hodge; and S, Brockwell. (c) Along a line $\sim 10 \mathrm{~km}$ east of (b), from Fig. 6 of Bott and Masson-Smith [14]. 


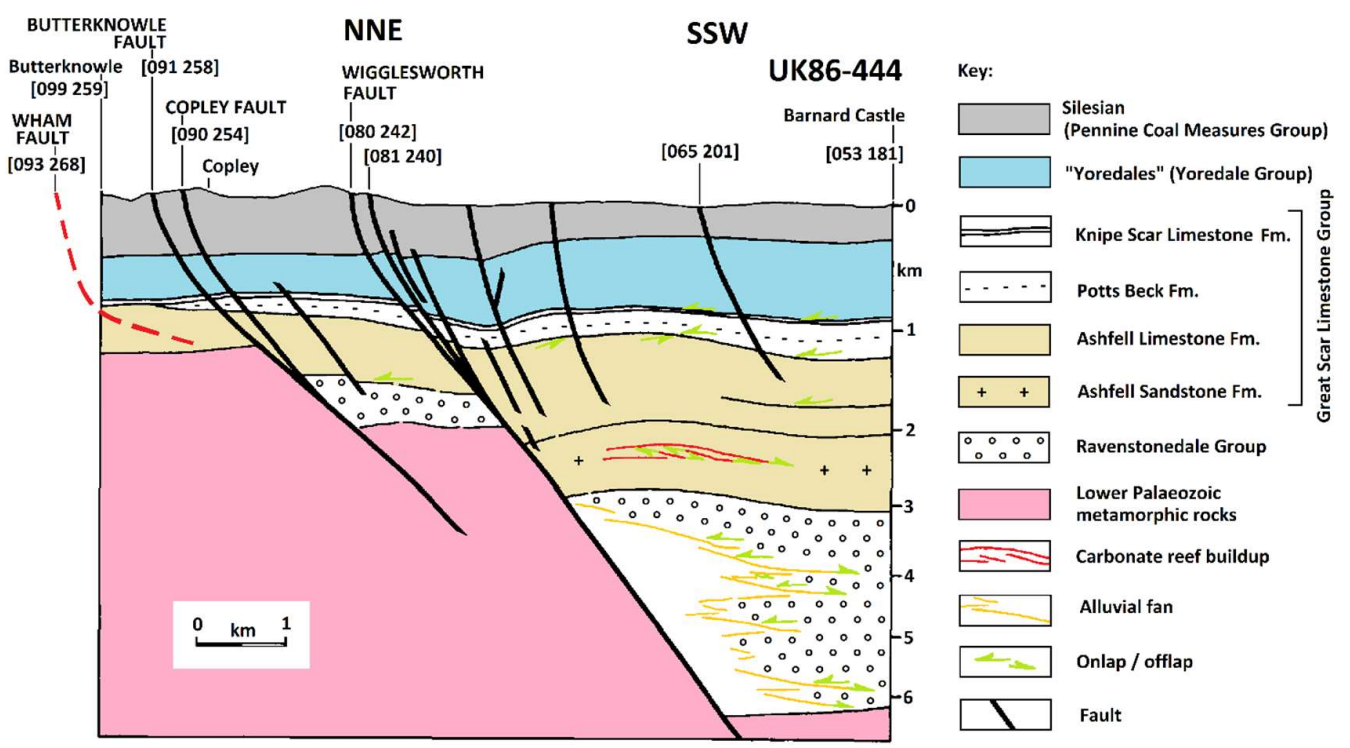

Figure 7. Cross-section across the western part of the Butterknowle Fault Zone, to the west of Butterknowle, modified from Fig. 2(b) of Collier [30], with geo-location.

the Cleveland Dyke, and associated intrusions, such as the Bolam Laccolith, emplaced during the Palaeogene BTIP magmatism. Figure 5 illustrates the geological structure alongside the Closehouse Fault, the westward continuation of the Butterknowle Fault, in the vicinity of the former Closehouse mine. Figure 6 illustrates the structure adjoining the Butterknowle Fault near Bishop Auckland and in localities farther east; folding of the Carboniferous sediments and their erosional truncation by the 'Variscan unconformity' are evident. Figures 7, 8, and 9 show seismic sections crossing this fault.

The Carboniferous rocks in this region were historically subdivided into the 'Carboniferous Limestone', 'Millstone Grit', and 'Coal Measures' series. From the 1990s onward multiple attempts have been made to replace these historical designations with a formal stratigraphy; this has resulted in a proliferation of nomenclature [19], with some new names for formations and other subdivisions being introduced then superseded in quick succession. We have adopted the nomenclature introduced by Waters et al. [47] and Stone et al. [53]; the stratigraphy reported in other works has been updated accordingly. The upper part of the succession, of Westphalian age, is now known as the Pennine Coal Measures Group (PCMG), subdivided into the Pennine Lower Coal Measures Formation (PLCMF) and Pennine Middle Coal Measures Formation (PMCMF), the former spanning the Westphalian A stage (the Langsettian) and the latter the Westphalian B and C stages (the Duckmantian and Bolsovian). The local nomenclature for coal seams is illustrated in Fig. 6. These successions indicate cyclic alternations in depositional environments (marine, deltaic, fluvial channel, floodplain, etc.), reflecting adjustments of depositional systems to sea-level variations caused by contemporaneous glaciation (e.g., $[54,55,56$ ). The sediments beneath the PCMG are now designated as the Yoredale Group, comprising the Stainmore Formation of Namurian age, overlying the Alston Formation, representing the Brigantian substage of the Visean. These successions also reflect cyclic alternations in environments and lithologies, the Stainmore Formation being mudstone-dominated and the Alston Formation limestone-dominated. The top of the underlying Great Scar Limestone Group, representing the Chadian, Arundian, Holkerian and Asbian substages of the Visean, is defined by a regionally-traceable limestone unit, the Melmerby Scar Limestone (Fig. 5) or Knipe Scar Limestone. The Alston Block interior is inferred to have been largely subaerial, without deposition, prior to the Asbian (e.g., [11]). The basal part of the Stainmore Basin succession, representing the Tournaisian stage (e.g., [57]), is known as the Ravenstonedale Group. Chadwick et al. [11] placed the main phase of crustal extension spanning the Tournaisian through to the Holkerian substage of the Visean. The post-rift succession thus began in the Asbian, making the Potts Beck Formation (cf. Figs 7 and 9) the oldest sediment from this phase. ICS [58] assigns the base and top of the Tournaisian (or 
Courceyan) stage to 359 and $347 \mathrm{Ma}$ and the top Visean to $331 \mathrm{Ma}$. The Chadian to Holkerian substages span maybe ten million years of the $\sim 16$ million year duration of the Visean (cf. [57]); the crustal extension thus lasted $\sim 22$ million years, between $\sim 359$ and $\sim 337 \mathrm{Ma}$.
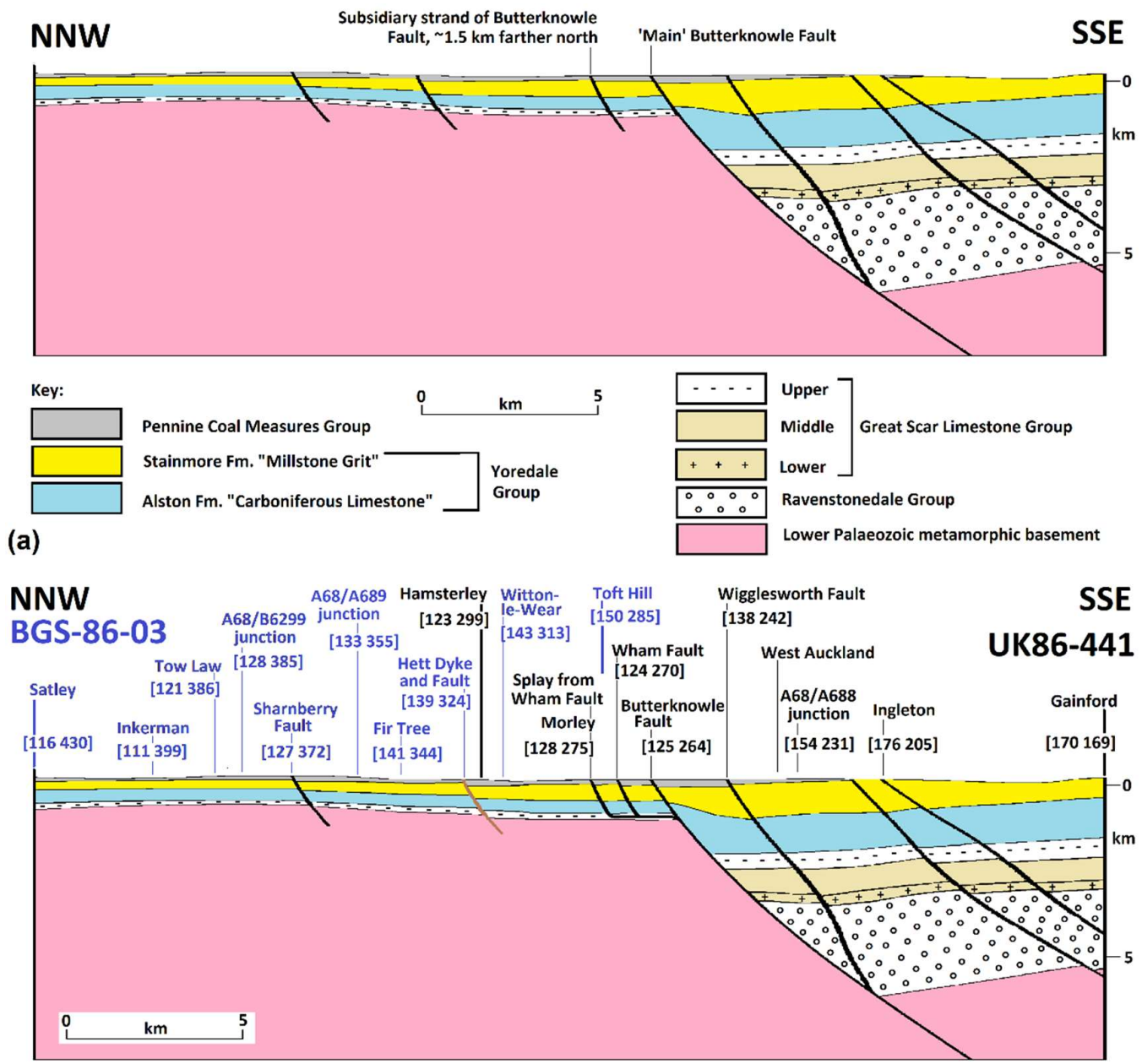

(b)

Figure 8. Cross-sections based on seismic reflection studies. (a) Modified from part of Fig. 12(a) of Chadwick et al. [11]. (b) Revised and amended, with geo-location. The geo-location establishes that the NNW part of this composite section, from Satley to Toft Hill, is based on seismic line BGS-86-03 (blue ornament), whereas its SSE part, from Hamsterley to Gainford, is based on line UK86-441 (black ornament). These seismic lines overlap for $\sim 4 \mathrm{~km}$ length at points $\sim 3 \mathrm{~km}$ apart.

As already noted, several illustrations of seismic reflection record sections crossing the Butterknowle Fault and depicting these Carboniferous successions have been published, although without disclosure of co-ordinates. Now that locations of all onshore seismic surveys in Britain are in the public domain (see, e.g., https://ukogl.org.uk/map/), one may use 'clues' in the various publications to geolocate their illustrations. Figure 2 of Collier [30] thus depicts seismic line UK86444, which runs generally NNE-SSW between Butterknowle and Barnard Castle (Fig. 7), crossing the Butterknowle Fault 13 km WSW of Bishop Auckland (circa NZ 091 258). Farther east, Fig. 12 of Chadwick et al. [11] (Fig. 8(a)) is a composite of profile BGS-86-03, which runs NNW-SSE through the Alston Block, much of it (between Tow Law and Toft Hill) along the A68 trunk road. As illustrated in Fig. 8(b), this is composited with profile UK86-441 which also runs generally NNW-SSE, between Hamsterley in the Alston Block and Gainford in the Stainmore Basin, crossing the Butterknowle Fault $\sim 9 \mathrm{~km}$ WSW of Bishop Auckland (circa NZ 125 262). These two seismic lines thus overlap for $\sim 4 \mathrm{~km}$ distance through points $\sim 3 \mathrm{~km}$ apart (Figs. 3, 4). Figure 13 of Chadwick et al. [11] depicts profile UK86- 
454, which runs generally NW-SE along the A68 trunk road, between Toft Hill and the junction with the A6072 trunk road near Newton Aycliffe (Fig. 9). At its NW end this profile overlaps for $\sim 1 \mathrm{~km}$ with the SSE end of BGS-86-03; it crosses the Butterknowle Fault at High Etherley (circa NZ 165 280), $\sim 1 \mathrm{~km}$ WSW of the NW end of Fig. 6(a) and $\sim 5 \mathrm{~km}$ WSW of Bishop Auckland.

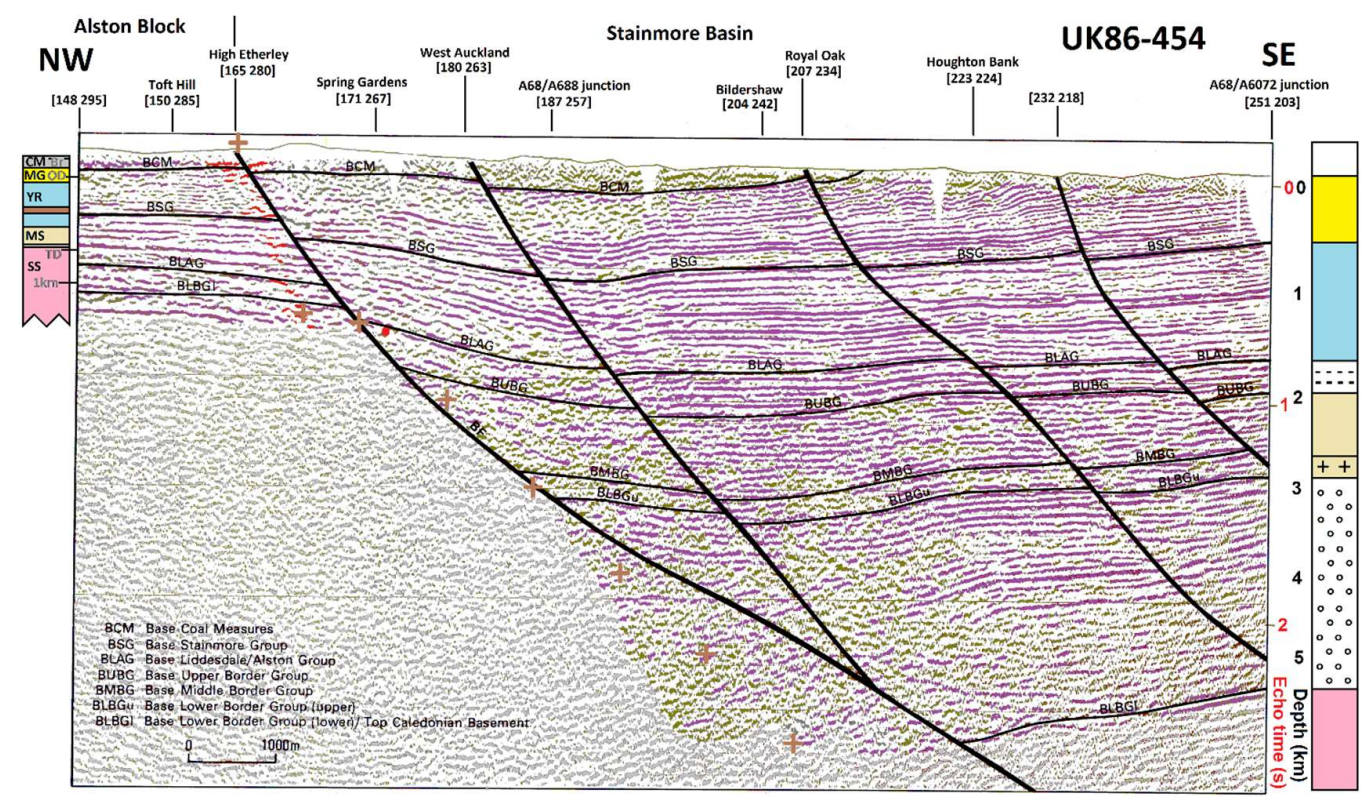

Figure 9. Record section for seismic line UK86-454, modified from Fig. 13 of Chadwick et al. [11], with geo-location. In terms of the modern stratigraphy, the labelling denotes: BCM, base of Pennine Coal Measures Group (PCMG); BSG, base of Stainmore Fm.; BLAG, base of Alston Fm. and Yoredale Group; BUBG, base of Potts Beck Fm.; BMBG, base of Ashfell Limestone Fm.; BLBGu, base of Great Scar Limestone Group; and BLBGl, base of Ravenstonedale Group and top of Lower Palaeozoic metamorphic rocks. Inset shows simplified stratigraphic log from the Roddymoor borehole (at NZ 15127 36229, $7 \mathrm{~km}$ beyond the northern end of the seismic section), from Woolacott [59]. Abbreviations on inset denote, in stratigraphic order: CM, 'Coal Measures' (now PCMG), with Br denoting the Brockwell coal seam; MG, 'Millstone Grit' (now Stainmore Fm.), with OD denoting the Ordnance Datum for sea-level; YR, 'Yoredale Rocks' (now Alston Fm.), including the intrusion by the $57 \mathrm{~m}$ thick Great Whin Sill; MS, 'Melmerby Scar Limestone Series' (now Great Scar Limestone Group), underlain by the 'Basement Conglomerate Series'; and SS, 'Skiddaw Slates' (Lower Palaeozoic metamorphic rocks), with TD denoting the total depth of the borehole, $887 \mathrm{~m}$ below the land surface or $689 \mathrm{~m}$ below OD. This figure is published with permission under British Geological Survey (BGS) permit CP18/049. It is modified from BGS material @ UKRI 2018, with all rights reserved.

\section{History of mining and mine dewatering}

Coal was mined on a small scale in the Durham coalfield for centuries prior to the industrial revolution. Mining on an 'industrial' scale began in the Bishop Auckland area, the SW extremity of the coalfield, in 1825, with the most intense development after 1850 (e.g., [60]). This activity was stimulated by the development of railways, notably the opening of the pioneering Stockton and Darlington Railway to Shildon, West Auckland and Witton Park Colliery (NZ 167 299) in 1825 (e.g., [61]); this provided, for the first time, the means of efficiently transporting coal to the coast at Stockton-on-Tees, where it could be shipped to consumers. As Westaway and Younger [19] have noted, coal mining ceased in 1985 in the inland part of this coalfield (with the closure of Sacriston Colliery, NW of Durham; NZ 234 478), where the PCMG is exposed at outcrop, and in 1993 with the closure of the last mines in the coastal part of the coalfield, where the PCMG is overlain by Permian rocks (Fig. 3). This mining required dewatering, in some localities to depths of hundreds of metres. Mining also created subsurface voids along worked coal seams (many worked using the 'bord and 
pillar' method leaving pillars of intact coal to provide roof support). Subsequent rises in the water table following the end of dewatering will have changed the subsurface density distribution, affecting surface gravity measurements; the history of mining is thus relevant to the present analysis.

Nonetheless, during our fieldwork in 2015 we did not consider the possibility that abandonment of the coalfield, and the resulting flooding of subsurface volumes that had been formerly dewatered, might cause measurable effects on gravity anomalies. Bateson and Lawrence [62] had reported uplift accompanying the flooding of mineworkings following the final abandonment of the Durham coalfield in the 1990s, which demonstrates significant porosity of the flooded rocks, but made no measurements of any associated changes to gravity. Kennedy et al. [63] reported gravity changes of no more than $\sim 0.04 \mathrm{mgal}$ accompanying $\sim 300 \mathrm{~m}$ changes in the water level in the former Homestake gold mine in South Dakota; such small changes would not be resolvable by our gravity survey. Nonetheless, during the course of our data processing mismatches between our gravity data and extant BGS gravity measurements became evident (see below), which are explicable as consequences of the ending of subsurface dewatering after their measurements were made. We therefore briefly summarize the history of mining and associated dewatering in the study area.

The Butterknowle Fault is well known to have formed an aquiclude within the Durham coalfield, the regions north and south of it having been hydraulically distinct (e.g., $[60,64,65])$. Coal mining in the Bishop Auckland area, south of the Butterknowle Fault, progressively ended between the 1920s and 1960s, the last deep mine (Brusselton Colliery; NZ 207 249, which mined to $144 \mathrm{~m}$ depth below the $\sim 210 \mathrm{~m}$ land surface; http://www.dmm.org.uk/shafts/b017-01.htm) closing in June 1968. Farther east, Mainsforth Colliery in Ferryhill ([NZ 307 316]), which mined to the Brockwell seam at -258 m O.D. (342 $\mathrm{m}$ below the $84 \mathrm{~m}$ O.D. land surface), closed in December 1968 (http://www.dmm.org.uk/shaftsm/m001-01.htm). On its closure, the workings were allowed to flood to -175 m O.D. [52]. However, dewatering in the Bishop Auckland area and at Mainsforth persisted to protect Fishburn Colliery (NZ 361 318), the last south of the Butterknowle Fault, until the latter closed in November 1973. Fishburn Colliery was located at $98.6 \mathrm{~m}$ O.D. and mined seams between the Harvey at $132 \mathrm{~m}$ depth and the Brockwell, $\sim 110 \mathrm{~m}$ lower; it thus required dewatering to $\sim 140 \mathrm{~m}$ O.D. At this time, the Permian Zechstein Group rocks (which overlie the PCMG in the area east of Bishop Auckland; Figs 3, 4) contained a perched water table, the relatively impermeable Marl Slate Formation at their base limiting downward infiltration into the dewatered PCMG rocks (e.g., $[60,64,65,66,67])$. Following the closure of Fishburn Colliery, dewatering was discontinued in the Bishop Auckland area and the Mainsforth workings were allowed to flood to $\sim 40 \mathrm{~m}$ O.D. [52]. The water table quickly rose to the $\sim 70 \mathrm{~m}$ O.D. level of the River Wear near Bishop Auckland, resulting in discharge of contaminated minewater into the river at Broken Bank (NZ 197 295), which began in the mid-1970s (e.g., [60]). By the mid-1980s the water table had rebounded to $103 \mathrm{~m}$ O.D., $40 \mathrm{~m}$ below the land surface, at the Woodhouses observation shaft (at NZ 189 281) (e.g., [65,68]) and at the former Tindale Colliery in St Helen Auckland (NZ 197 269; 100 m O.D.) (e.g., [64]). By the 1990s the water table had reached the land surface over much of the region, for instance around Brusselton Farm (NZ 203 255; 150 m O.D.), but remained up to $\sim 100 \mathrm{~m}$ below the land surface in localities farther south, for instance around Bildershaw (NZ 201 242; 200 m O.D.) [65]. Water now seeps from the high ground in this latter area, indicating recovery of the water table following the end of dewatering.

North of the Butterknowle Fault, there was a corresponding history of mine closures in the mid20th century, the last mines in the area SW of Durham closing in the late 1960s (Brancepeth Colliery; NZ 205 357, where the Brockwell seam was mined at $88 \mathrm{~m}$ depth below the $119 \mathrm{~m}$ O.D. land surface http://www.dmm.org.uk/colliery/b015.htm closing in July 1967; Brandon Colliery; NZ 245 400; mined to $125 \mathrm{~m}$ below the $104 \mathrm{~m}$ O.D. land surface; http://www.dmm.org.uk/shafts/b012-01.htm closing in March 1968). Like farther south, it was necessary to maintain dewatering to protect the mines that were still operational farther east (e.g., [64]); pumping stations thus continued to operate until the 1990s, the situation during this span of time being summarized by Harrison et al. [68]. Pumping stations near Bishop Auckland thus included Vinovium (NZ 210 321), maintaining the water table at $13.7 \mathrm{~m}$ O.D., $51 \mathrm{~m}$ below the land surface, and Page Bank (NZ 231 358), maintaining it at $13.3 \mathrm{~m}$ O.D., $39.5 \mathrm{~m}$ below the land surface. Following the ending of deep mining in the Durham coalfield in 1993, 
some of these pumping stations have remained in operation to maintain the water table below the land surface to mitigate pollution, but at a reduced rate, so the water table has risen close to the land surface (e.g., [19]); pumping at Vinovium has been discontinued.

\section{Structural analysis}

The throw on the Butterknowle Fault within the PCMG is $130-160 \mathrm{~m}$ between Woodland and Toft Hill (Fig. 4) [37]. The throw increases eastward to $210 \mathrm{~m}$ north of West Auckland [37] and to $\sim 250 \mathrm{~m}$ farther east [69]. For much of the length of the Butterknowle Fault, beds of the PCMG dip relatively steeply towards it in its hanging-wall. An anticline axis follows this fault at a distance of $\sim 1 \mathrm{~km}$, then a syncline axis at $\sim 3 \mathrm{~km}$ (Figs 6(a), (b)). The tilting adjacent to the fault and the flanking anticline die out westward north of Cockfield (respectively, circa NZ 132270 and NZ 129 253), the former near the point where the Wham Fault splays from the Butterknowle Fault (Fig. 4), the syncline dying out farther east near Evenwood (circa NZ 164 250) [37,50]. As Fig. 4 also indicates, the western limit of these structures coincides with the eastern end of the Wigglesworth Fault, oriented subparallel to the Butterknowle Fault, suggesting a significant change to the geometry of normal faulting in this vicinity. Some $20 \mathrm{~km}$ farther west, the Wigglesworth Fault merges with the Staindrop Fault to form the Lunedale Fault, with which the Butterknowle Fault itself merges farther west at Eggleston (Fig. 3). Even farther west, the Lunedale Fault passes end-on into the Closehouse Fault, which forms the southern boundary of the western part of the Alston Block (Figs. 2, 3).

East of the PCMG outcrop, beneath the Permian Zechstein Group cover, the geometry of the anticline and syncline that parallel the Butterknowle Fault are well resolved from mining records including exploratory drillings (e.g., [70]; Fig. 6(b),(c)), being traceable as far east as Station Town (circa NZ 410 340; Fig. 6(c)). These features, which thus follow the Butterknowle Fault for $>30 \mathrm{~km}$, have long been recognized. For example, Hickling [71] referred to them as 'E.-W. elongated domes and basins', whereas Price [72] called them 'an anticline and complementary syncline', also inferring that these structures might be of some significance for the overall geometry of the fault. Other workers (e.g., $[37,70,73]$ ) have also noted that the axes of these folds follow the Butterknowle Fault at distances of $\sim 1$ and $\sim 3 \mathrm{~km}$, and that their geometries are well-constrained.

Folding parallel to normal faults in this study region has been attributed by many authors (e.g., [39]) to 'fault drag' accompanying Variscan reactivation in a reverse-faulting sense. Some structures, such as that in Fig. 5, are indeed readily explicable in such terms. This phase of deformation is nowadays assigned to the Westphalian C ( 307-304 Ma) and the Stephanian (304-299 Ma) stages of the Silesian (e.g., [74]). Dunham [75] summarized the evidence pertaining to the Butterknowle Fault thus: 'Magraw, Clarke and Smith (1963) established that both the Butterknowle Fault and the folding adjacent to it affect Permian and Coal Measures strata in the neighbourhood of Ferryhill but displacement and fold amplitudes are substantially greater in the Carboniferous, proving renewal of movement.' This evidence indicates that, with the exception of minor deformation, the extensional reactivation of the Butterknowle Fault and the associated folding occurred before the Permian Zechstein Group rocks were laid down. Collier [76] reached an equivalent conclusion, associating this phase of Early Permian extension (between the Variscan Orogeny at $300 \mathrm{Ma}$ and the start of deposition of the Zechstein Group at $240 \mathrm{Ma}$ ) with the incipient rifting in the Mesozoic North Sea extensional basin (cf. [77,78]). The continuity of the Zechstein Group across the Butterknowle Fault (Figs 6(b),(c)) is consistent with this timing. Some normal faults in this region have evidently significantly offset the base of the Zechstein Group, the best-known example being the exposure of the Ninety Fathom Fault in the foreshore at Cullercoats (south of Whitley Bay, circa NZ 370 720; Fig. 3). Here, the downthrow is $260 \mathrm{~m}$ in the PCMG rocks and $\sim 90 \mathrm{~m}$ at the base of the Permian sediments (the Mid-Permian Yellow Sand Formation, which underlies the Zechstein Group) [76,79]. However, the evidence of faulting at this site shows a significant upward decrease into the Zechstein Group [79], suggesting that extensional reactivation of the Ninety Fathom Fault may have ceased not long after the start of its deposition. At some localities in eastern County Durham, the Butterknowle Fault likewise offsets the base of the Zechstein Group by tens of metres, with larger-magnitude slip on the subparallel Hartlepool Fault (Fig. 6(c)). Recognition of Early Permian extension suggests an 
association with the region's Early Permian magmatism, including intrusion of the Great Whin Sill, whose chronology has already been discussed.

To explore this topic, we have undertaken structural modelling after White et al. [80]. This technique allows for calculation of the geometry of fault that can account for an observed pattern of tilting or warping of any bed in its hanging-wall, subject to the assumptions that the footwall remains undeformed and the hanging-wall deforms as a result of a constant fault heave $\mathrm{H}$ combined with distributed simple shear at a constant angle $\theta$ to the vertical. This technique does not reveal any component of strike-slip accompanying extension; the Early Permian reactivation of the Ninety Fathom Fault was accompanied by significant right-lateral slip (e.g., [76,79]), so a similar component can be anticipated on the Butterknowle Fault, given its similar orientation (Fig. 2). The Brockwell coal seam was chosen as the bed to be analyzed, its disposition being digitized from Fig. 6(a). Depths of this coal seam in mine workings near the profile in Fig. 6(a) were extracted from mining records (Table 1) to confirm the accuracy of this profile. In the SE part of Fig. 6(a) the Brockwell seam had been lost to erosion prior to deposition of the Zechstein Group; for this part of the section we use the disposition of the Quarterburn Marine Band, assuming this maintains a constant depth below the Brockwell seam. For this analysis the Butterknowle Fault is assumed to maintain a uniform strike of $\mathrm{N} 62^{\circ} \mathrm{E}-\mathrm{S} 62^{\circ} \mathrm{W}$, the profile from Fig. 6 (a) being projected perpendicular to this. However, because Fig. 6(a) has an overall geometry that is oblique to the fault (Fig. 4), this analysis will estimate a composite geometry for this fault, reflecting an ensemble of localities ranging from the vicinity of Bishop Auckland to points $\sim 4 \mathrm{~km}$ farther WSW.

Figure 10(a) illustrates a first attempt at this modelling. It implies that the decreasing dip of the Brockwell seam within $\sim 1 \mathrm{~km}$ of the 'Castle Fault' arises because the fault flattens to subhorizontal dip near the top of the underlying basement. The adjacent anticline indicates that the fault subsequently steepens at a point close to the footwall cutoff of the main Butterknowle Fault. This solution also indicates that at depth this fault steepens to the $\sim 50^{\circ}$ dip of the footwall escarpment of this fault, estimated by Chadwick et al. [11], and remains planar at this dip to a depth of at least $\sim 5 \mathrm{~km}$. This solution implies that, rather than the Castle Fault and main Butterknowle Fault being separate subparallel structures $\sim 1.5 \mathrm{~km}$ apart, the former accommodated the Early Permian reactivation of the latter, the resulting displacement being 'refracted' across the intervening distance. The resulting geometry accounts for the form of the anticline parallel to the Butterknowle Fault and the northern limb of the associated 'complementary syncline'.

However, this solution does not account for the dip of the southern limb of the 'complementary syncline'. We thus investigated the possibility that this mismatch might arise by compaction of the underlying thick sediment, and is thus unrelated to the geometry of the bounding fault, but found this not to be a feasible explanation. We therefore infer that this dip developed before the Early Permian reactivation of the Ninety Fathom Fault, as a result of upwarping of the area to the south resulting from crustal shortening and associated folding during the Variscan orogeny, as is evident from the regional context (e.g., [72,81]; cf. Fig. 5).

We infer from this analysis that a small component of extensional reactivation of the Butterknowle Fault, amounting to $\sim 60 \mathrm{~m}$ of heave and $\sim 250 \mathrm{~m}$ of throw in the Bishop Auckland area, occurred in the Early Permian, after the extant PCMG rocks were deposited but before the folding thus produced was erosionally truncated by the 'Variscan Unconformity' before deposition of the overlying Permian sediments. At depth, this extension was accommodated on the pre-existing fault, but above its footwall cutoff a new fault developed, transecting the PCMG rocks (plus any overlying sediments, laid down before this phase of extension, but subsequently lost to erosion, before the Permian sedimentation). Based on Fig. 10(a), we suggest that the fault that developed at this time had a 'contractional dip relay' (e.g., [82]) or 'ramp-flat-ramp' (e.g., [83]) geometry. Many studies have identified outcrop-scale instances where normal faulting has propagated upward into layered sequences with such a geometry, or have analyzed such behaviour numerically or via laboratory experiments (e.g., [84,85,86,87,88,89,90,91]). Kilometre-scale examples, akin to this tentative 
Table 1: Mining data recording the disposition of the Brockwell coal seam

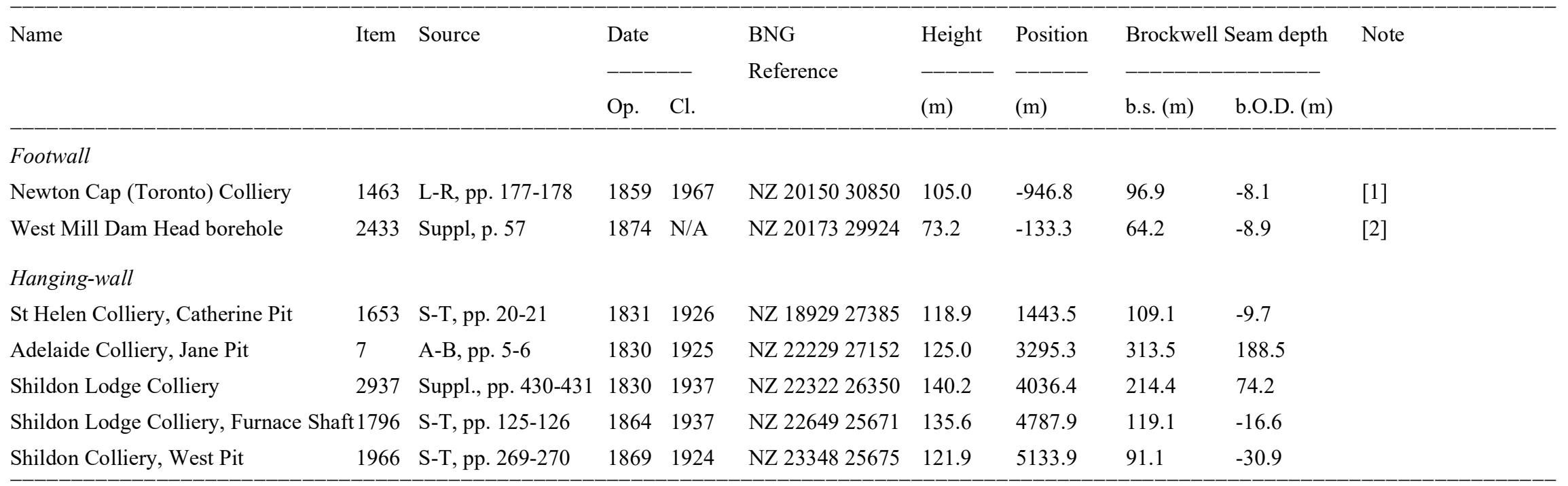

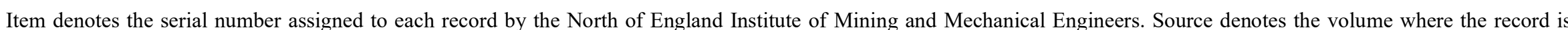

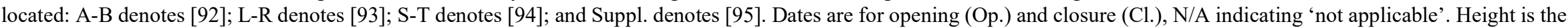

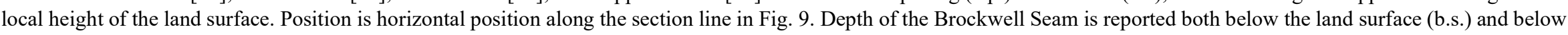

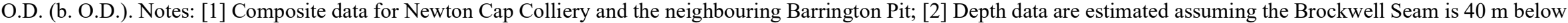
the Busty Seam.

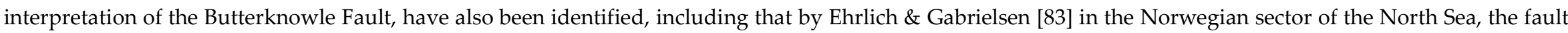

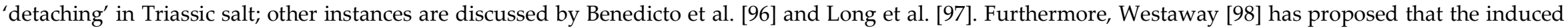

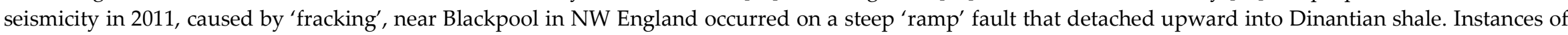

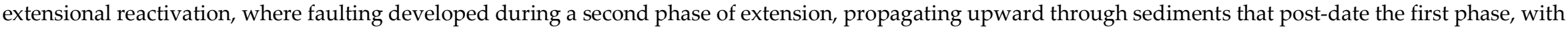
geometrical similarities to the present proposal, have also been recognized elsewhere (e.g., [99,100]).

Informed by this ensemble of examples, we attribute the development of the subhorizontal 'flat' to the weakness of the shale-dominated lower part of the

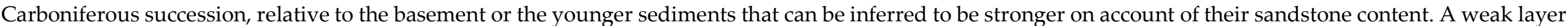

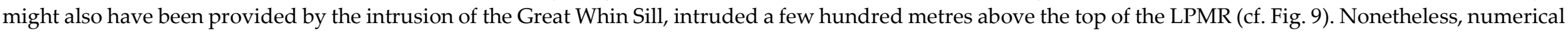




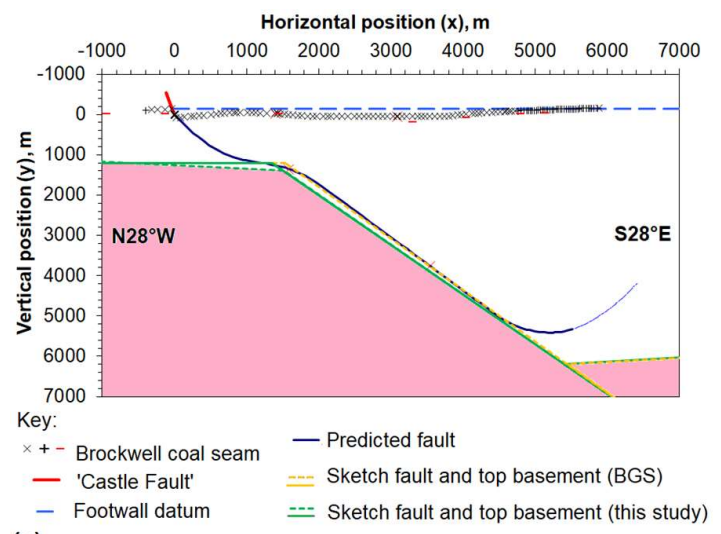

(a)

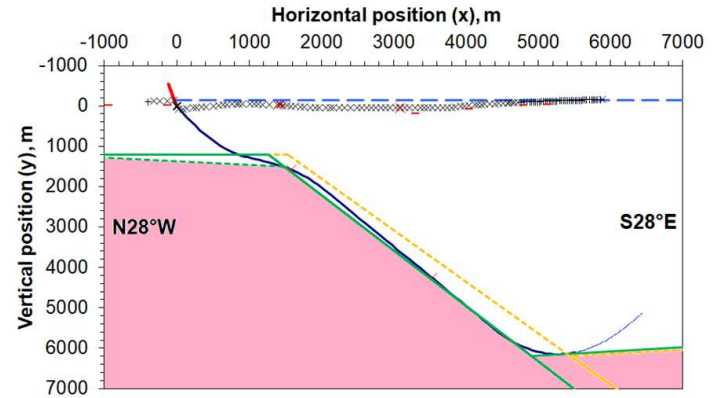

(b)

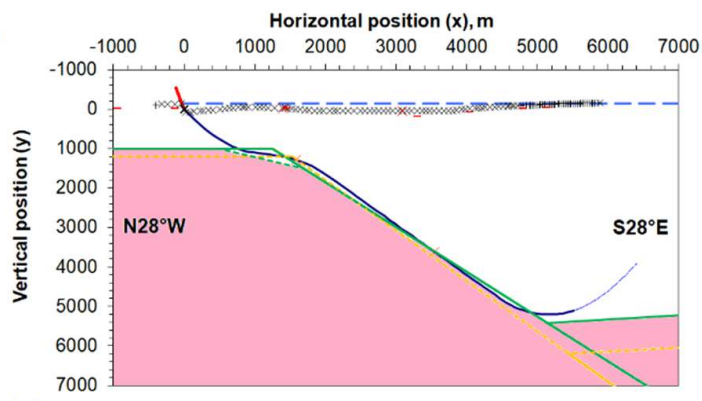

(c)

Figure 10. Structural modelling after White et al. [80]. Observational data for the disposition of the Brockwell coal seam, from Fig. 6(a) and Table 1, have been projected onto a section line oriented $\mathrm{N} 28^{\circ} \mathrm{W}-\mathrm{S} 28^{\circ} \mathrm{E}$, with horizontal position $\mathrm{x}$ measured from zero at the surface trace of the Butterknowle Fault at NZ 17724 28410. The different symbols for the Brockwell coal seam indicate, in order, positions estimated directly from Fig. 6(a), from Table 1, and from the disposition of the Quarterburn Marine Band as depicted in Fig. 6(a). The 'BGS' sketch profile for the fault and top basement is from Chadwick et al. [11] (Fig. 2): its footwall cutoff is NZ 1844727050 or $x=1540 \mathrm{~m}$, the fault surface plunging from depth z (below sea-level) $1200 \mathrm{~m}$ to $6200 \mathrm{~m}$ in $3.9 \mathrm{~km}$ horizontal distance, at a dip of $52^{\circ}$, and plotted in the same position relative to the 'Castle Fault' as in Fig. 2. (a) Initial solution, assuming $62.3 \mathrm{~m}$ of heave (consistent with $250 \mathrm{~m}$ of throw and a $76^{\circ}$ dip of the fault at the surface), with distributed simple shear in the hanging wall inclined at $\theta=-7.2^{\circ}$ (i.e., $7.2^{\circ}$ from the vertical in the syn-thetic sense). The associated planar sketch profile for the fault surface, to approximate this model prediction, is drawn for a footwall cutoff at $\mathrm{z}=1200 \mathrm{~m}$ and $\mathrm{x}=1356 \mathrm{~m}$ (corresponding to NZ 1836127213 ), with a dip of 51 ${ }^{\circ}$. (b) Alternative solution, assuming the same heave, throw and surface dip of the fault, with distributed simple shear in the hanging wall inclined at $\theta=-6.2^{\circ}$. The associated planar sketch profile for the fault surface is drawn for a footwall cutoff at $\mathrm{z}=1200 \mathrm{~m}$ and $\mathrm{x}=1270 \mathrm{~m}$ (corresponding to NZ 18320 27289), with a dip of $54^{\circ}$. (c) Alternative solution, again assuming the same heave, throw and surface dip of the fault, consistent with our 3-D gravity modelling along the projected section line in Fig. 13 . The top of the LPMR is downthrown from a depth of $1001 \mathrm{~m}$ at the footwall cutoff at $\mathrm{x}=1248 \mathrm{~m}$ (NZ 18268 27387 ) to $5422 \mathrm{~m}$ at the hanging-wall cutoff at $\mathrm{x}=5147 \mathrm{~m}$ (NZ 2009923944 ), at a dip of $49^{\circ}$. For this model fit the distributed simple shear in the hanging wall is inclined at $\theta=-7.5^{\circ}$; as illustrated, this requires an erosional 'bevel' by $\sim 400 \mathrm{~m}$ of the top of the LPMR in the footwall. See text for discussion.

simulations (e.g., [90]) predict that the geometry of such structures is sensitive to local conditions (state of stress, depth of burial, rock rheologies, etc); we thus make no attempt to quantitatively relate the $\sim 1 \mathrm{~km}$ downdip extent of the resulting 'detachment' above the basement to such conditions (although we suspect that this length may relate to the thickness of the weak layer). This analysis implies that the 'Castle Fault' does not cut the underlying basement at a steep angle, providing an alternative scenario to that previously proposed $[8,11]$, potentially testable by our gravity survey. 


\section{Gravity survey}

The general principles of gravity surveying are explained in textbooks (e.g., [101,102]). We only discuss site-specific or project-specific aspects.

\subsection{Design}

Figure 6(a) illustrates $250 \mathrm{~m}$ throw and $\sim 75^{\circ}$ dip on the Butterknowle Fault near Bishop Auckland. The steep dip is as expected for post-depositional normal faults in Carboniferous 'Coal Measures' rocks [103]. To ascertain the first-order pattern of Bouguer gravity anomalies $\Delta \mathrm{g}$ in this locality, we first consulted the Tully and Howell map [104], which shows $\Delta \mathrm{g}$ decreasing NNW-SSE from +2 mgal $\sim 1 \mathrm{~km}$ NNW of Bishop Auckland (circa NZ 200310 ) to -5 mgal $\sim 5 \mathrm{~km}$ farther SSE at Shildon (NZ 230 270). To first order, this variation is explicable as a consequence of the sedimentary fill in the Stainmore Basin having lower density than the LPMR beneath the Alston Block (cf. [14]). A second effect evident on this map [104] is the northwestward decrease in $\Delta \mathrm{g}$ beyond points $>\sim 5 \mathrm{~km}$ NW of Bishop Auckland, for example beyond Willington (NZ 190 350). This aspect is readily explicable given the density contract between the LPMR and the Weardale Granite. Kimbell et al. [17] placed the SE margin of this pluton beneath Crook (circa NZ 175 350).

We next obtained from BGS, in spreadsheet format, their gravity dataset covering the present study region (modified as file S1). The listing for each data point includes its BNG reference, height $\mathrm{h}$, free air gravity anomaly $\Delta \mathrm{g}_{\mathrm{F}}$, terrain correction $\Delta \mathrm{g}_{\mathrm{T}}$, and Bouguer correction $\Delta \mathrm{g}_{\mathrm{B}}$. We thus noted that $\Delta \mathrm{g}_{\mathrm{T}}$ and $\Delta \mathrm{g}$ в were calculated using a rock density of $2700 \mathrm{~kg} \mathrm{~m}^{-3}$. This is a standard value used in routine processing of gravity data, but is not appropriate in the present study region as the rocks between sea-level and the land surface are of the PCMG (Fig. 4) for which a $\sim 2500 \mathrm{~kg} \mathrm{~m}^{-3}$ density is appropriate (e.g., [14]). We thus recalculated the BGS values of $\Delta \mathrm{g}_{\mathrm{T}}$ and $\Delta \mathrm{g}_{\mathrm{B}}$, multiplying them by this ratio of densities, then recalculated $\Delta \mathrm{g}$ as

$$
\Delta \mathrm{g} \quad=\quad \Delta \mathrm{g}_{\mathrm{F}}-\Delta \mathrm{g}_{\mathrm{B}}+\Delta \mathrm{g}_{\mathrm{T}}
$$

using the revised values for $\Delta \mathrm{g}_{\mathrm{T}}$ and $\Delta \mathrm{g}_{\mathrm{B}}$. Changing the 'Bouguer density' thus, by $-200 \mathrm{~kg} \mathrm{~m}^{-3}$, increases $\Delta \mathrm{g}$ by $\sim 0.8 \mathrm{mgal}$ for each hundred metres of height. Since points within the Alston Block are typically higher in the landscape than points in the Stainmore Basin, this adjustment has a significant effect on the overall pattern of Bouguer anomalies.

To make a preliminary assessment we used the standard slab formula, for the Bouguer anomaly $\Delta \mathrm{g}$ caused by a slab of density contrast $\Delta \rho$, located between depths $\mathrm{z}_{1}$ and $\mathrm{z}_{2}$, whose edge dips at angle $\alpha$ and projects to the Earth's surface ( $\mathrm{z}=0$ ) at horizontal position $\mathrm{x}=0$,

$$
\Delta \mathrm{g}(\mathrm{x})=2 \mathrm{G} \Delta \rho\left(\left(\mathrm{z}_{2}-\mathrm{Z}_{1}\right) \pi / 2+\left(\mathrm{z}_{2} \theta_{2}-\mathrm{z}_{1} \theta_{1}\right)+\mathrm{x}\left(\theta_{2}-\theta_{1}\right) \sin (\alpha) \cos (\alpha)+\mathrm{x} \sin ^{2}(\alpha) \ln \left(\mathrm{r}_{2} / \mathrm{r}_{1}\right)\right),
$$

where

$$
\begin{array}{ll}
\mathrm{ri}_{\mathrm{i}} & =\sqrt{ }\left((\mathrm{x}+\mathrm{zi} \cot (\alpha))^{2}+\mathrm{zi}^{2}\right) \quad(\mathrm{i}=1,2), \\
\theta_{\mathrm{i}} & =\arctan ((\mathrm{x}+\mathrm{zi} \cot (\alpha)) / \mathrm{zi}) \quad(\mathrm{i}=1,2),
\end{array}
$$

and $\mathrm{G}$ is the gravitational constant ([102]; equation (2.69), p. 42). For $\alpha=90^{\circ}$, (4) simplifies to

$$
\Delta \mathrm{g}(\mathrm{x})=2 \mathrm{G} \Delta \rho\left(\left(\mathrm{z}_{2}-\mathrm{Z}_{1}\right) \pi / 2+\left(\mathrm{z}_{2} \theta_{2}-\mathrm{z}_{1} \theta_{1}\right)+\mathrm{x}\left(\theta_{2}-\theta_{1}\right) \sin (\alpha) \cos (\alpha)+\mathrm{x} \ln \left(\mathrm{r}_{2} / \mathrm{r}_{1}\right)\right)
$$

([102]; equation (2.70), p. 43). With $\mathrm{z}_{2}-\mathrm{Z}_{1}<<\mathrm{z}_{1}$, (5) simplifies to the more familiar 'thin sheet' formula

$$
\Delta \mathrm{g}=2 \mathrm{G}\left(\mathrm{z}_{2}-\mathrm{z}_{1}\right) \Delta \rho\left(\pi / 2+\arctan \left(2 \mathrm{x} /\left(\mathrm{z}_{2}+\mathrm{Z}_{1}\right)\right)\right)
$$


([102]; equation (2.67), p. 40). In turn, in the limit of $x \rightarrow \infty$ (6) tends to the simpler formula for an infinite slab of thickness $\Delta \mathrm{h}=\mathrm{Z} 2-\mathrm{Z} 1$,

$\Delta \mathrm{g} \quad=\quad 2 \pi \mathrm{G} \Delta \mathrm{h} \Delta \rho \quad$

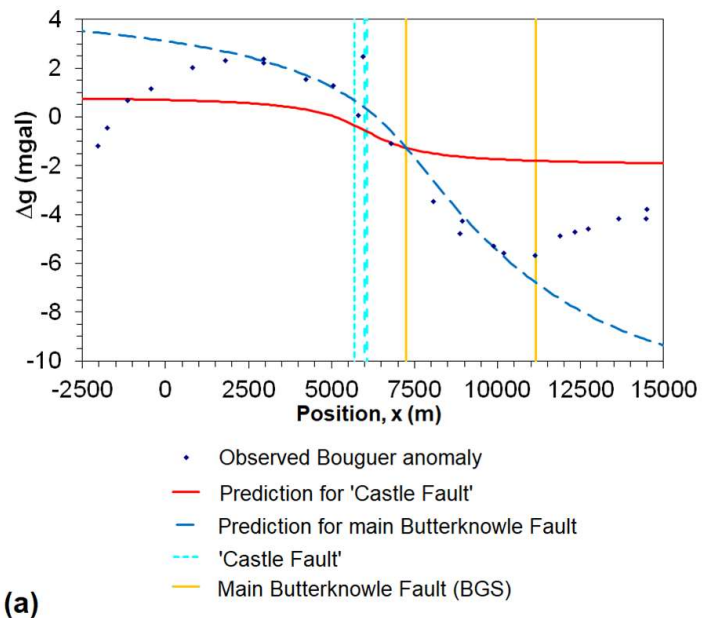

(a)

Figure 11. Preliminary 2-D gravity modelling along the $\mathrm{N} 28^{\circ} \mathrm{W}-\mathrm{S} 28^{\circ} \mathrm{E}$ cross-section depicted in Fig. 4 , with horizontal position $x$ measured from NZ 1800035000 and vertical position measured downward below O.D. Observed gravity points are from the BGS dataset, located within $1 \mathrm{~km}$ of this section line and corrected for a Bouguer density of $2500 \mathrm{~kg} \mathrm{~m}^{-3}$ as described in the text (Supplementary file S1). Note the mismatch between adjacent gravity points NZ-23C22 (NZ 21160 30100, $0.06 \mathrm{mgal}$ ) and NZ23C19 (NZ 21190 29960, $2.47 \mathrm{mgal}$ ), which are 140 m apart; given the overall pattern, point NZ-23C19 is evidently 'duff'. (a) Bouguer anomalies calculated for the 'Castle Fault' and main Butterknowle Fault using equation (2). Calculation for the 'Castle Fault' assumes $\Delta \rho=-280 \mathrm{~kg} \mathrm{~m}^{-3}, \mathrm{z}_{1}=1200 \mathrm{~m}, \mathrm{z} 2=1450 \mathrm{~m}$, and $\alpha=104^{\circ} . \Delta g_{C}=0.9 \mathrm{mgal}$ has been added to the calculated values to facilitate alignment of the prediction with the observed values. Calculation for the main Butterknowle Fault assumes $\Delta \rho=-85 \mathrm{~kg} \mathrm{~m}^{-3}, \mathrm{z}_{1}=1200 \mathrm{~m}, \mathrm{z}_{2}=6200 \mathrm{~m}, \alpha=128^{\circ}$, and $\Delta \mathrm{gc}_{\mathrm{c}}=5.2 \mathrm{mgal}$. This solution corresponds to Fig. 10 (a). (b) Alternative calculations, again using equation (2). Calculation for the 'Castle Fault' is the same as in (a). Calculation for the main Butterknowle Fault assumes $\Delta \rho=-80 \mathrm{~kg} \mathrm{~m}^{-3}, \mathrm{z}_{1}=1200 \mathrm{~m}, \mathrm{z} 2=6200 \mathrm{~m}$, $\alpha=126^{\circ}$, and $\Delta \mathrm{gc}=5.2 \mathrm{mgal}$. This solution corresponds to Fig. $10(\mathrm{~b})$.

To apply this analysis we prepared a cross-section oriented at an azimuth of $152^{\circ}\left(\mathrm{N} 28^{\circ} \mathrm{W}-\mathrm{S} 28^{\circ} \mathrm{E}\right.$, parallel to the cross-section in Fig. 10), perpendicular to the Butterknowle Fault at Bishop Auckland (see Fig. 4 for location). This profile crosses the surface trace of the 'Castle Fault' in the centre of Bishop Auckland (at NZ 20663 29991, at 110 m O.D.). Assuming a 76 dip (see above), this fault projects to O.D. (at NZ 2067629967 ) at $x=5700 \mathrm{~m}$. In Fig. 2 the line of the 'Castle Fault', depicting its notional offset of the top of the LPMR circa $1200 \mathrm{~m}$ below O.D., also passes through this point (i.e., through NZ 20676 29967), indicating that Chadwick et al. [11] assumed this fault to be subvertical when preparing this diagram. Conversely, if this fault maintained a $76^{\circ} \mathrm{dip}$, it would project to $1200 \mathrm{~m}$ below O.D. at $\mathrm{x}=5999 \mathrm{~m}$ (at NZ 20816 29713) and to $1450 \mathrm{~m}$ below O.D. at $\mathrm{x}=6061 \mathrm{~m}$ (at NZ 20846 29648). Along the same section line, the main Butterknowle Fault projects (from Fig. 2) with its footwall cutoff at $x=7236 \mathrm{~m}$ (at NZ 21397 28611) and its hanging-wall cutoff at $x=11197 \mathrm{~m}$ (at NZ 23231 25162); given the $5000 \mathrm{~m}$ change in depth (Fig. 2), the $3906 \mathrm{~m}$ distance between these points indicates a $52^{\circ}$ dip of this escarpment (cf. [11]).

Figure 11 shows attempts at modelling the resulting cross-section using equation (2). A density of $2780 \mathrm{~kg} \mathrm{~m}^{-3}$ has been assumed for the LPMR, after Kimbell et al. [17] whereas $2500 \mathrm{~kg} \mathrm{~m}^{-3}$ is appropriate for the PCMG rocks, as already noted. Figure 11(a) shows an initial solution in which the 'Castle Fault' is assumed to be planar with a $76^{\circ}$ dip and to offset the LPMR with a throw of $250 \mathrm{~m}$, the associated density contrast being $280 \mathrm{~kg} \mathrm{~m}^{-3}$. The Bouguer anomaly thus predicted has an 
amplitude of $\sim 2 \mathrm{mgal}$ of which $\sim 1 \mathrm{mgal}$ is concentrated within $\sim 1 \mathrm{~km}$ of the fault. However, there is no feature of the BGS observational gravity dataset to reveal the Bouguer anomaly indicated for the 'Castle Fault'; nonetheless, few data points occur within the $\sim 1 \mathrm{~km}$ distance range on either side of this fault where this predicted anomaly is concentrated. It is thus evident that to resolve whether this fault cuts the basement or not in this vicinity requires significantly denser coverage by gravity measurements, and that these measurements must be accurate to tenths of a milligal. These considerations informed the design of our gravity survey (see below).

To facilitate this initial prediction, the main Butterknowle Fault has been placed as depicted in Fig. 2, with $\mathrm{x}_{\mathrm{o}}=6300 \mathrm{~m}$, a dip of $52^{\circ}$ and a throw of $5000 \mathrm{~m}$; to match the observed pattern of gravity anomalies a density contrast of $85 \mathrm{~kg} \mathrm{~m}^{-3}$ has been adopted, implying an average density of the sedimentary fill in the Stainmore Basin of $2695 \mathrm{~kg} \mathrm{~m}^{-3}$. The resulting Bouguer anomaly can be seen (Fig. 11(a)) to provide a reasonable overall match to trend in the observations above the buried footwall escarpment. However, moving NNW into the footwall, through positions at $x<3000 \mathrm{~m}$, the prediction increasingly overestimates the observed Bouguer anomalies, presumably because this 2-D modelling does not incorporate the gravitational effect of the low-density Weardale Granite (cf. Kimbell et al. [17]). Moving SSE into the hanging-wall, the prediction over-predicts the magnitude of the observed negative Bouguer anomalies, presumably because it does not consider the SSE rise (as shown in Fig. 2) of the top of the high-density LPMR away from the fault. The rise in this contact indicates tilting of the Butterknowle Fault to a shallower-angle dip during extension, this effect being potentially explicable as a consequence of 'rigid domino' rotation of crustal blocks (e.g., Jackson and McKenzie [105]) or distributed vertical simple shear (Westaway and Kusznir [106]). In addition to these unmodelled density variations, we note that several adjacent points indicate lateral variations in Bouguer anomalies parallel to the Butterknowle Fault, demonstrating the need for threedimensional (3-D) modelling. However, a mismatch of $>1$ mgal is evident at the hanging-wall cutoff; this suggests that the true position of this cutoff is farther NNW, indicating that the buried footwall escarpment in Fig. 2 is misplaced.

Figure 11(b) shows an alternative solution. A $5000 \mathrm{~m}$ throw has been retained for the main Butterknowle Fault, but this fault has been moved to $\mathrm{x}_{0}=6100 \mathrm{~m}$, with its dip increased to $54^{\circ}$ and the density contrast reduced to $80 \mathrm{~kg} \mathrm{~m}^{-3}$. As a result of these changes, the footwall and hanging-wall cutoffs adjusted to $x=6972 \mathrm{~m}$ (NZ 21273 28844) and $x=10605 \mathrm{~m}$ (NZ 22979 25637), adjustments NNW by $264 \mathrm{~m}$ and $537 \mathrm{~m}$, respectively. The fit to the observational data is very similar to that in Fig. 11(a), but the NNW adjustment of the hanging-wall cutoff eliminates the mismatch evident in it. Figure 10(b) illustrates structural modelling after White et al. [80], consistent with Fig. 11(b). The fault geometry thus indicated provides a starting point for our detailed gravity analysis (see below).

\subsection{Implementation and analysis}

As noted above, our gravity survey was designed with the main aim of distinguishing between the foregoing scenarios: whether the 'Castle Fault' transects the LPMR at a steep angle beneath Bishop Auckland [11,17]; or whether it is an upper 'ramp', linked to the subsurface buried footwall escarpment via a 'flat' or detachment. From earlier discussion, discrimination of this requires considerable accuracy: our aim was to measure Bouguer gravity anomalies accurate to $0.1 \mathrm{mgal}$ or thereabouts. Furthermore, given previous observations of lateral (strike-parallel) variations in gravity (Fig. 11), we made measurements at a grid of points, rather than along one or more linear profiles, in anticipation of 3-D modelling. This survey area covered $\sim 30 \mathrm{~km}^{2}$, as a rough rectangle with $\sim 5 \mathrm{~km}$ sides oriented WSW-ENE, subparallel to the Butterknowle Fault, and $\sim 6 \mathrm{~km}$ sides in the perpendicular direction, with corners adjoining Vinovia Roman Fort, Middridge, Brusselton and Etherley Grange (Fig. 4). In the NNW-SSE direction this area spans from points $\sim 1 \mathrm{~km} \mathrm{NNW}$ of the 'Castle Fault' to roughly the position identified by Chadwick et al. [11] for the hanging-wall cutoff of the LPMR at the buried footwall escarpment of the main Butterknowle Fault. The pre-existing BGS gravity points in this area (illustrated in Supplementary file S1) are spaced typically one per $\sim 1 \mathrm{~km}^{2}$ of land area, but are unevenly distributed, with 'gaps' of $\geq 3 \mathrm{~km}$ in the south, overlying this buried escarpment. The intention was to survey points with spacing $\sim 100 \mathrm{~m}$ along the line of the 'Castle 
Fault', increasing gradually to $\sim 300 \mathrm{~m}$ and then to $\sim 500 \mathrm{~m}$ in the south of the survey area, where relatively smooth variations in Bouguer anomalies were expected due to the depth of the Butterknowle Fault and where significant access difficulties were anticipated due to the sparse network of roads and public footpaths. Most landowners were happy to grant access, but in the event of refusals points were surveyed along public footpaths that provide rights of way across the land, to mitigate 'gaps' in the network. Fieldwork took place during 25-29 May and 19-23 October 2015 (Supplementary files S2 and S3).

Raw gravity measurements were made using a Lacoste-Romberg gravimeter (Migro-g LaCoste, Lafayette, Colorado). Terrain corrections were estimated using the Hammer [107] procedure, the corrections for the inner zones being noted in the field and those for outer zones determined from large-scale topographic maps. The height of each point was measured in the field using Thales Magellan ProMark3 (Thales Group, Paris, France) GPS equipment, the differential processing being performed using Leica GeoOffice (Leica Geosystems, St Gallen, Switzerland; LGO) software. BNG co-ordinates and provisional heights of points were also measured in the field using a handheld GPS receiver. The differential GPS (dGPS) base station was located in the grounds of Auckland Castle (at NZ 21267 30200), where its internal batteries were connected to the mains electricity supply to enable continuous recharging during operation. This base station was re-visited typically four times a day to repeatedly measure gravity in order to monitor gravimeter drift. Tidal corrections to gravity were calculated using the TSoft (Royal Observatory of Belgium, Brussels [108]) and Micro-g LaCoste QuickTide Pro software packages. Due to the inland location, the tidal corrections were small, never larger in magnitude than $0.1 \mathrm{mgal}$, and closely consistent between software packages; the values obtained from QuickTide Pro were applied to the raw data. The differential height measurements obtained from dGPS were converted to absolute heights using the height of the benchmark on the wall of the Town Hall in Bishop Auckland Market Place (NZ 21164 30097; 95.404 m O.D.); for the majority of points (excluding sites where trees or buildings affected sky visibility) the LGO software yielded differential heights accurate to within millimetres.

In the absence of any absolute gravity points within the survey area (the closest being in Durham, a $>30 \mathrm{~km}$ roundtrip journey away), we did not reference our survey to absolute gravity but instead tied it directly to the existing BGS gravity dataset. This was feasible because many of the BGS gravity points were co-located with Ordnance Survey benchmarks, whose precise locations and surveyed heights were reported on definitive topographic maps. However, it transpired that most of these benchmarks had been destroyed, the walls on which they had been inscribed having been demolished or obscured beneath pebble-dash rendering. A further potential disadvantage of this approach, already noted, is that gravity might well have changed between the times of the BGS gravity measurements and our survey, due to the ending of mine dewatering.

We use equation (7) to estimate these changes to gravity. Thus, flooding a $2 \mathrm{~m}$ high worked coal seam $\left(\Delta \mathrm{h}=2 \mathrm{~m} ; \Delta \rho=1000 \mathrm{~kg} \mathrm{~m}^{-3}\right)$ would increase surface gravity by $\sim 0.084$ mgal. Flooding of a succession of 6 seams, as were worked in many localities, would thus increase surface gravity by $\sim 0.50 \mathrm{mgal}$. The effect of flooding of pore space in sandstone is more difficult to estimate, as the proportion of sandstone in PCMG successions is variable and its porosity highly variable. We take the proportion of sandstone in the PCMG as 40\% after Westaway and Younger [19]. Jones et al. [109] reported the typical porosity of coal measures sandstone samples in the range $5-15 \%$, whereas Monaghan et al. [5] reported 3-23\%. Assuming 15\%, the bulk porosity of the whole succession is $6 \%$; if the saturated bulk density is $2500 \mathrm{~kg} \mathrm{~m}^{-3}$, this makes the mean density of the rock (excluding pore space) $\sim 2600 \mathrm{~kg} \mathrm{~m}^{-3}$ and the unsaturated bulk density $\sim 2440 \mathrm{~kg} \mathrm{~m}^{-3}$. Flooding by $100 \mathrm{~m}$ thus caused $\Delta \rho=60 \mathrm{~kg} \mathrm{~m}^{-3}$, increasing surface gravity by $\sim 0.25 \mathrm{mgal}$. Assuming $20 \%$, making $\Delta \rho=80 \mathrm{~kg} \mathrm{~m}^{-3}$, the effect would be $\sim 0.33 \mathrm{mgal}$. It is thus evident that the end of mine dewatering might have increased gravity by of the order of 1 milligal, but varying across the region due to the different numbers of coal seams worked and different depths of past dewatering in different localities. The BGS gravity dataset provided were not accompanied by date-of-acquisition metadata. However, it can be presumed that the data were used to produce the Tully and Howell gravity map [104], and were thus 
measured no later than the mid-1970s; in accordance with earlier discussion, extensive mine dewatering was in operation in this study region at this time.

Setting aside the possibility of such mismatches for now, two BGS gravity points co-located with benchmarks were readily locatable to potentially tie our data to the BGS dataset: in Bishop Auckland Market Place (BGS gravity point NZ_23C22), 150 $\mathrm{m}$ WSW of the base station and also $150 \mathrm{~m}$ SSE of the surface trace of the 'Castle Fault', and on a house wall on Rutland Avenue, $\sim 1.5 \mathrm{~km}$ south of the town centre (at NZ 20831 28582; BGS gravity point NZ_22A08). Each of these potential 'tie' gravity points was surveyed three times, once in May 2015 and twice in October 2015. The differences in Bouguer gravity anomaly between these two points for our three sets of measurements were 1.18, 1.24 and 1.34 mgal, compared with the 1.14 mgal difference between the BGS values (after correction for Bouguer density), the mean variation between these differences being $0.113 \mathrm{mgal}$. Using equation (6) with $\mathrm{x}=0, \mathrm{z}_{1}=0, \mathrm{z}_{2}=50 \mathrm{~m}$ and $\Delta \rho=80 \mathrm{~kg} \mathrm{~m}^{-3}$, consistent with the water table being $50 \mathrm{~m}$ lower in the area north of the Butterknowle Fault when the BGS data were collected, but the same as at present south of this fault (in accordance with earlier discussion), gives a variation of $0.084 \mathrm{mgal}$, in reasonable agreement. This suggests that it is preferable to use the Rutland Avenue benchmark as the tie point; we use the middle of its three measurements, measured on 23 October 2015, as the tie.

In summary, the workflow for gravity data processing involved the following steps. While in the field we made the raw gravity measurements and GPS signal recordings at each data point, measured co-ordinates using the handheld GPS receiver, and noted height variations to give terrain corrections using Hammer's [107] procedure, returning every 3-4 hours to the base station to record gravimeter drift. Second, after each day in the field, we retrieved the GPS signal recordings from the base station and roving station and processed these data using the LGO software to determine accurate heights of all points, substituting measurements from large-scale maps for the few points where dGPS did not yield reliable results. We next corrected the raw gravity data for gravimeter drift, tide, terrain, and latitude, then used the accurate heights from the dGPS to determine free air and Bouguer corrections, the latter for a density of $2500 \mathrm{~kg} \mathrm{~m}^{-3}$, as already explained. The standard formulae used for latitude, free air, and Bouguer corrections are explained in many textbooks (e.g., [102]). We, finally, applied the latter corrections to the gravity data, to determine Free Air and Bouguer gravity anomalies. The resulting data were merged with those for the pre-existing BGS points (with Bouguer anomalies corrected for a Bouguer density of $2500 \mathrm{~kg} \mathrm{~m}^{-3}$ ) to prepare the dataset listed in Supplementary file S4. This list of points was imported into ERDAS ER Mapper software (Hexagon Geospatial, Norcross, Georgia) and gridded using a triangulation algorithm onto a $10 \mathrm{~km}$ by 10 km square grid (between NZ 1700033000 and NZ 27000 23000; Fig. 4) with 100 m point spacing (Supplementary file S5). The occurrence of gridding artefacts around the edges of this area was minimized by the inclusion of BGS gravity points located outside the area (Fig. 12).

Initial attempts using this procedure revealed significant gridding artefacts, reflecting inconsistencies in the input data. Occasional 'duff' BGS gravity measurements like that identified in Fig. 11, inconsistent by more than 2 mgal relative to neighbouring points, could be readily identified and excluded. More subtle effects were also evident, including abrupt 'edges' between several of our gravity points and BGS points within $\sim 100-200 \mathrm{~m}$, also one BGS point (NZ-22B07, at Middridge) indicating a local gravity 'low', with $\Delta \mathrm{g} \sim 0.4$ mgal less than in all surrounding directions. All these instances noted (Table 2 and Fig. 12) were in the Shildon-Eldon-Middridge area (Fig. 4), in the 'complementary syncline' subparallel to the Butterknowle Fault (Fig. 6(a)). In this vicinity, the formerly mined coal seams (down to the Brockwell Seam; Fig. 6(a)) were relatively deep, so the rise in the water table since the end of mining has been relatively large, up to $\sim 200 \mathrm{~m}$ (given earlier discussion). From this discussion, flooding of $200 \mathrm{~m}$ thickness of rock with $\Delta \rho=60 \mathrm{~kg} \mathrm{~m}^{-3}$, or $12 \mathrm{~m}$ thickness of worked coal seams with $\Delta \rho=1000 \mathrm{~kg} \mathrm{~m}^{-3}$, after the BGS gravity measurements were made, might each account for this difference. After identifying this candidate explanation we were initially puzzled as to why the effect was not more extensive, in particular why the area farther north and west, between Eldon and West Auckland, was unaffected. Stobbs ([110], p. 51) noted that many mines in this area became flooded during the General Strike of 1926, when the coal industry was shut down for more than six months; many collieries thus affected were uneconomic to reopen, so their workings 
were already flooded when the BGS gravity measurements were made. Stobbs ([110], p. 51) indeed reported the creation of a 'huge underground lake' in flooded mineworkings in this area. Data points that are likely to be affected by the ending of mine dewatering are identified in Table 2 and Supplementary file S1 and have been excluded from further analysis; Figs 12 and 13 indicate the Bouguer anomalies after exclusion of these data. We believe this to be the first instance of recognition of measurable changes in gravity associated with the ending of mine dewatering in the UK.

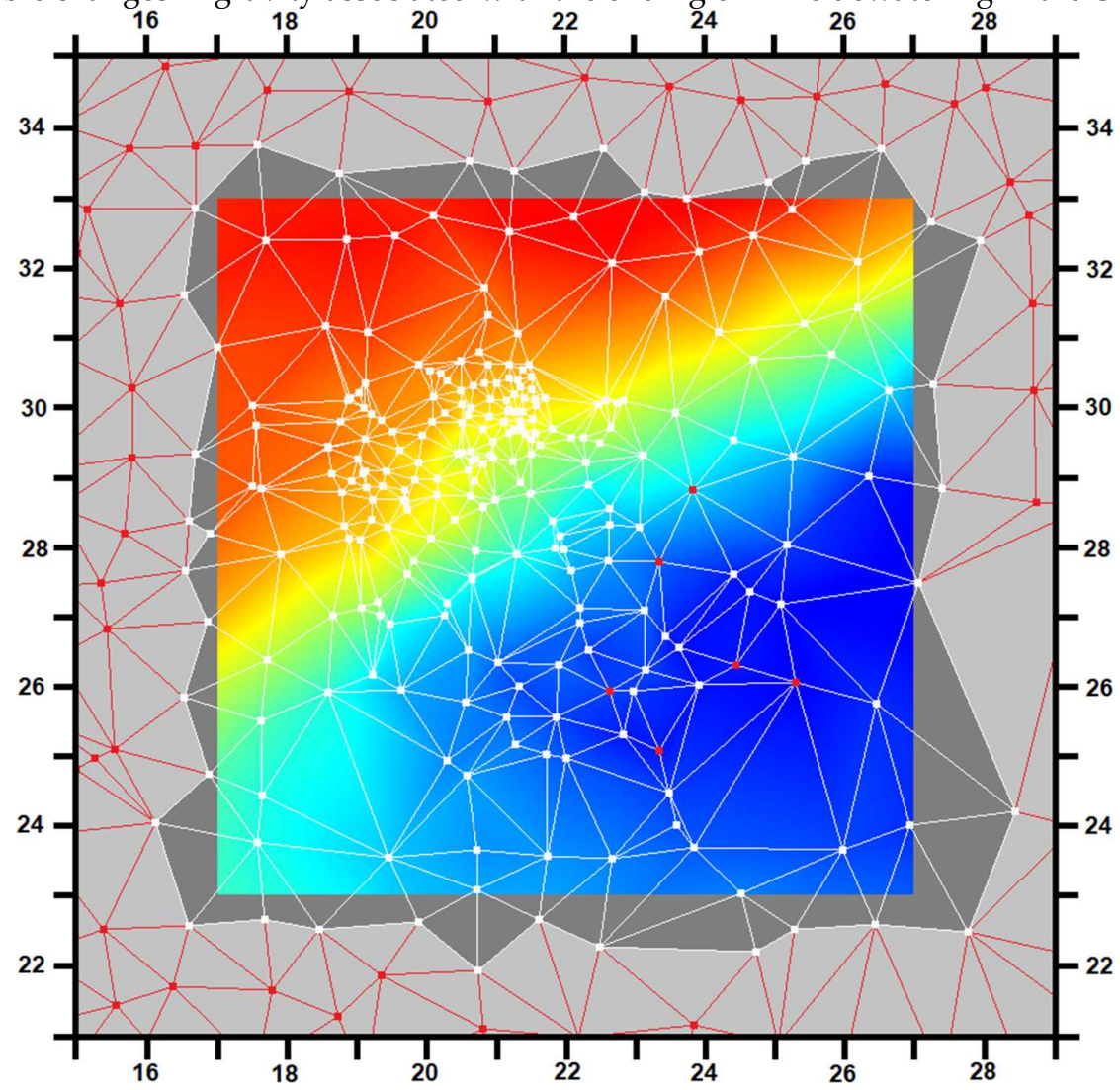

Figure 12. Illustration of the process of gridding the gravity dataset. White squares are gravity points, from our survey and the pre-existing BGS gravity dataset, after removal of inconsistent points. White lines linking these points indicate the triangles joining nearest-neighbour points, determined by the gridding algorithm to enable interpolation of Bouguer anomalies between these points. Colour shading (depicted in more detail in Fig. 13(a)) provides a representation of the lateral variations in the interpolated and gridded Bouguer anomalies, ranging from values as high as $+2.8 \mathrm{mgal}$ (red) to as low as $-5.8 \mathrm{mgal}$ (blue). Dark grey shading illustrates areas surrounding the study area, included to highlight gravity points in this surrounding area that contribute to the gridding of points within the study area. Red lines and points in neighbouring areas with light grey shading were included in the gridding (to avoid edge effects in the study area) but do not contribute to the gridded gravity dataset for of any part of the study area. Shaded points inside the area of interest are listed in Table 2 and indicate significant changes over time in Bouguer anomalies, which we suggest have been caused by rises in the water table linked to the ending of mine dewatering.

\subsection{Gravity modelling}

The gridded dataset generated by ERDAS ER Mapper (Supplementary file S5) was imported into the Noddy 3-D gravity modelling software. This former commercial software package is currently supported for academic use by Tectask, the IUGS commission for structural geology and tectonics (http://www.tectonique.net/tectask/index.php?option=com content\&view=article\&id=23). As a starting point for modelling, we inspected the published solution by Kimbell et al. [17]. These authors were primarily concerned with identifying the shape of the Weardale Granite from its gravity 

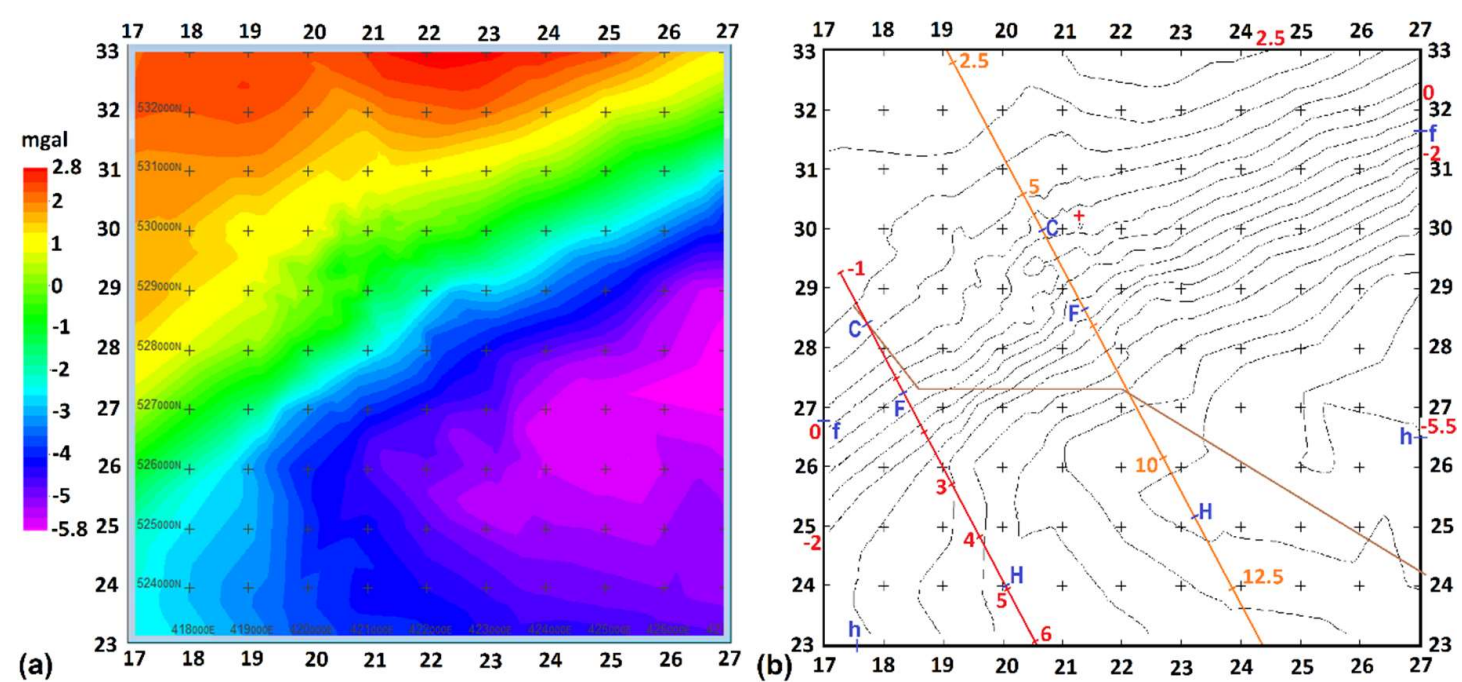

Figure 13. Gridded Bouguer gravity anomaly dataset, prepared as described in the text. (a) depicted using colour-shading. (b) depicted as a contour plot with 0.5 mgal contours, also showing the section lines in Figs 6(a), 10 and 11, the location of Auckland Castle (cross; NZ 21354 31213), and intersections with the surface trace of the Castle Fault, C (NZ 1772428410 and NZ 20662 29983), and with the footwall, F (NZ 1836127213 and NZ 21397 28621), and hanging-wall, H (NZ 2006624006 and NZ 23231 25162), cutoffs of the main Butterknowle Fault (as depicted in Figs 10(b) and 11(b)), based on structural modelling and preliminary gravity modelling. Lower-case letters $f$ and $h$ denote the footwall and hanging-wall cutoffs of the main Butterknowle Fault at the edges of the 3-D gravity model in Fig. 15 (footwall at NZ 1700026769 and NZ 27000 31641; hanging-wall at NZ 1753723000 and NZ 27000 26487).

effect; as already noted, our study area falls within the SE part of theirs. Their analysis first upwardcontinued the pattern of Bouguer anomalies to $1 \mathrm{~km}$ above O.D., then subtracted the gravity effect of the sedimentary column, assuming for each formation a nominal density and the thickness specified by Chadwick et al. [11]. They then applied a correction for large-scale regional variations in deep crustal density, and then modelled the resulting gravity anomaly, assuming uniform densities for the granite and surrounding basement and a uniform depth of the base of the granite. Although their analysis matched the gravity effect near the centre of the granite well, Kimbell et al. [17] reported mismatches between observed and predicted gravity of up to $2 \mathrm{mgal}$ in some areas overlying this granite, and by $>4 \mathrm{mgal}$ around its margins, including in the Stainmore Basin, the root-mean-square mismatch throughout their model area being 1.3 mgal. Evidently, some aspect(s) of their modelling are incorrect; the issue of Bouguer density has already been noted. Others might include the interpretation of sedimentary formations or their assumed densities, or the unexplained 'regional' correction, or the choice of densities for the basement or granite, or the assumption of a uniform depth of the base of the latter. Furthermore, Chadwick et al. [11] did not report the thickness of several of the formations present in the Stainmore Basin, making it unclear what values were used in the Kimbell et al. [17] analysis. In addition, major differences exist between interpretations; for example, in the locality in Fig. 7, Collier [30] reported the base of the sediment $>1 \mathrm{~km}$ deeper than did Chadwick et al. [11], a difference that - on its own - would reduce the predicted gravity by several milligals. Although this particular modification would worsen the mismatch relative to the observations, there are no doubt many other adjustments relative to the Kimbell et al. [17] gravity modelling procedure that might improve the match between data and model predictions.

As a further initial constraint on the modelling, we consider the location of the hanging-wall cutoff of the main Butterknowle Fault. As Fig. 13(b) indicates, the position of this, tentatively deduced from Figs 10(b) and 11(b), closely adjoins the axis of the Bouguer gravity minimum. One might arguably have begun the analysis by assuming that the axis of the Bouguer gravity minimum 
Table 2: Gravity effect of mine dewatering

\begin{tabular}{|c|c|c|c|c|c|c|c|c|}
\hline \multirow[b]{2}{*}{ Name } & \multicolumn{3}{|c|}{ University of Glasgow points } & \multicolumn{3}{|l|}{ BGS points } & \multirow[b]{2}{*}{ Diff. } & \multirow[b]{2}{*}{ Note } \\
\hline & ID & BNG & $\Delta \mathrm{g}$ & ID & BNG & $\Delta \underline{\mathbf{g}}$ & & \\
\hline Eldon & UGBA15-2712 & 2335227777 & -4.596 & NZ-22A13 & 2324027750 & -4.780 & 0.184 & 1 \\
\hline Middridge-Shildon road & UGBA15-2715 & 2445626301 & -5.334 & NZ-22A02 & 2446026320 & -5.781 & 0.447 & 1 \\
\hline Nisa Filling Station, Shildon & UGBA15-2717 & 2335425072 & -5.300 & NZ-22A17 & 2342025270 & -5.682 & 0.382 & 1 \\
\hline Hackworth School, Shildon & UGBA15-2823 & 2263825935 & -4.911 & NZ-22A16 & 2267025950 & -5.584 & 0.673 & 1 \\
\hline Howlish & UGBA15-2918 & 2383928820 & -3.374 & NZ-22A14 & 2385028790 & -3.976 & 0.602 & 1 \\
\hline Middridge & & & & NZ-22B07 & 2531026050 & -5.979 & 0.400 & 2 \\
\hline
\end{tabular}

Notes: 1. BGS point excluded

2. Bouguer anomaly for BGS point modified to reflect the estimated effect of the ending of mine dewatering

marks the greatest thickness of low-density sedimentary fill within the Stainmore Basin and thus indicates the hanging-wall cutoff directly. If so, this cutoff follows a line maybe $\sim 500 \mathrm{~m}$ NNW of that indicated in Fig. 13(b), making the heave of this fault $~ 3100 \mathrm{~m}$ rather than $\sim 3600 \mathrm{~m}$ indicated in Fig. 10(b), which requires the fault to be somewhat steeper or to have a somewhat lower throw than has hitherto been identified. For example, if its throw is $5000 \mathrm{~m}$ then its dip might adjust from $54^{\circ}$ to $58^{\circ}$; alternatively, with dip retained as $54^{\circ}$ its throw would adjust from $\sim 5000 \mathrm{~m}$ to $\sim 4300 \mathrm{~m}$. These considerations provide options to test via our gravity modelling. We note that our 'densification' of coverage of the Middridge-Brusselton area with additional points, filling in 'gaps' in the BGS coverage, significantly improved definition of the axis of the Bouguer gravity low. Had time permitted, more points in the sparsely-covered area farther south (School Aycliffe - Redworth - Bolam; Fig. 4) would have also been beneficial.

The Noddy software requires the development of a model geological history for each study region, from which the predicted Bouguer gravity anomaly is calculated across the grid of points, for comparison with the gridded measurements. The scope for model development is limited to the available range of preprogrammed history 'elements'. Some of these impose limitations on choices of solutions, for example the basic option for defining a fault assumes a planar fault surface with constant dip and displacement. The software thus cannot model the localized variations in the strike or throw of the Butterknowle Fault across the model area, evident for example in Figs 1 and 2. As depicted in these Figures, and taking account of the ENE tilt of the top of the LPMB, the footwall cutoff of the main Butterknowle Fault has an overall strike across this area of $\mathrm{N} 64^{\circ} \mathrm{E}$, slightly more easterly than its $\mathrm{N} 62^{\circ} \mathrm{E}$ strike in the immediate vicinity of Bishop Auckland. The axis of the Bouguer gravity minimum also strikes at N64 ${ }^{\circ} \mathrm{E}$ across the model area (between NZ 180238 and NZ 270 279), indicating a consistent orientation.

As regards densities, we note that much work has adopted $2630 \mathrm{~kg} \mathrm{~m}^{-3}$ for the Weardale Granite and $2780 \mathrm{~kg} \mathrm{~m}^{-3}$ for the LPMR (e.g., [8,17]). Bott [111] reported the density contrast between these lithologies as $150 \mathrm{~kg} \mathrm{~m}^{-3}$, but with a margin of uncertainty of $\pm 50 \mathrm{~kg} \mathrm{~m}^{-3}$. From the compilation of data by Kimbell et al. [8], 2630 $\mathrm{kg} \mathrm{m}^{-3}$ is a reasonable representative value for Caledonian granites in northern England. The Skiddaw Slates, which form the outcrop of LPMR within the Teesdale Inlier [112], have a density very close to $2780 \mathrm{~kg} \mathrm{~m}^{-3}$ in the compilation of data by Kimbell et al. [8]. Woolacott [59] also likened the LPMR reached at the base of the 
Roddymoor borehole to the Skiddaw Slates. However, in the Lake District the outcrop of LPMR is highly diverse; some of it is of the Skiddaw Slates, elsewhere it is of other lithologies with mean densities ranging from 2680 to $2830 \mathrm{~kg} \mathrm{~m}^{-3}$ [8]. For the overlying sediments, Kimbell et al. [17] adopted densities of $2700 \mathrm{~kg} \mathrm{~m}^{-3}$ for the Ravenstonedale Group, $2680 \mathrm{~kg} \mathrm{~m}^{-3}$ for the Alston Formation, $2550 \mathrm{~kg}$ $\mathrm{m}^{-3}$ for the Stainmore Formation and $2500 \mathrm{~kg} \mathrm{~m}^{-3}$ for the PCMG. For the Great Scar Limestone Group they assigned the constituent formations densities between 2550 and $2700 \mathrm{~kg} \mathrm{~m}^{-3}$. These values represent averages of a large number of individual determinations for Lower Carboniferous rock samples as compiled by Kimbell et al. [8]: $2420 \pm 30 \mathrm{~kg} \mathrm{~m}^{-3}$ for sandstones, $2560 \pm 40 \mathrm{~kg} \mathrm{~m}^{-3}$ for shales, and $2680 \pm 20 \mathrm{~kg} \mathrm{~m}^{-3}$ for limestones. Many workers have adopted representative densities for the continental crust of circa $2700 \mathrm{~kg} \mathrm{~m}^{-3}$; for example, the advanced gravity/geoid model by Pavlis et al. [113] uses $2670 \mathrm{~kg} \mathrm{~m}^{-3}$. The present modelling will be expressed in terms of density differences $\Delta \rho$ relative to reference values of this order (Table 3 ).

Table 3: Density model

\begin{tabular}{|c|c|c|c|}
\hline Unit & $\begin{array}{l}\Delta \rho \\
\left(\mathrm{kg} \mathrm{m}^{-3}\right)\end{array}$ & $\begin{array}{l}\text { Thickness } \\
\text { (m) }\end{array}$ & Note \\
\hline Cleveland Dyke & +140 & 50 & [1] \\
\hline PCMG & -200 & 850 & \\
\hline Stainmore Formation & -120 & 300 & \\
\hline Alston Formation & +50 & 700 & \\
\hline Great Scar Limestone Group & -180 & 3000 & \\
\hline Ravenstonedale Group & -180 & 3000 & \\
\hline Weardale Granite & -50 & 20000 & [2] \\
\hline LPMR & +120 & 14000 & [3] \\
\hline
\end{tabular}

Thicknesses are the maxima for each unit, in most cases they represent layer thicknesses. Notes:

[1] Thickness of the Cleveland Dyke means its width. The same value for $\Delta \rho$ is assumed for the Bolam Laccolith.

[2] Maximum thickness of the Weardale Granite, assumed to be of ellipsoidal shape, is for its vertical major axis.

[3] The LPMR layer is assumed to be underlain by crustal basement and mantle rocks with the same density as the reference Earth model.

Figure 14 illustrates a Noddy 'history', designed to capture the essential features of the geological structure of the study region. The associated 3-D structural model, for which Bouguer gravity anomalies $\Delta \mathrm{g}$ are calculated, is illustrated as a series of oblique views in Fig. 15. These views depict a model volume representing the map area in Fig. 13, for depths between O.D. and $10 \mathrm{~km}$. The various Noddy 'elements' are also defined, and their gravity effects calculated, for the surrounding volume, ensuring avoidance of numerical artefacts at the edges of the model region. Choices of values for $\Delta \rho$ and other parameters, such as thicknesses of model subdivisions, have been guided by the literature (e.g., [8,17]), as already noted. Over 1000 forward models have been run, to investigate effects of variations in parameter values and of introduction of additional Noddy elements into the solutions. The starting point for the 'history' in Fig. 14 is a Noddy 'strat' element representing the crustal basement and underlying mantle, for which $\Delta \mathrm{g}=0$, overlain by a $14 \mathrm{~km}$ thick layer with $\Delta \rho=+120 \mathrm{~kg} \mathrm{~m}^{-3}$, representing the LPMR, then a series of layers representing the lower part of the Carboniferous succession. Next is a 'plug' element, representing the Weardale Granite; this intrusion is assumed to have an ellipsoidal shape and to be characterised by $\Delta \rho=-50 \mathrm{~kg} \mathrm{~m}^{-3}$. In reality, of course, the Weardale Granite is older than any of the Carboniferous sediments, so an essential feature of any valid model is to ensure that its extent is confined to within the LPMR, as in Fig. 15.

The next sequence of model elements is intended to represent the main phase of slip on the Butterknowle Fault in the Early Carboniferous. The direct effect of the fault slip is represented by a Noddy 'fault' element. This model fault has initial dip $52^{\circ}$ and initial strike $070^{\circ}$, with $7500 \mathrm{~m}$ of slip (in a reference frame with the footwall fixed), with a planar surface passing through a point at $1200 \mathrm{~m}$ 


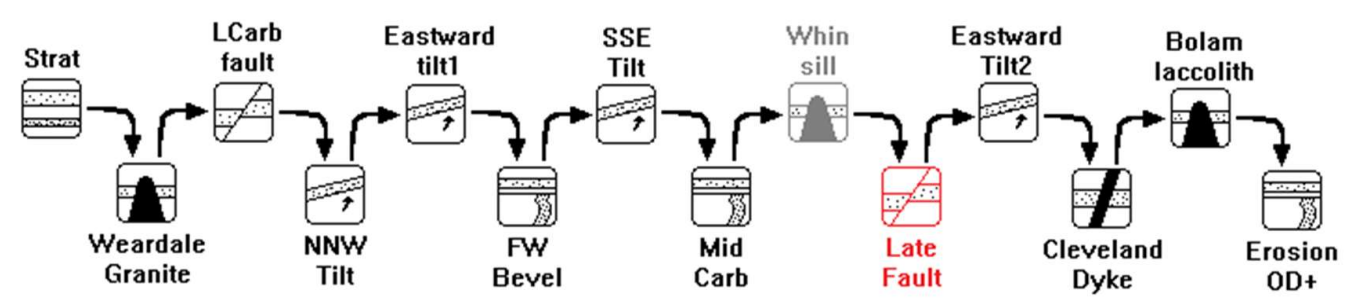

Figure 14. Representation of the 'history' of 'events' that combine to create the 3-D structural model (illustrated in Fig. 15), used for calculation of Bouguer anomalies in Noddy. The optional 'Late Fault' element is highlighted in red. The unused 'Whin sill element' is greyed out.

depth beneath NZ 2700030730 . The following elements are a 'tilt' by $16^{\circ}$ towards an azimuth of $345^{\circ}$, then an eastward tilt by $4^{\circ}$, then an 'unconformity' element in which all rock above a horizontal surface, positioned $900 \mathrm{~m}$ below O.D., is lost to erosion. Above this model unconformity, sediments are incorporated into the model to represent the middle part of the Carboniferous succession. Next, the succession is tilted by $10^{\circ}$ towards an azimuth of $154^{\circ}$. After this, another 'unconformity' element is used to remove any rock shallower than $900 \mathrm{~m}$ below O.D., and further sediment is added to represent the upper part of the Carboniferous succession. This sequence of elements is intended to represent the tilting of the hanging-wall of the Butterknowle Fault towards this fault and the associated tilting of the fault to a shallower dip during its main phase of slip, combined with erosional 'bevelling' of its footwall (which remained subaerial for much of the Early Carboniferous; Kimbell et al., 2010), combined with the evident eastward increase in the throw on the Butterknowle Fault and the eastward thickening of the Carboniferous sediments overlying its footwall (cf. Kimbell et al. [11]; Fig. 2). One could represent these aspects of structural development by a more complex model with successive increments of fault slip followed by incremental tilting and sedimentation, but the extra complexity thus introduced would add many model parameters whose values would need to be constrained; the present simplification captures the principal aspects.

The next element of the model is another 'plug' intended to provide the option of representing the intrusion of the Great Whin Sill, followed by another 'fault' element intended to represent the possibility that the 'Castle Fault' offsets the LPMR as depicted in Fig. 2. However, it was found that no choice of ellipsoidal 'plug', thin vertically and highly elongated horizontally, could achieve any systematic improvement in mismatch between observed and predicted Bouguer anomalies; consequently, in all solutions discussed the Great Whin Sill is not explicitly included. The model thus implicitly assumes that the Great Whin Sill maintains the same thickness at the same vertical position across the study region, departures from this assumption (caused by lateral variations in the thickness and/or depth of the sill) being a likely cause of mismatch between observed and predicted Bouguer anomalies. An additional complicating factor, also not considered in the present analysis, is any effect of contact metamorphism accompanying the intrusion of the Great Whin Sill on rock density. Devolatilization of coal and baking of coal and other sediments have been reported at distances of up to several hundred metres above and below the Great Whin Sill (e.g., [45]), and might cause sufficient increase in density to influence gravity measurements, given the accuracy tolerances of our study.

The remaining model elements represent the Palaeogene magmatism, involving extrusion of the Cleveland Dyke and intrusion of the associated Bolam Laccolith (Figs 3 and 4). The Bolam Laccolith is modelled as an ellipsoidal 'plug' with $\Delta \rho=+280 \mathrm{~kg} \mathrm{~m}^{-3}$, with a long axis of $1050 \mathrm{~m}$ at azimuth $110^{\circ}$ and a short axis of $340 \mathrm{~m}$ (consistent with [37]), centred $60 \mathrm{~m}$ below O.D. at NZ 19100 23200. The Cleveland Dyke is assumed to have the same density contrast, and to maintain a constant $50 \mathrm{~m}$ width through the study region, passing through NZ 1910023200 at an azimuth of $110^{\circ}$. Mills and Hull [37] reported its maximum thickness in the vicinity of the present study area as $\sim 27 \mathrm{~m}$ (near Fell Houses, NZ 1295 2489) but noted instances (e.g., near Buck Head, NZ 1439 2443) of this dyke widening downwards and other localities of outgrowths or 'apophyses' from this dyke, sometimes in the form of small sills. Sills (or 'sheets' of 'whinstone') and dykes, oriented subparallel or oblique to the main Cleveland Dyke, have indeed been reported over a substantial swath of territory (e.g., [37,114]; Fig. 
(a) Viewed from the northeast

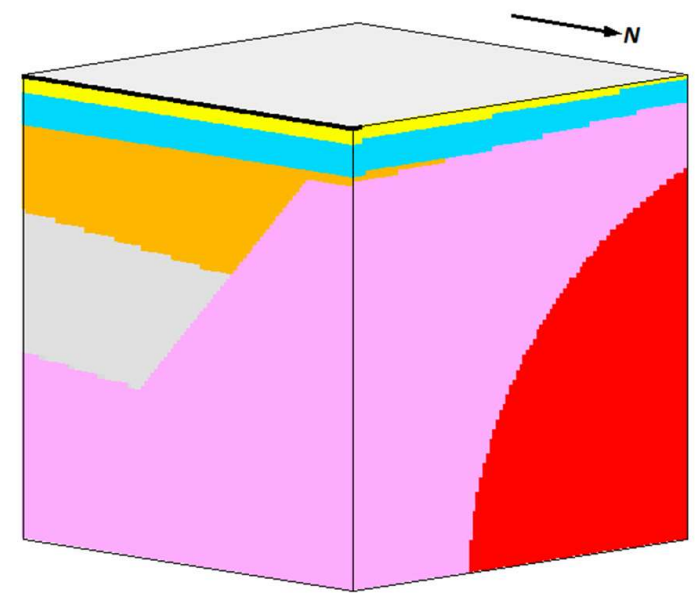

(c) Viewed from the southwest

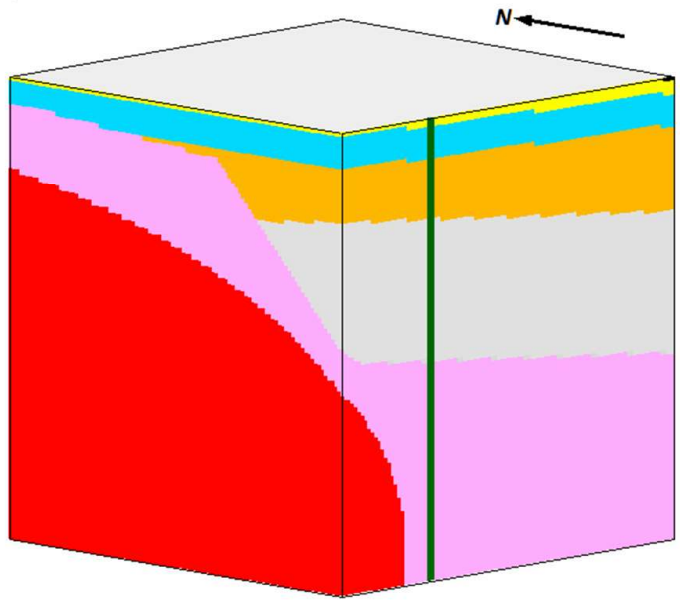

Key:

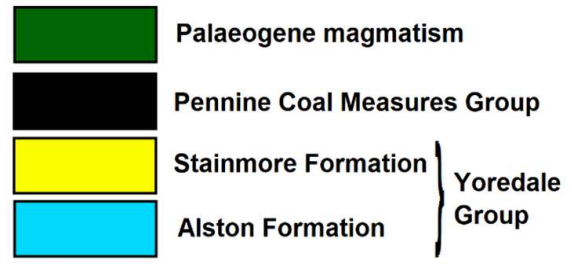

(b) Viewed from the southeast

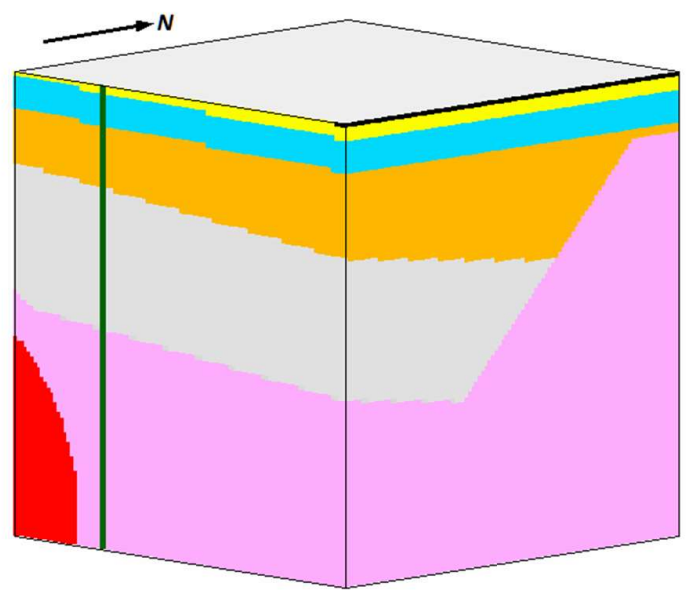

(d) Viewed from the northwest
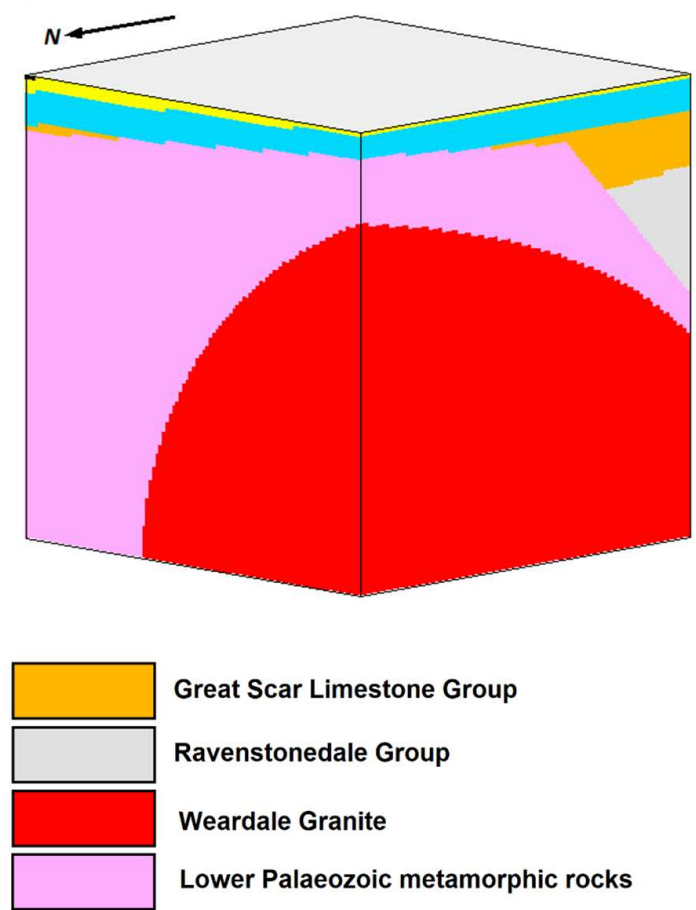

Great Scar Limestone Group

Ravenstonedale Group

Weardale Granite

Lower Palaeozoic metamorphic rocks

Figure 15. Oblique views of the 3-D structural model created by the sequence of 'events' in Fig. 14.

Fig. 4). For example, the Hilton no. 53 borehole (BGS reference NZ12SE30, at NZ 17473 23832) revealed $\sim 3 \mathrm{~m}$ of 'whinstone', tentatively attributed to the Palaeogene magmatism [37], at $\sim 24-27 \mathrm{~m}$ depth. The next model element is an eastward tilt by $1.5^{\circ}$, to represent the observed eastward tilting of the regional landscape, as a result of lateral variations in Cenozoic uplift (e.g., [35,115]). The final element is another unconformity to remove all rock above O.D., given that the intention of the data reduction procedure to generate the observed Bouguer anomalies (Fig. 13) has been to eliminate the gravitational effect of rock above this level. The width of the Cleveland Dyke in the model is chosen in part to reflect the observed downward widening and in part to emphasize the effect of this dyke in the modelling. Although the regional tilting (which is mostly Late Cenozoic; [35]) occurred after the Palaeogene magmatism, it has been deliberately placed earlier in the history (Fig. 14) to avoid any effect of the later tilting displacing the Bolam laccolith away from shallow depths where its presence may contribute to the observed Bouguer anomaly. 


\subsection{Results}

Figure 16 illustrates the variation in Bouguer anomaly for the structural model in Fig. 15, with the preferred set of densities for model components as in Table 3. Overall, the model mimics the observed Bouguer anomaly in Fig. 13, the mismatch being illustrated in Fig. 17. Typically, across the model area, the magnitude of this mismatch is $<<1 \mathrm{mgal}$, indicating a far better fit between data and model than for the previous modelling $[8,11,17]$. The largest-magnitude negative mismatch of -1.5 mgal is in the SW corner of the model (at NZ 17000 23000), decreasing northeastward to circa -0.4 mgal roughly halfway between West Auckland and Bildershaw (circa NZ 190 250). This area with negative mismatch gives way eastward into a zone of positive mismatch of $>1.0 \mathrm{mgal}$, to be discussed below. The depth (up to $\sim 5 \mathrm{~km}$ below O.D.) of the top LPMR and the position of the footwall escarpment of the Butterknowle Fault at depth in the West Auckland - Bildershaw area are constrained by the seismic section in Fig. 9. The mismatch in this area therefore cannot be eliminated by making the top LPMR significantly shallower beneath the hanging-wall or making the dip of the fault significantly gentler, which would have the effect of placing the top LPMR at a significantly shallower depth beneath this area in the footwall. Clearly, this mismatch might in principle be eliminated by increasing the density of either the LPMR or the sedimentary fill. However, the former adjustment would impair the match in many footwall localities, whereas the latter adjustment would worsen the mismatch in the more easterly part of the hanging-wall. As already noted, we suggest instead that the mismatch in this area may be caused by the unmodelled presence of the high-density Great Whin Sill with particularly high thickness. We tentatively suggest that the strong reflectors visible in the part of Fig. 9 in this area in the deeper part of the Stainmore Group may indicate the Great Whin Sill, mafic sills being well known to form strong seismic reflectors (e.g., [116]).
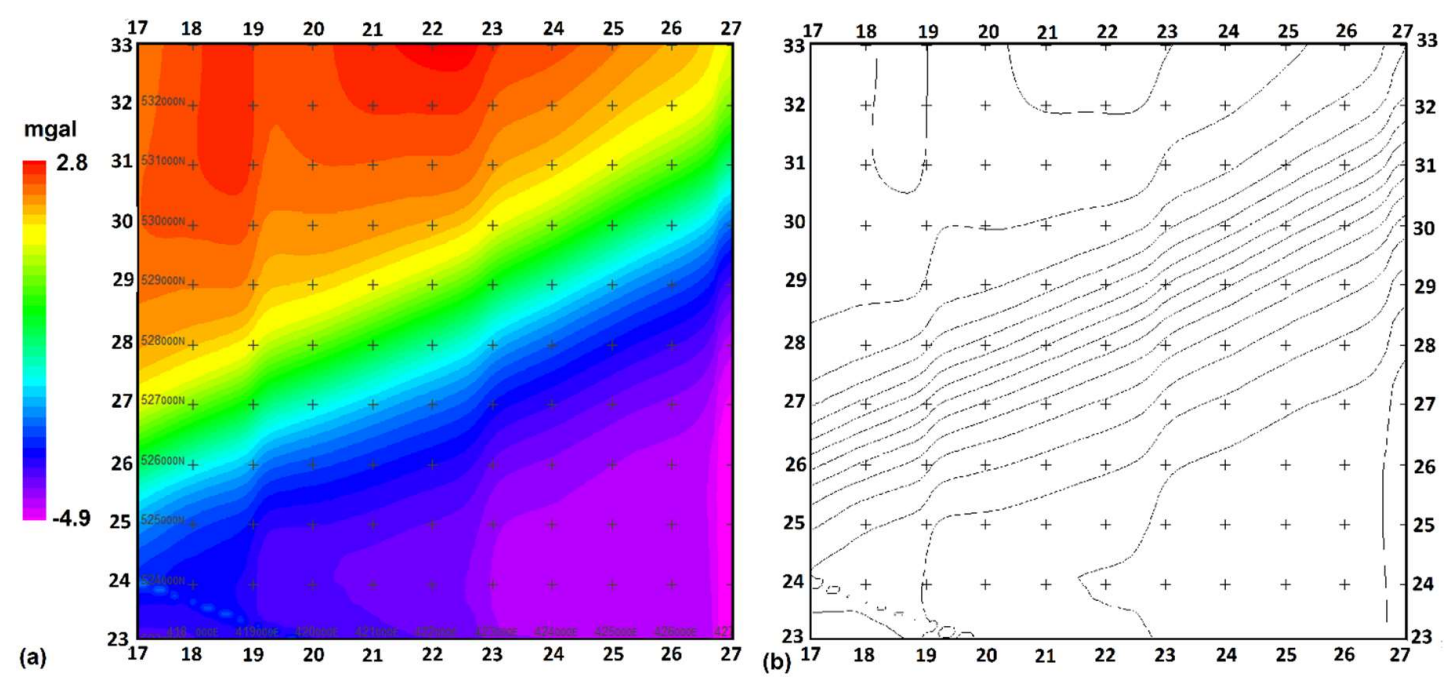

Figure 16. Bouguer anomaly predicted for the model in Fig. 15, using the display format of Fig. 13.

The model footwall cut-off of the Butterknowle Fault transects the study area from WSW to ENE (Fig. 13), passing $\sim 1.5 \mathrm{~km}$ south of Bishop Auckland town centre (circa NZ 210 287). There is a zone of typical width $\sim 2 \mathrm{~km}$, adjoining this footwall cutoff, with mismatch in the range $\sim 1-2$ mgal, peaking circa +2.4 mgal (circa NZ 205 292, 1 km SW of the town centre), dying out towards the NNW. We interpret this feature as a probable consequence of greater loss of mass of the LPMR from this footwall while it was subaerial during the Dinantian than we have allowed for in our modelling. However, we could find no geometrical shape within the options specified by Noddy that could improve the overall match. An alternative potential explanation is that the Weardale Granite (of lower density than the LPMR) is more extensive in the west-central part of our model area than we have allowed for. Nonetheless, the Weardale Granite is already rather more extensive in our model than it has previously been believed to be [17]. As already noted, Kimbell et al. [17] envisaged the SSE margin of this granite as an irregular boundary extending generally ENE-WSW from the NW outskirts of 
Durham, through Willington, to the vicinity of Eggleston, continuing westward subparallel to the Lunedale and Closehouse Faults (Fig. 3). With a boundary in this position, the Weardale Granite does not impinge into our model area. On the contrary, the margin of this granite in our model passes SSW between circa NZ 235330 and NZ 188 230, some $10 \mathrm{~km}$ farther SSE than the position previously advocated [17]. Kimbell et al. [17] incorporated arbitrary shapes for the top and sides of the pluton but constrained its base to be flat at a depth of $9 \mathrm{~km}$, whereas our modelling has been limited by the range of geometrical shapes available in Noddy, the pluton being modelled as an ellipsoid, albeit with no specific constraint on its base. Kimbell et al. [17] took the $9 \mathrm{~km}$ base of the pluton from Bott [111], although his analysis stated margins of uncertainty rather than providing an exact value. If, in reality, the top of the granite is flatter than we have inferred in the vicinity of its SSE margin, then the addition to the model of extra rock of relatively low density might eliminate the positive mismatch evident in the present solution (Fig. 16). Nonetheless, our inference that the Weardale Granite is more extensive than previously thought has significant implications for the regional geothermics, given that this granite is highly radiothermal and is under consideration as a source of geothermal heat (e.g., $[20,117,118])$. Other evidence that the Weardale Granite might be more extensive than previously thought is provided by the extent of metalliferous mineralization, which persists beyond the SSE margin of the granite as determined by Kimbell et al. [17] (see their Fig. 5). Since the granite is regarded as the cause of this mineralization (e.g., $[115,119]$ ), a greater extent of it makes the extent of the mineralization more readily explicable. On a related theme, a more southerly southern boundary of the Weardale Granite, adjoining the Butterknowle Fault, might account for the high heat flow in the Woodland Borehole, rather than the currently preferred explanation as a consequence of hydrothermal circulation [16]. One might indeed speculate that the difference in buoyancy between the low-density Weardale Granite and the higher-density LPMR might have determined the position of the Butterknowle Fault during the Dinantian, as the principal normal fault in the region, just as the Pennine Fault and Stublick Fault, which form the western and northern margins of the Alston Block (Fig. 2), also delineate the western and northern margins of the granite [17].
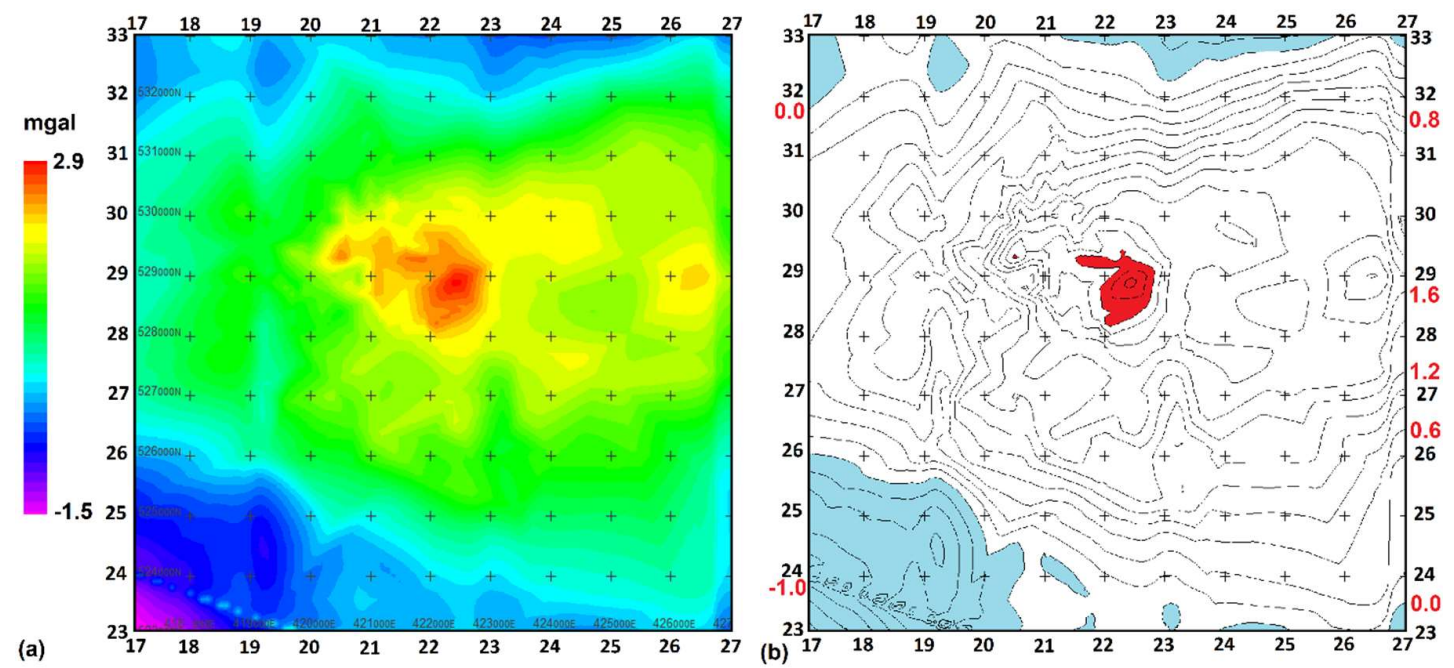

Figure 17. Mismatch between the predicted Bouguer anomaly in Fig. 16 and the observed Bouguer anomaly in Fig. 13, using the same display format as for Fig. 13 except the contour interval is $0.2 \mathrm{mgal}$ and shading has been used to identify values $<0$ and $>2.4$ mgal. Positive values denote localities where the predictions exceed the observations, indicating that the density of some part of the model beneath these localities is too high.

The largest positive mismatch between observed and modelled Bouguer gravity anomalies, $\sim+2.9$ mgal, is located circa NZ 225 289, in the hanging-wall of the Butterknowle Fault, $\sim 2 \mathrm{~km} \mathrm{SE}$ of Bishop Auckland town centre. It forms part of a roughly semi-circular zone of positive mismatches that can be traced across much of the hanging-wall, with a diameter of $\sim 5-6 \mathrm{~km}$, the magnitude of the 
mismatch generally tapering southwards, and eastwards away from the point of maximum mismatch, which adjoins the maximum mismatch in the footwall. To anticipate later discussion, we suggest that these features indicate a palaeo-valley, incised into the footwall escarpment, and the associated alluvial fan in the hanging-wall.

As a final point relating to the modelling results in Figs 16 and 17, we revisit the question of whether there is any possibility that the extant interpretation, with the 'Castle Fault' en echelon to the main Butterknowle Fault ([11,17]; Fig. 2), is correct. As already discussed, with this geometry, the $\sim 250 \mathrm{~m}$ throw on the Castle Fault, if offsetting the LPMR, would create an abrupt $\sim 2$ mgal variation in the Bouguer anomaly across the line of this fault (Fig. 11). There is no feature in the data (Fig. 13), or in the existing mismatch between observed and predicted Bouguer anomalies in Figs 16 and 17, to provide any basis for any such interpretation. Many models have been run with such a feature included but none provides any fit to data that would justify its inclusion; in the interests of brevity, no solution of this type is illustrated. As a check of our preferred 3-D solution, we re-ran the structural modelling for it, creating the results in Fig. 10(c). The succession of tilt 'events' incorporated into the structural model reduces the dip of the Butterknowle Fault from its initial $52^{\circ}$ to $49^{\circ}$ (Fig. 15). The geometry of the fault, thus predicted, would require an erosional 'bevel' of the footwall by up to $\sim 400$ $\mathrm{m}$ across a width of $\sim 1.5 \mathrm{~km}$, as illustrated in Fig. 10(c). The resulting loss of mass of the higherdensity LPMR might eliminate the over-prediction of Bouguer gravity, evident in Fig. 17, in this part of the model area (using equation (7), a typical thickness of $200 \mathrm{~m}$ and a density contract of $-300 \mathrm{~kg}$ $\mathrm{m}^{-3}$ would reduce the gravity anomaly by $\sim 2.5 \mathrm{mgal}$ ).

\section{Discussion}

We now discuss several issues that have emerged from our analysis. These include the geological interpretation of the mismatches in our gravity modelling (cf. Fig. 17), the implications of our results for geothermics, and the wider issues raised.

\subsection{Geological interpretation of gravity model}

As noted above, the principal mismatch features arising from our gravity modelling, both locally exceeding +2 mgal, occupy a narrow zone just inside the footwall cutoff and a semi-circular area with $\sim 6 \mathrm{~km}$ diameter in the hanging-wall. These has been tentatively interpreted as a palaeo-valley incised into the erosionally bevelled footwall and an associated alluvial fan in the hanging-wall.

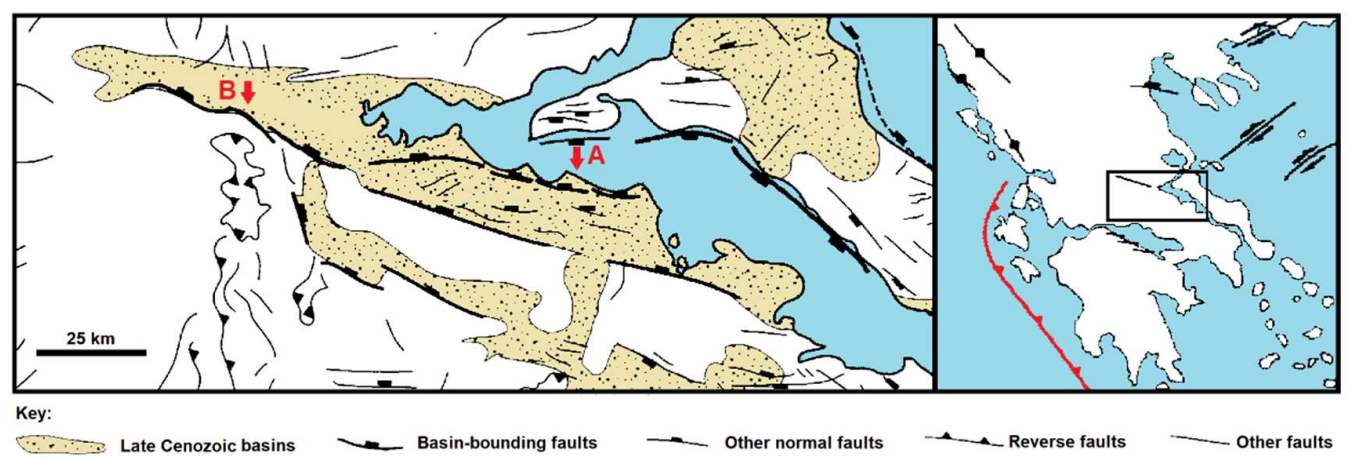

Figure 18. Structural map of central Greece, modified from Fig. 1 of Eliet and Gawthorpe [120], showing normal faults and Late Cenozoic extensional sedimentary basins. Inset shows location overlying the northward-subducting oceanic lithosphere of the African Plate. Locations and view directions of Fig. 19(a) and (b) are also shown. 


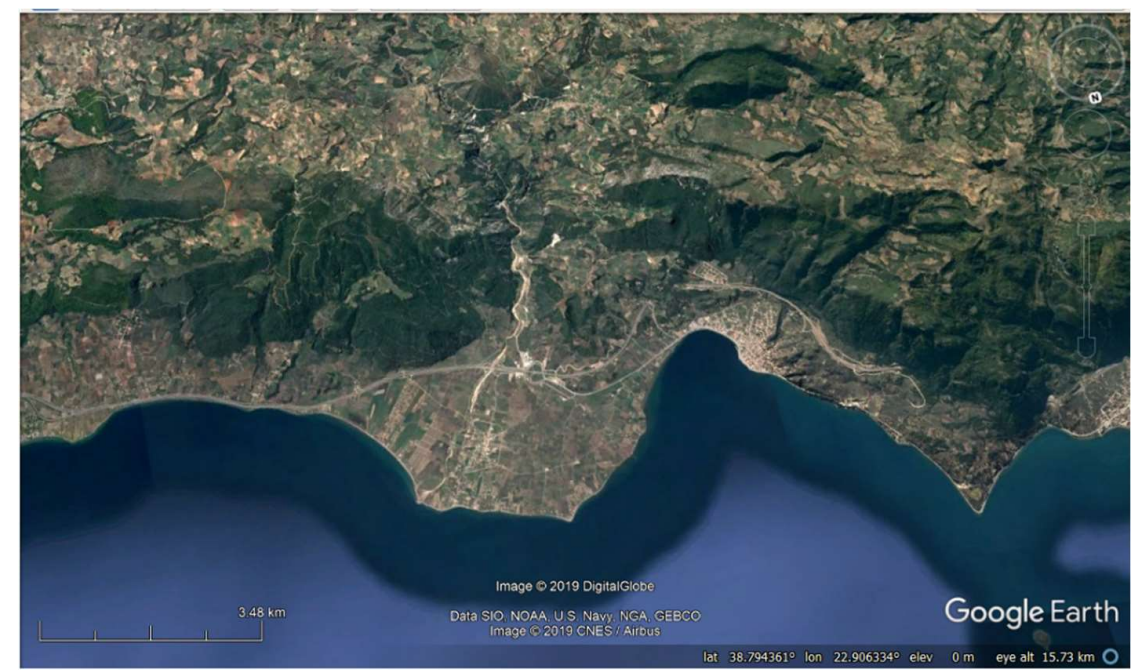

(a)

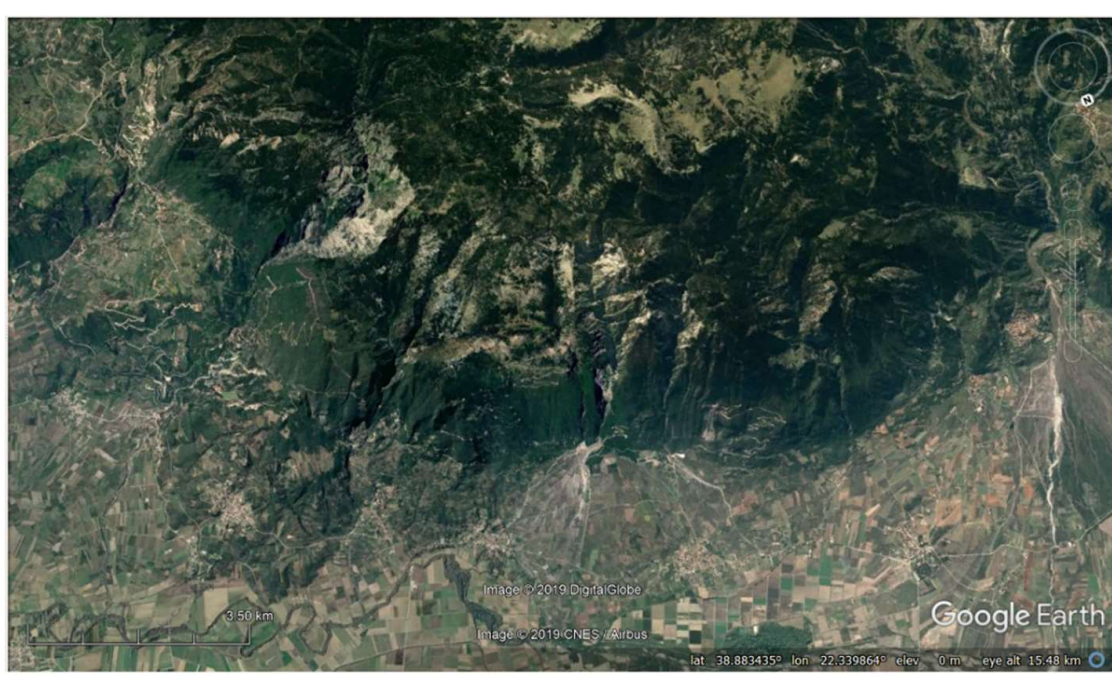

(b)

Figure 19. Google Earth images of active normal faults in central Greece, potential analogues for the Butterknowle Fault during the Early Carboniferous. (a) View SSW towards the coastline of the Gulf of Evvia east of Agios Konstantinos. A river (with $\sim 50 \mathrm{~km}^{2}$ catchment) has incised a gorge, up to $300 \mathrm{~m}$ deep and almost $1 \mathrm{~km}$ wide, through the Knimis uplands. These uplands form the footwall of the Arkitsa Fault (left) and Kamena Vourla Fault (right), the river exiting the footwall between these fault segments (as is typical for relatively large rivers in this region; e.g., [120]), where the faulting steps leftward by $\sim 1 \mathrm{~km}$. A $\sim 6 \mathrm{~km}{ }^{2}$ alluvial fan-delta has developed in the hanging-wall, where the coastline has prograded away from the normal fault escarpment. (b) View SSW towards the footwall escarpment of the Kompotades normal fault, bounding the southern margin of the Sperchios valley in its hanging-wall and the Oiti uplands ( $\sim 2000 \mathrm{~m}$ a.s.l.) in its footwall. Several streams are visible, which flow across the footwall for up to $\sim 8 \mathrm{~km}$, initially at the level of the surrounding bedrock, their lower reaches becoming increasingly entrenched (by up to $\sim 500 \mathrm{~m}$, forming 'wineglass canyons' up to $\sim 2 \mathrm{~km}$ wide) before they emerge through the footwall escarpment. This footwall rises from $\sim 100 \mathrm{~m}$ a.s.l., giving way above $\sim 800-1400 \mathrm{~m}$ a.s.l. to an erosional 'bevel' of the bedrock, which rises more gently southward to the summit area of the uplands.

To investigate this aspect further, we recall that the Dinantian extension of northern England involved backarc extension overlying northward subduction. Although plate tectonic reconstructions for this era differ between authors (e.g., [31,121,122,123]), they incorporate the required geometry of subduction. Comparison is therefore warranted with the modern Aegean region, where backarc extension is occurring above the northward-subducting African plate (Fig. 18(a)). We thus look to this latter region, and in particular to the well-documented array of active normal faults in central Greece, for candidates features to aid interpretation of the Butterknowle Fault dataset. Many workers have investigated the active faulting in central Greece: studies include investigations of the isostatic balance during extension (e.g., [124,125]), descriptive studies of fault exposures (e.g., [126]), integration of seismic, geodetic and structural datasets (e.g., [127,128]), tectonic syntheses (e.g., [129]), investigations of hanging-wall sedimentary processes (e.g., [130,131]), and investigations of the geometry and routing of drainage 
and sediment transport from subaerial footwall sources to hanging-wall depocentres (e.g., $[120,132,133])$. Informed by these works, and by the geometry of the Butterknowle Fault with a subaerial footwall during much of the extension and a marine hanging-wall depocentre (e.g., [11]), we focus on one particular analogue structure, the Sperchios-Arkitsa fault zone (Fig. 18). This structure is segmented; in the east, where the depocentre is marine, sediment supply (mostly from uplifted Late Cenozoic depocentres, which are now eroding) is mainly routed through transfer zones between adjacent normal fault segments (Fig. 19(a)); conversely, in the west, where the hanging-wall is fluvial, much of the drainage - in bedrock - is via small streams that have cut short, deeplyentrenched, valleys through the footwall escarpment. In both localities, much of the sediment reaches the hanging-wall in alluvial fans, with typical dimensions of several kilometres; although some sediment is reworked by marine or fluvial processes, much of it remains in the alluvial fans, emplaced against the uplifting footwall escarpment, which interfinger with the main bodies of hanging-wall sediment and become progressively buried by the hanging-wall subsidence.

Figure 19(b) illustrates the footwall escarpment of the Kompotades segment of the SperchiosArkitsa fault zone, a locality discussed at length by Eliet and Gawthorpe [120] and Whittaker and Walker [133]. Several streams are visible; they flow across the footwall for up to $\sim 8 \mathrm{~km}$, initially at the level of the surrounding bedrock, their lower reaches becoming increasingly entrenched (by depths of up to $\sim 500 \mathrm{~m}$ ) before they emerge through the footwall escarpment. The widths of these 'wineglass canyons' are up to $\sim 2 \mathrm{~km}$, comparable to the extent of the Bouguer anomaly mismatch in the Butterknowle Fault footwall (Fig. 17). Such comparison led us to attribute this mismatch to a fluvial gorge network, cut into this footwall during the Dinantian slip on the Butterknowle Fault.

As Fig. 15 shows, the gravity modelling indicates that the footwall cutoff of the Butterknowle Fault adjoins rocks of the Great Scar Limestone Group, for which a density contrast of $300 \mathrm{~kg} \mathrm{~m}^{-3}$ relative to the LPMR has been adopted (Table 3). As noted above, the $\sim-2$ mgal typical gravity mismatch along this footwall cutoff (Fig. 17) can be readily explained by an erosional footwall 'bevel', similar to that along the Kompotades Fault (Fig. 19(b)). The development of $\sim 4 \mathrm{~km}$ of heave on the Butterknowle Fault in the Bishop Auckland area (Fig. 15) during extension lasting 20 million years (see above) implies a rather low time-averaged extension rate of $\sim 0.2 \mathrm{~mm} \mathrm{a}^{-1}$, in contrast with the extension rates on major fault systems in central Greece that reach several millimetres per year (e.g., [128]). The climate of Britain during the Dinantian is thought, from evidence indicators such as palaeosols and seasonal growth rings of vegetation (e.g., [134,135,136,137]), to have been strongly seasonal, with alternating seasonal aridity and monsoonal rainfall. The combination of low slip rate and the anticipated potential erosional effects of this climate regime mean that significant erosion of any subaerial footwall escarpment can be expected. This regime gave way to a near continuous moist tropical climate during the Namurian and Westphalian (e.g., [31]).

As regards the feature that has been tentatively interpreted as a palaeovalley incised into the footwall, the observed Bouguer anomaly mismatch (Fig. 17) relative to the surrounding 'bevelled' footwall is a maximum of $\sim 0.8 \mathrm{mgal}$ (the difference between $\sim 2.4$ mgal over the palaeovalley feature and $\sim 1.6 \mathrm{mgal}$ over its surroundings). Taking the density contrast as $-300 \mathrm{~kg} \mathrm{~m}^{-3}$, once again, a Bouguer anomaly $25 \%$ of that calculated from equation (7) would indicate a palaeovalley depth of $\sim 250 \mathrm{~m}$. The resulting incised relief was evidently rather subdued in form compared with the Kompotades examples. Extending the analogy, we interpret the corresponding hanging-wall Bouguer anomaly mismatch as a consequence of the density contrast between the alluvial fan, created by the sediments that were emplaced via the footwall palaeovalley, and the surrounding - denser sediments (cf. Fig. 7). Westaway and Younger [19] identified a $\sim 50 \mathrm{~kg} \mathrm{~m}^{-3}$ density contrast between sandstone, a likely constituent (along with gravel and cobbles) of the alluvial fan rocks, and mudstone, a likely composition of the surrounding rocks. The data presented by Waltham ([138], p. 52) indicate a density contrast closer to $\sim 40 \mathrm{~kg} \mathrm{~m}^{-3}$. The laboratory measurements from Kimbell et al. [8] indicate greater contrasts in mean density, $120 \mathrm{~kg} \mathrm{~m}^{-3}$, these low densities evidently arising as a result of pore space between clasts, making the rock relatively porous. Applying the slab formula using the latter value, the $\sim 2.9$ mgal maximum Bouguer anomaly indicates a maximum thickness of $\sim 600 \mathrm{~m}$ of the alluvial fan deposits. These deposits thus represent only a small proportion of the 
thickness of the sedimentary fill in the Stainmore Basin, consistent with the nearby seismic profile (Fig. 7), and as expected (cf. [120]) for the relatively small drainage catchments that might be anticipated in the footwall escarpment of a major normal fault.

\subsection{Implications for geothermics}

As originally conceived in 2013-2014, the Bishop Auckland geothermal project would have involved drilling a well doublet from a pad near Auckland Castle (circa NZ 214 302). An initial vertical well would have been designed to intersect the downward planar continuation of the 'Castle Fault' that was presumed to exist within the LPMR. The temperature at $1 \mathrm{~km}$ depth had been estimated as $\sim 54{ }^{\circ} \mathrm{C}$ [3]. Taking the surface temperature as $9{ }^{\circ} \mathrm{C}$, the geothermal gradient in the sedimentary section down to $1 \mathrm{~km}$ depth is $45^{\circ} \mathrm{C} \mathrm{km}^{-1}$; extrapolation at the same gradient would predict a temperature of $\sim 80^{\circ} \mathrm{C}$ at the intended depth of the fault intersection, at $\sim 1.6 \mathrm{~km}$ depth. A more detailed calculation, incorporating the difference in thermal conductivity $\mathrm{k}$ between the LPMR and the overlying sediments, is also possible. Bott et al. [16] reported as a best estimate the sedimentary column sampled by the Woodland borehole has $\mathrm{k} \sim 1.4 \mathrm{~W} \mathrm{~m}^{-1}{ }^{\circ} \mathrm{C}^{-1}$; the above-mentioned geothermal gradient thus implies a heat flow of $\sim 63 \mathrm{~mW} \mathrm{~m}^{-2}$. Measurements of the properties of the LPMR in this area are unavailable; however, slate is widely cited as having $\mathrm{k} \sim 2 \mathrm{~W} \mathrm{~m}^{-1}{ }^{\circ} \mathrm{C}^{-1}$. Placing the boundary between the sediments and LPMR at $1.2 \mathrm{~km}$ below O.D. (as in Fig. 2) or $\sim 1.3 \mathrm{~km}$ below the land surface in this area, the temperature at this depth would be $\sim 68^{\circ} \mathrm{C}$ and that at $1.6 \mathrm{~km}$ depth, extrapolated at a geothermal gradient of $\sim 1.4 / 2 \times 45=\sim 32{ }^{\circ} \mathrm{C} \mathrm{km}^{-1}$, would be $\sim 77^{\circ} \mathrm{C}$. It was hoped that this fault would prove permeable; once this was established by testing the first well, a second well would be drilled, deviated either ENE or WSW, to intersect the 'Castle Fault' at the same depth, with a separation from the first well of maybe $\sim 1 \mathrm{~km}$. The resulting well doublet would have been used to provide hot water at $\sim 80^{\circ} \mathrm{C}$ or thereabouts for a heating network for the castle and adjacent buildings. Given what is now known, had the drilling proceeded as originally designed, it would not have encountered a fault at the intended position; the project would have failed.

Given the evident need for knowledge of the geometry of faulting beneath the site, to de-risk this project, the developer (Hotspur Geothermal Ltd.) commissioned several investigations. MVE (2014) reported on the fault geometry, as modelled using their MoVE software subject to different assumptions, proposing that the 'Castle Fault' might 'detach' at a depth as shallow as $650 \mathrm{~m}$ under the assumption of constant slip, or as deep as $\sim 3000 \mathrm{~m}$ under the assumption of constant heave. The present set of estimates in Fig. 10 supersede these results, subject to the assumption of constant heave but with distributed simple shear inclined at an acute angle to the vertical, indicating detachment at a depth of $\sim 1100 \mathrm{~m}$. Hotspur also commissioned reprocessing of seismic line 86-458 and reinterpretation of the results [139]. This $4450 \mathrm{~m}$ long seismic line runs generally WNW-ESE, through Bishop Auckland town centre (see https://ukogl.org.uk/ukogl-interactive-map/). Beginning circa NZ 200306 in Toronto, it proceeds ESE along Jubilee Street, crossing the River Wear at Newton Cap Bridge, at NZ 205 303, then through the town centre via Newton Cap Bank to NZ 207 300, then via High Bondgate and the Market Place to NZ 212 302, before leaving Bishop Auckland along Durham Road as far as NZ 225 295, continuing via lanes and minor roads to NZ 241 288, near Howlish. This seismic line therefore passes within a few hundred metres of the proposed drilling site, but to avoid damage to urban infrastructure the vibroseis sources were operated at reduced power, limiting signal quality, shot points in sensitive locations (on bridges and near historic buildings, including Auckland Castle) were omitted, and the various abrupt changes of direction at road junctions hampered the stacking of records. A succession of strong reflectors was recognized [139] at 0.4-0.52 s two way time at the WNW end of the profile and at 0.55-0.8 s two way time at its ESE end, which were interpreted as 'Dinantian carbonates'. The top of these reflectors was interpreted [139] as offset between 0.37 and 0.43 s two way time circa NZ 213 301, the Butterknowle Fault being regarded as 'detaching' in mudstone for a distance of $\sim 500 \mathrm{~m}$ at $\sim 430 \mathrm{~m}$ depth, before resuming a steep dip as the top of the carbonate succession is downthrown by $\sim 70 \mathrm{~m}$. However, this is the part of the seismic section where the signal quality is lowest, due to missed shot points and turns at road junctions. Furthermore, this $70 \mathrm{~m}$ offset is inconsistent with the $\sim 250 \mathrm{~m}$ throw of the 'Castle Fault' in this locality. In addition, this 
locality is only $300 \mathrm{~m}$ from the surface trace of the 'Castle Fault', so the fault geometry deduced [139] is implausible.

Our gravity survey was commissioned in the light of this report, to settle the question of the fault geometry. In summary, our gravity modelling indicates (Fig. 10(c)) that the buried footwall escarpment of the main Butterknowle Fault had been positioned correctly by previous BGS studies (e.g., [11]). However, our dense network of gravity measurements close to the point where a planar extrapolation of the 'Castle Fault' would cut the top of the LPMR (Fig. 12) makes clear that this fault does not do this; our structural modelling suggests that this fault 'detaches' near the base of the sedimentary column before linking to the main Butterknowle Fault (Fig. 10(c)), thus accommodating the final $\sim 250 \mathrm{~m}$ of slip on the latter structure. Compared with the other commissioned works (discussed above) our analysis was highly cost-effective for the geothermal developer; the imminent availability for field use of micro-electro-mechanical system gravimeters, which offer many advantages over conventional gravimeters (e.g., [140,141]), might therefore benefit future projects of this type. Such investigations might consistently enable structural interpretations essential for geothermal development to be validated or refuted at low cost; the lower value of heat compared with hydrocarbons necessitates a different approach to exploration.

Our results mean that the original drilling concept at the Auckland Castle site was superseded. An initial suggestion, assuming the same drilling pad location would be used, was to drill vertically initially, then once in the LPMR to deviate the wells to the SSE to intersect the Butterknowle Fault from its footwall. As Fig. 10(c) indicates, the horizontal leg of such a well design would be $\sim 1.5 \mathrm{~km}$ long, roughly doubling the length of drilling, the additional distance being in the LPMR that is impermeable and would be relatively difficult to drill due to its consolidated nature. Arguably a better concept would be to avoid the LPMR completely, by drilling diagonally down alongside the buried fault escarpment, just inside its hanging-wall. Such a design would be expected to pass through fractured rocks and our analysis also implies that significant matrix permeability would be encountered in the relatively coarse lithologies expected in this location. An optimum configuration, from the point of view of resource utilization, would be to drill in this manner (or drill vertically, from a pad nearer the hanging-wall cutoff) to near the base of the sedimentary succession, at a depth of $\sim 6 \mathrm{~km}$ (Figs. 10(c), 15). At a representative location (NZ 230 250), Busby and Terrington [12] estimated the temperature as $\sim 185^{\circ} \mathrm{C}$ at $5 \mathrm{~km}$ depth and $\sim 235^{\circ} \mathrm{C}$ at $7 \mathrm{~km}$ depth, implying $\sim 210{ }^{\circ} \mathrm{C}$ at $6 \mathrm{~km}$ depth. These estimates assume that the Carboniferous sediments have $\mathrm{k}=2.68 \mathrm{~W} \mathrm{~m}^{-1}{ }^{\circ} \mathrm{C}^{-1}$. Busby and Terrington [12] also estimated the surface heat flow in this vicinity as $\sim 85 \mathrm{~mW} \mathrm{~m}^{-2}$, comprising a raw measurement of $\sim 65 \mathrm{~mW} \mathrm{~m}^{-2}$ and a $\sim 20 \mathrm{~mW} \mathrm{~m}^{-2}$ correction for palaeoclimate. Westaway and Younger [19] showed via more detailed calculations that correction for palaeoclimate might increase the raw heat flow, measured at shallow depths, by $\sim 30 \%$, indicating that this estimate is reasonable for this particular locality. This relatively high value of $\mathrm{k}$ implies a sandstone-dominated lithology, although the significant radioactive heat production assumed in the sediments $\left(1.16 \mu \mathrm{W} \mathrm{m} \mathrm{m}^{-3}\right)$, which will cause a significant downward decrease in the geothermal gradient, is difficult to reconcile with non-radiogenic silica. For comparison, Westaway [142] estimated a temperature of $279{ }^{\circ} \mathrm{C}$ at $6 \mathrm{~km}$ depth by extrapolation of the geotherm in the Brafferton borehole, assuming the mudstone dominated lithology (and the associated $\mathrm{k} \sim 1.7 \mathrm{~W} \mathrm{~m}^{-1}{ }^{\circ} \mathrm{C}^{-1}$ ) at shallow depths persists throughout. The actual temperature at the $\sim 6 \mathrm{~km}$ deep base of the Stainmore Basin is probably between these limiting values. Temperatures as high as this can be readily used for electricity generation, the 'waste' heat from this activity being 'cascaded' for space heating or water heating or industrial process heat. Despite the evident high geothermal potential of the Bishop Auckland area, and the fact that the project had been significantly 'de-risked' through our efforts, an application for a contribution from public funds towards capital expenditure did not succeed. At present (July 2019), no plans exist for any deep geothermal development in the area.

\subsection{Wider implications}

The present study provides the first description of the research process necessary to validate a deep geothermal project in sedimentary rocks in Britain. This contrasts with the approach adopted 
for other recent projects in sedimentary rocks. The Science Central well (Fig. 3), drilled in 2011 to 1821 $\mathrm{m}$ (bottom hole temperature $73{ }^{\circ} \mathrm{C}$ ), was intended to exploit fracture permeability in the Dinantian Fell Sandstone Formation, in the vicinity of the Ninety Fathom Fault ([21]; Fig. 2). However, drilling took place in the footwall of this fault some $1.6 \mathrm{~km}$ from its footwall cutoff, being determined by the location of the Science Central redevelopment site in Newcastle upon Tyne city centre, placing the well bottom $\sim 3 \mathrm{~km}$ from this fault. At depth the Fell Sandstone proved to not be fractured; as already noted, its matrix also proved to be extremely tight, so this project ended up as a failure [118]. The drilling of this well was not preceded by any research process relating to the structural geology. Conversely, although it has developed as a shallow minewater geothermics project (e.g., [6]), it is well-known that the BGS-led UKGEOS Glasgow Geothermal Energy Research Field Site (GGERFS) was originally intended (when first proposed, in 2015-2016) as a validation of deep geothermal development in Carboniferous and Devonian sedimentary aquifers in central Scotland; hence, the site investigation report [5] covers deep geology. Although extremely thorough, this report [5] is essentially a literature review, supplemented by illustrations using seismic sections and views of subsurface three-dimensional geographical information systems (GIS) that are proprietary within BGS (see also below). It includes no component, analogous to the workflow in the present study, concerned with validation of any aspect of the structural geology that is critical to any proposal for geothermal development.

Currently, only one deep geothermal energy project is operational in Britain, at Southampton, where a well, dating from the early 1980s, reaches permeable Triassic sandstone at $76^{\circ} \mathrm{C}$, at $1827 \mathrm{~m}$ depth (e.g., [143]). This Southampton-1 well, originally intended as part of a doublet, was repurposed for heat production for a district heating scheme, with the used water discharged into the sea. Despite supplying since 1991 a thermal power of 2.2 MW (e.g., [143]), this project is unlikely to be repeated due to regulatory issues affecting discharge of waste water into the environment [142].

In terms of crustal properties, Britain is comparable to the Netherlands, where the typical geothermal gradient is $\sim 30^{\circ} \mathrm{C} \mathrm{km}^{-1}$ (e.g., [144]). However, unlike in Britain, where the production of deep geothermal heat has remained constant at $\sim 2 \mathrm{MW}$ from the single Southampton project, an extremely dynamic situation has developed. Deep geothermal heat production in the Netherlands grew from zero in 2006 to $221 \mathrm{MW}$ from 18 projects (averaging 12 MW per project) by the end of 2018 [145]. Schoopf [146] has summarized the reasons for this success story thus: the interest of and engagement with entrepreneurs in the horticulture sector, who wish to decarbonize the heating of greenhouses; the ready availability of sub-surface data, which is crucial for determining subsurface risk and thereby financing projects, a law dating from 1831 requiring all sub-surface data to be made public within five years of collection; and the role of the government, putting in place a risk-guarantee fund and a feed-in tariff for heat. In contrast, in the UK at present there is no government risk guarantee scheme for drilling costs and no clear plan to perpetuate the Renewable Heat Incentive subsidy for low-carbon heating projects. In the Netherlands, subsurface data is made available in the form of a three-dimensional (3-D) GIS, ThermoGIS (www.thermogis.nl), which is routinely updated and equipped with software tools (www.nlog.nl/en/tools) to facilitate preliminary site assessments (e.g., $[147,148])$. 3-D GIS technology, of which ThermoGIS is an example, is widely regarded as providing the future standard for documenting and archiving subsurface information (e.g., [149]), given its abilities to keep track of which data items are known and which are inferred, and to produce outputs (e.g., maps, cross-sections, and vertical logs) on demand.

In contrast, in the UK, BGS has a statutory role as a repository of subsurface data but with no remit to make such data publicly available. The furore that has developed in Britain about 'fracking' for shale gas, as a result of the microseismicity at the Preese Hall site in 2011, has focused attention on the quality of subsurface data in the UK. The uneven quality of geological mapping, including some quadrangles that have not been updated for decades and the general lack of differentiation between observations and deductions on the basis of structural interpretation, for example inferring faults to solve structural problems, has attracted widespread attention from environmental protesters, leading to severe criticism of projects (e.g., [151]). As a result, BGS public outputs now 

Your use of information and materials provided by the British Geological Survey (BGS) is at your own
risk. Please read any warnings given about the various limitations of what is provided.

BGS gives no warranty as to the quality or accuracy of the information or its suitability for any use. All implied conditions relating to the quality or suitability of the information, and all liabilities arising from the supply of the information (including any liability arising in negligence) are excluded to the fullest extent permitted by law.

BGS gives no warranty as to the accuracy or completeness of data or images in the form in which they are cached or downloaded to your computer, as they may be affected by on-line conditions over which BGS has no control.

Geological observations are made according to the prevailing understanding of the subject at the time. The quality of such observations may be affected by subsequent advances in knowledge, improved methods of interpretation, and better access to sampling locations.

Raw data may have been transcribed from analogue to digital format, or may have been acquired by means of automated measuring techniques. Although such processes are subjected to quality control to ensure reliability where possible, some raw data may have been processed without human intervention and may in consequence contain undetected errors.

Detail clearly defined and accurately depicted on large-scale maps may be lost when small-scale maps are derived from them.
Although samples and records are maintained with all reasonable care, there may be some deterioration in the long term.

The most appropriate techniques for copying original records are used, but there may be some loss of detail and dimensional distortion when such records are copied.

Data may be compiled from the disparate sources of information at BGS's disposal, including material donated to BGS by third parties, and may not have been subject to any verification or other quality control process.

Data, information and related records which have been donated to BGS have been produced for a specific purpose, and that may affect the type and completeness of the data recorded and any interpretation. The nature and purpose of data collection, and the age of the resultant material may your intended usage.

The data, information and related records supplied by BGS should not be taken as a substitute for specialist interpretations, professional advice and/or detailed site investigations. You must seek professional advice before making technical interpretations on the basis of the materials provided.

If a report or other output is produced for you on the basis of data you have provided to BGS, or your own data input into a BGS system, please do not rely on it as a source of information about other areas or geological features, as the report may omit important details.

Figure 20. Example disclaimer that any user of BGS electronic data is required to accept before download. This example accompanied a download [150] in July 2019.

include extensive disclaimers regarding accuracy (Fig. 20). On the same timescale, BGS has pioneered the development of GSI3D, one of the leading 3-D GIS software systems (e.g., [152]). BGS has also pioneered techniques for assessing and representing uncertainty within such systems, an essential element enabling their effective

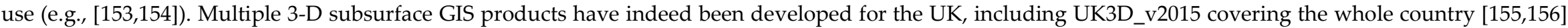
and detailed products for individual projects.

Unfortunately for the wider academic community, these subsurface GIS products are for internal use within BGS only; the rest of the community is only able to access static images exported from them or encrypted versions that can only be used within a proprietary viewer. The process of 'bastardizing' one 3-D GIS to

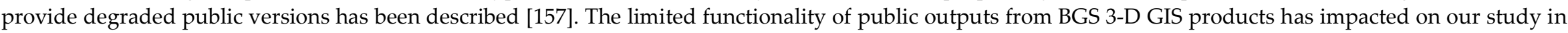
several ways. First, the analysis of the regional geothermics [12], which we have used to estimate the geothermal potential at Bishop Auckland, was based on a

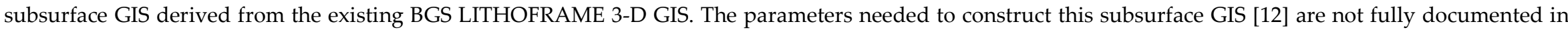

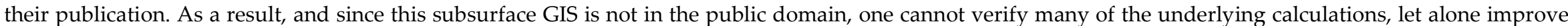

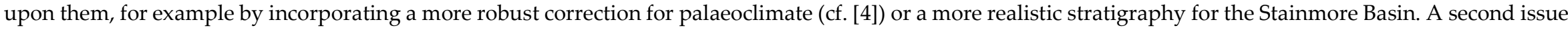




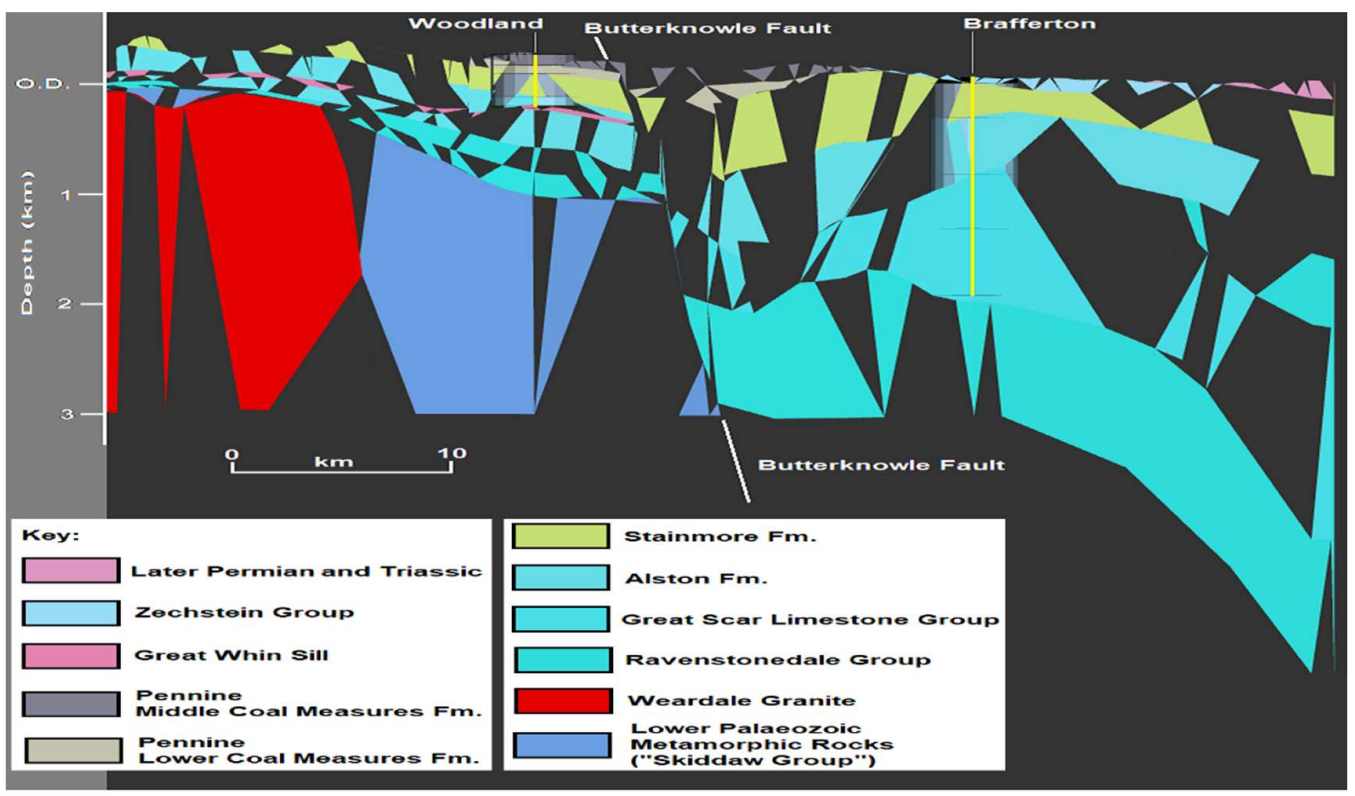

Figure 21. Cross-section at 5:1 vertical exaggeration, oriented $\mathrm{N} 72^{\circ} \mathrm{W}-\mathrm{S} 72^{\circ} \mathrm{E}$ between the Woodland and Brafferton boreholes, captured from the public version of UK3D_v2015 as a screen shot from its proprietary viewer, with key, depth scale, and annotation to make boreholes and the Butterknowle Fault more prominent added by hand. Beyond Woodland the cross-section is depicted as continuing NW for $19 \mathrm{~m}$, almost to its next tie with the Rookhope borehole. Beyond Brafferton it continues SE for $16 \mathrm{~km}$ to a point $10 \mathrm{~km}$ ESE of Darlington, at a tie with another UK3D_v2015 cross-section.

is that although our study area is covered by the Northumberland and Solway Basin 3-D GIS [33], this data source is not in the public domain. This non-availability made our own efforts to - in effect - develop our own 3-D subsurface GIS (Fig. 15) much more time-consuming than they need have been. A third issue was the possibility of making use in our study of the UK-wide UK3D_v2015 subsurface GIS [156]. The actual subsurface GIS being unavailable to us, we downloaded the public version that is accessible through its own proprietary viewer [150]. This includes a set of ribbon diagrams with borehole ties, one of which links the Woodland and Brafferton boreholes. As this section traverses the SW part of our study area, which we have found difficult to model, we examined the information provided. The resulting cross-section (Fig. 21) is difficult to follow, due to the use of almost identical colours for different stratigraphic divisions and the indistinct ornament for boreholes and for the Butterknowle Fault. It also gives the impression that the base of the Stainmore Basin succession is only $3 \mathrm{~km}$ deep near the hanging-wall cutoff of this fault. In addition, there is no indication why this depiction differs so radically from others, such as Fig. 2, covering the same area, when the UK3D_v2015 subsurface GIS was based on older sets of results such as this. In this region, the UK3D_v2015 3-D GIS is based primarily on the Northumberland and Solway Basin 3-D GIS, which was developed by digitizing diagrams such as that in Fig. 2, from Chadwick et al. [11], according to its authors $[33,155,156]$. Despite not having access to any of the original GIS products, we have noted a number of places where they are not accurate. For example, the surface trace of the Butterknowle Fault is depicted in Fig. $21 \sim 3 \mathrm{~km}$ ESE of the Woodland borehole, when the correct location (from [50]) is $\sim 1 \mathrm{~km}$ farther ESE. We found this particular cross-section to be of no help for our analysis; hence our reliance on older sources of information. We also noted, from illustrations provided by Terrington and Thorpe [33], that the Northumberland and Solway Basin 3-D GIS omits the 'Castle Fault' and appears to project the main Butterknowle Fault escarpment to the Earth's surface with a planar geometry, thus depicting the surface trace of the Butterknowle Fault in the wrong place (it is too far south by $>1 \mathrm{~km}$ ). We are concerned by the above issues, which are likely to become ingrained in the future literature, also by the absence of any procedure for developments of knowledge, such as our revision to the geometry of the Butterknowle Fault (Fig. 10(c)), to be 
incorporated into future 3-D GIS products. As already noted, availability of an accurate, fully functional, subsurface 3-D GIS would have saved much of the time required for the present study; for example, structural elements might then have been extracted from the 3-D GIS and used to automatically generate components of Noddy 'histories', rather than having to work these out by hand, which often required time-consuming trigonometrical calculations. Like in the Netherlands, transparent availability of 3-D GIS products may well be essential for the detailed structural studies necessary for cost-effective future development of deep geothermal energy in the UK.

\section{Conclusions}

The Butterknowle Fault is a major normal fault of Dinantian age in northern England, bounding the Stainmore Basin in its hanging-wall to the south and the Alston Block in its footwall to the north. This fault zone has been proposed as a source of deep geothermal energy; to facilitate the design of a geothermal project, investigation of its geometry, via the present study, was necessary. We have shown using three-dimensional modelling of a dense local gravity survey, combined with structural inversion, that this fault has a ramp-flat-ramp geometry, $250 \mathrm{~m}$ of latest Carboniferous / Early Permian downthrow having occurred on a fault surface that is not a planar updip continuation of that which had accommodated the many kilometres of Dinantian extension. The gravity survey also reveals relatively low-density sediments in the hanging-wall of the Dinantian fault, interpreted as porous alluvial fan deposits, indicating that a favourable geothermal target indeed exists in the Bishop Auckland area. This study demonstrates the value of gravity data for elucidating geological structure, even in a region such as Britain with well-studied geology, and highlights the need to verify published structural interpretations as future deep geothermal projects are designed. Although this project was carried out using a conventional Lacoste-Romberg gravimeter, future work of this type might be undertaken more expeditiously using microelectromechanical gravimeters, providing a practical low-cost option for geothermal exploration.

Supplementary Materials: The following are available online: File S1, corrected BGS gravity data; File S2, May 2015 gravity data processing; File S3, October 2015 gravity data processing; File S4: list of points with Bouguer gravity anomalies; and File S5, gridded Bouguer anomalies.

Author Contributions: Fieldwork design, R.W.; fieldwork implementation, R.W., S.M.W., A.W., T.L.H.; structural inversion, R.W.; gravity data reduction, R.W., S.M.W., A.W., R.M.; drafting of diagrams, R.W., S.M.W; article text, R.W.

Acknowledgments: This work, inspired by Paul Younger, was funded by Hotspur Geothermal Ltd (formerly Cluff Geothermal Ltd) on behalf of Auckland Castle Trust, Bishop Auckland. We thank Michael Feliks for arranging this funding. We also thank Richard Hobbs of Durham University for the loan of a gravimeter, the Auckland Castle Trust for logistical support (with especial thanks to Simon Davis, Claire Hughes, and Jonathan Ruffer), and many property owners in the Bishop Auckland area for allowing access. Robert Cullen, Stephen Halley, Chinelo Otiji, and Matt Sharp participated in the fieldwork.

Conflicts of Interest: We declare that we have no conflict of interest.

\section{References}

1. Downing, R.A., Gray, D.A. (eds). Geothermal energy - the potential in the United Kingdom. HMSO, London, 1986.

2. Downing, R.A., Gray, D.A. Geothermal resources of the United Kingdom. J. Geol. Soc., London, 1986, 143, 499507.

3. Busby, J., Kingdon, A., Williams, J. The measured shallow temperature field in Britain. Q. J. Eng. Geol. Hydrogeol., 2011, 44, 373-387.

4. Westaway, R., Younger, P.L. Accounting for palaeoclimate and topography: a rigorous approach to correction of the British geothermal dataset. Geothermics, 2013, 48, 31-51.

5. Monaghan, A.A., Ó Dochartaigh, B., Fordyce, F., Loveless, S., Entwisle, D., Quinn, M., Smith, K., Ellen, R., Arkley, S., Kearsey, T., Campbell, S.D.G., Fellgett, M., Mosca, I. UKGEOS - Glasgow Geothermal Energy Research Field Site (GGERFS): Initial summary of the geological platform. British Geological Survey Open Report, OR/17/006, 2017, 205 pp. 
6. Monaghan, A.A., Starcher, V., Ó Dochartaigh, B., Shorter, K., Burkin, J. UK Geoenergy Observatories: Glasgow Geothermal Energy Research Field Site - science infrastructure. UKGEOS Report G0100, British Geological Survey Open Report OR/18/037, 2018, 46 pp.

7. BGS. Glasgow Geothermal Energy Research Field Site. British Geological Survey, Keyworth, 2019. Available online: https://www.bgs.ac.uk/research/energy/esios/glasgow/home.html (accessed 5 February 2019)

8. Kimbell, G.S., Carruthers, R.M., Walker, A.S.D., Williamson, J.P. Regional geophysics of southern Scotland and northern England. Version 1.0 on CD-ROM. British Geological Survey, Keyworth, 2006. Available from: https://shop.bgs.ac.uk/Bookshop/product.cfm?p_id=KRGSCD

9. Ordnance Survey. A guide to coordinate systems in Great Britain. Report D00659, Ordnance Survey, Southampton, 2015, 43 pp. Available online: https://www.bnhs.co.uk/focuson/grabagridref/html/OSGB.pdf (accessed 5 September 2019)

10. Kirby, G.A., Baily, H.E., Chadwick, R.A., Evans, D.J., Holliday, D.W., Holloway, S., Hulbert, A.G., Pharaoh, T.C., Smith, N.J.P., Aitkenhead, N., Birch, B. The structure and evolution of the Craven Basin and adjacent areas. British Geological Survey Subsurface Memoir. The Stationery Office, London, 2000, 130 pp.

11. Chadwick, R.A., Halliday, D.W., Holloway, S., Hulbert, A.G. The structure and evolution of the Northumberland-Solway Basin and adjacent areas. British Geological Survey Subsurface Memoir. HMSO, London, 1995, 90 pp.

12. Busby, J., Terrington, R. Assessment of the resource base for engineered geothermal systems in Great Britain. Geothermal Energy, 2017, 5 (7), 18 pp, doi: 10.1186/s40517-017-0066-Z

13. Bott, M.H.P., Masson-Smith, D. Gravity measurements over the northern Pennines. Geol. Mag., 1953, 90, 127130.

14. Bott, M.H.P., Masson-Smith, D. The geological interpretation of a gravity survey of the Alston Block and the Durham Coalfield. Q. J. Geol. Soc., London, 1957, 113, 93-118.

15. Dunham, K.C., Dunham, A.C., Hodge, B.L., Johnson, G.A.L. Granite beneath Viséan sediments with mineralization at Rookhope, northern Pennines. Q. J. Geol. Soc., London, 1965, 121, 383-417.

16. Bott, M.H.P., Johnson, G.A.L., Mansfield, J., Wheilden, J. Terrestrial heat flow in North-east England. Geophys. J. R. Astron. Soc., 1972, 21, 277-288.

17. Kimbell, G.S., Young, B., Millward, D., Crowley, Q.G. The North Pennine batholith (Weardale Granite) of northern England: new data on its age and form. Proc. Yorkshire Geol. Soc., 2010, 58, 107-128.

18. Whittaker, A. (ed.). Atlas of onshore sedimentary basins in England and Wales: post-Carboniferous tectonics and stratigraphy. Blackie, Glasgow, 1985.

19. Westaway, R., Younger, P.L. Unravelling the relative contributions of climate change and ground disturbance to subsurface temperature perturbations: case studies from Tyneside, UK. Geothermics, 2016, 64, 490-515.

20. Manning, D.A.C., Younger, P.L., Smith, F.W., Jones, J.M., Dufton, D.J., Diskin, S. A deep geothermal exploration well at Eastgate, Weardale, UK: a novel exploration concept for low-enthalpy resources. J. Geol. Soc., London, 2007, 164, 371-382.

21. Younger, P.L., Manning, D.A.C., Millward, D., Busby, J.P., Jones, C.R.C., Gluyas, J.G. Geothermal exploration in the Fell Sandstone Formation (Mississippian) beneath the city centre of Newcastle upon Tyne, UK: the Newcastle Science Central Deep Geothermal Borehole. Q. J. Eng. Geol. Hydrogeol., 2016, 49, 350-363.

22. Temple, D. The Collieries of County Durham. Trade Union Printing, Newcastle upon Tyne, 1994.

23. Jones, J.M., Magraw, D., O’Mara, P.T. Carboniferous Westphalian Coal Measures. In: Johnson, G.A.L. (ed.), Robson's Geology of North East England. Transactions of the Natural History Society of Northumbria, vol. 56, part 5. The Natural History Society of Northumbria, Newcastle upon Tyne, 1995, pp. 267-282.

24. Forster, W. A treatise on a section of the strata from Newcastle upon Tyne to the mountain of Cross Fell in Cumberland. Preston and Heaton, Newcastle upon Tyne, 1809, 156 pp.

25. Sopwith, T. An account of the mining districts of Alston Moor, Weardale and Teesdale in Cumberland and Durham. W. Davidson, Alnwick, 1833, 183 pp.

26. Burgess, I.C., Mitchell, M. Visean lower Yoredale limestones on the Alston and Askrigg Blocks, and the base of the D2 zone in northern England. Proc. Yorkshire Geol. Soc., 1976, 40, 613-630.

27. McKenzie, D.P. 1978. Some remarks on the development of sedimentary basins. Earth Planet. Sci. Lett., 40, 2532.

28. Bott, M.H.P., Swinburn, P.M., Long, R.E. Deep structure and origin of the Northumberland and Stainmore Troughs. Proc. Yorkshire Geol. Soc., 1984, 44, 479-495 
29. Fraser, A.J., Gawthorpe, R.L. Tectono-stratigraphic development and hydrocarbon habitat of the Carboniferous in northern England. In Tectonic Events Responsible for Britain's Oil and Gas Reserves, Hardman, R.F.P., Brooks, J., eds., Spec. Publ. Geol. Soc., London, 1990, 55, 49-86.

30. Collier, R.E.L. The Lower Carboniferous Stainmore Basin, N England: extensional basin tectonics and sedimentation. J. Geol. Soc., London, 1991, 148, 379-390.

31. Waters, C.N., Davies S.J. Carboniferous: extensional basins, advancing deltas and coal swamps. In Geological History of Britain and Ireland, Woodcock, N., Strachan. R., eds. Blackwell, Oxford, 2000, pp. 173-223.

32. Warr, L.N. The Variscan orogeny: the welding of Pangaea. In Geological History of Britain and Ireland, Woodcock, N., Strachan. R., eds. Blackwell, Oxford, 2000, pp. 271-294.

33. Terrington, R.L., Thorpe, S. Metadata report for the Northumberland and Solway Basin 1:250 000 geological model. British Geological Survey Open Report, OR/13/049, 2014, 20 pp.

34. Green, P.F., Westaway, R., Manning, D.A.C., Younger, P.L. Cenozoic cooling and denudation in the North Pennines (northern England, UK) constrained by apatite fission-track analysis of cuttings from the Eastgate Borehole. Proc. Geol. Assoc., 2012, 123, 450-463.

35. Westaway R. Isostatic compensation of Quaternary vertical crustal motions: coupling between uplift of Britain and subsidence beneath the North Sea. J. Quat. Sci., 2017a, 32, 169-182.

36. Westaway, R. How local crustal properties influence the amount of denudation derived from low temperature thermochronometry. Geology Forum Comment e438, 2018a; doi: 10.1130/G39982C.1

37. Mills, D.A.C., Hull, J.H. Geology of the country around Barnard Castle. Memoir for 1:63,360 scale geological map sheet 32 (England \& Wales). Her Majesty's Stationery Office, London, 1976, 385 pp.

38. Johnson, G.A.L. (Ed.). Robson's Geology of North East England. Transactions of the Natural History Society of Northumbria, vol. 56, part 5. The Natural History Society of Northumbria, Newcastle upon Tyne, 1995.

39. Mills, D.A.C., Holliday, D.W. Geology of the district around Newcastle upon Tyne, Gateshead and Consett: Memoir for 1:50 000 Scale Geological Map Sheet 20 (England and Wales). The Stationery Office, London, 1998, 148 pp.

40. Francis, E.H. Magma and sediment-I: Emplacement mechanism of Late Carboniferous tholeiite sills in northern Britain. J. Geol. Soc., London, 1982, 139, 1-20.

41. Goulty, N.R. Emplacement mechanism of the Great Whin and Midland Valley dolerite sills. J. Geol. Soc., London, 2005, 162, 1047-1056.

42. Hamilton, M.A., Pearson D. Precise U-Pb age for the Great Whin dolerite complex, N.E. England, and its significance. In Dyke Swarms: Keys for Geodynamic Interpretation, Srivastava, R.K., ed. Springer, Berlin, 2011, pp. 495-504.

43. Timmerman, M.J. Timing, geodynamic setting and character of Permo-Carboniferous magmatism in the foreland of the Variscan Orogen, NW Europe. In Permo-Carboniferous Magmatism and Rifting in Europe, Wilson, M., Neumann, E.-R., Da Vies, G.R., Timmerman, M.J., Heeremans, M., Larsen, B.T., eds. Geol. Soc., London, Spec. Publ., 2004, 223, 41-74.

44. Monaghan, A.A., Pringle, M.S. ${ }^{40} \mathrm{Ar} /{ }^{39} \mathrm{Ar}$ geochronology of Carboniferous-Permian volcanism in the Midland Valley, Scotland. In Permo-Carboniferous Magmatism and Rifting in Europe, Wilson, M., Neumann, E.-R., Da Vies, G.R., Timmerman, M.J., Heeremans, M., Larsen, B.T., eds. Geol. Soc., London, Spec. Publ., 2004, 223, 219-241.

45. Randall, B.A.O. The Great Whin Sill and its associated dyke suite. In Robson's Geology of North East England, Johnson, G.A.L., ed. Transactions of the Natural History Society of Northumbria, vol. 56, part 5, pp. 319 327. The Natural History Society of Northumbria, Newcastle upon Tyne, 1995.

46. Cornwell, J.D., Wadge, A.J. Geophysical investigations in the Closehouse-Lunedale area. Report WF/MR/80/031, Institute of Geological Sciences, London, 1980, $27 \mathrm{pp}$.

47. Waters, C.N., Dean, M.T., Jones, N.S., Somerville, I.D. Cumbria and the northern Pennines. In A Revised Correlation of Carboniferous Rocks in the British Isles, Waters, C.N., Somerville, I.D., Jones, N.S., Cleal, C.J., Collinson, J.D., Waters, R.A., Besly, B.M., Dean, M.T., Stephenson, M.H., Davies, J.R., Freshney, E.C., Jackson, D.I., Mitchell, W.I., Powell, J.H., Barclay, W.J., Browne, M.A.E., Leveridge, B.E., Long, S.L., McLean, D., eds. Geol. Soc., London, Spec. Rep. 26, 2011, pp. 82-88.

48. Liss, D., Owens, W.H., Hutton, D.H.W. New palaeomagnetic results from the Whin Sill complex: evidence for a multiple intrusion event and revised virtual geomagnetic poles for the late Carboniferous for the British Isles. J. Geol. Soc., London, 2004, 161, 927-938. 
49. Johnson, G.A.L., Somerville, I.D., Tucker, M.E., Cózar, P. Carboniferous stratigraphy and context of the Seal Sands No. 1 Borehole, Teesmouth, NE England: the deepest onshore borehole in Great Britain. Proc. Yorkshire Geol. Soc., 2011, 58, 173-196.

50. IGS. Barnard Castle (Sheet 32, England and Wales), solid edition, of 1:63,360 scale geological map. Ordnance Survey, Southampton, for Institute of Geological Sciences, London, 1969.

51. Mori, H., Mori, N., Wallis, S., Westaway, R., Annen, C. The importance of heating duration for Raman CM thermometry: evidence from contact metamorphism around the Great Whin Sill intrusion, U.K. J. Metamorphic Geol., 2017, 35, 165-180.

52. Cairney, T., Frost, R.C. A case study of mine water quality deterioration, Mainsforth Colliery, County Durham. J. Hydrol., 1975, 25, 275-293.

53. Stone, P., Millward, D., Young, B., Merritt, J.W., Clarke, S.M., McCormac, M., Lawrence, D.J.D. British Regional Geology: Northern England. Fifth edition. British Geological Survey, Keyworth, 2010.

54. Wanless, H.R., Shepard, F.P. Sea level and climatic changes related to Late Paleozoic cycles. Geol. Soc. Am. Bull., 1936, 47, 1177-1206.

55. Heckel, P.H. Sea-level curve for Pennsylvanian eustatic marine transgressive-regressive depositional cycles along midcontinent outcrop belt, North America. Geology, 1986, 14, 330-334.

56. Gibling, M.R., Bird, D.J. Late Carboniferous cyclothems and alluvial paleovalleys in the Sydney Basin, Nova Scotia. Geol. Soc. Am. Bull., 1994, 106, 105-117.

57. Waters, C.N., 2011. Definitions of chronostratigraphic subdivisions: geochronology and event stratigraphy. In A Revised Correlation of Carboniferous Rocks in the British Isles, Waters, C.N., Somerville, I.D., Jones, N.S., Cleal, C.J., Collinson, J.D., Waters, R.A., Besly, B.M., Dean, M.T., Stephenson, M.H., Davies, J.R., Freshney, E.C., Jackson, D.I., Mitchell, W.I., Powell, J.H., Barclay, W.J., Browne, M.A.E., Leveridge, B.E., Long, S.L., McLean, D., eds. Geol. Soc., London, Spec. Rep. 26, 2011, pp. 3-10.

58. International Commission on Stratigraphy. International Chronostratigraphic Chart, 2018.

59. Woolacott, D. On a boring at Roddymoor Colliery, near Crook, Co. Durham. Geol. Mag., 1923, 60, 50-62.

60. Younger, P.L. 1993. Possible environmental impact of the closure of two collieries in County Durham. J. Inst. Water Env. Management, 7, 521-531.

61. Waggonways. Waggonways in North East England, 2009. Available online: https://sites.google.com/site/waggonways/ (accessed 18 June 2019).

62. Bateson, L., Lawrence, D. Case study for the application of Terrafirma groundmotion services to areas of abandoned mining: Northumberland, UK. British Geological Survey Open Report OR/12/055, 2012, 8 pp.

63. Kennedy, J.R., Koth, K.R., Carruth, R.L. Surface and subsurface microgravity data in the vicinity of Sanford Underground Research Facility, Lead, South Dakota. U.S. Geological Survey Open-File Report 2015-1043, 2015, $32 \mathrm{pp}$.

64. Younger, P.L. Hydrogeochemistry of minewaters flowing from abandoned coal workings in County Durham. Q. J. Eng. Geol., 1995, 28, S101-S113.

65. Parkin, G., Adams, R. Using catchment models for groundwater problems: evaluating the impact of mine dewatering and groundwater abstraction. In Hydrology in a Changing Environment, Wheater, H., Kirby, C., eds. Wiley, Chichester, 1998, pp. 269-279.

66. Neymeyer, A., Williams, R.T., Younger, P.L. Migration of polluted mine water in a public supply aquifer. $Q$. J. Eng. Geol. Hydrogeol., 2007, 40, 75-84.

67. Bearcock, J., Smedley, P.L. Baseline groundwater chemistry: the Magnesian Limestone of County Durham and North Yorkshire. British Geological Survey Open Report, OR/09/030, 2009, 63 pp.

68. Harrison, R., Scott, W.B., Smith, T. A note on the distribution, levels and temperatures of minewaters in the Northumberland and Durham coalfield. Q. J. Eng. Geol., 1989, 22, 355-358.

69. Turner, B.R., Robson, D.A., Dearman, W.R., Jones, J.M., Magraw, D., Smith, F.W. Structure. In Robson's Geology of North East England, Johnson, G.A.L., ed. Transactions of the Natural History Society of Northumbria, vol. 56, part 5. The Natural History Society of Northumbria, Newcastle upon Tyne, 1995, pp. 331-343.

70. Magraw, D., Clarke, A.M., Smith, D.B. The stratigraphy and structure of part of the South-East Durham Coalfield. Proc. Yorkshire Geol. Soc., 1963, 34, 153-208.

71. Hickling, H.G.A. Prospects of undersea coalfield extension in the North-East. Trans. Inst. Mining Eng., 1950, 109, 659-671. 
72. Price, R.H. Comment on 'The geological interpretation of a gravity survey of the Alston Block and the Durham Coalfield' by Bott, M.H.P., Masson-Smith, D. Q. J. Geol. Soc., London, 1957, 113, 132-133.

73. Smith, D.B., Francis, E.A. Geology of the country Between Durham and West Hartlepool. Memoir for 1:63,360 scale geological map sheet 27 (England \& Wales). Her Majesty's Stationery Office, London, 1967.

74. Praeg, D. Diachronous Variscan late-orogenic collapse as a response to multiple detachments: a view from the internides in France to the foreland in the Irish Sea. In Permo-Carboniferous Magmatism and Rifting in Europe, Wilson, M., Neumann, E.-R., Davies, G.R., Timmerman, M.J., Heeremans, M., Larsen, B.T., eds. Geol. Soc., London, Spec. Publ., 2004, 223, 89-138.

75. Dunham, K.C. Geology of the Northern Pennine orefield. Volume 1. Tyne to Stainmore. British Geological Survey, London, 1990, 300 pp.

76. Collier, R.E.L. Tectonic evolution of the Northumberland Basin: the effects of renewed extension upon an inverted extensional basin. J. Geol. Soc., London, 1989, 146, 981-989.

77. Ziegler, P.A. Evolution of sedimentary basins in North-West Europe. In Petroleum geology of the continental shelf of North-West Europe, Illing, L.V., Hobson, G.D., eds. Heyden \& Son, London, 1981, pp. 3-39.

78. Glennie, K.W. Early Permian-Rotliegend. In Introduction to the Petroleum Geology of the North Sea, Glennie, K.W., ed. Blackwell, Oxford, 1984, pp. 41-60.

79. De Paola, N., Holdsworth, R.E., McCaffrey, K.J.W. The influence of lithology and pre-existing structures on reservoir-scale faulting patterns in transtensional rift zones. J. Geol. Soc., London, 2005, 162, 471-480.

80. White, N.J., Jackson, J.A., McKenzie, D.P. The relationship between the geometry of normal faults and that of the sedimentary layers in their hanging walls. J. Struct. Geol., 1986, 8, 897-909.

81. Fowler, A. Evidence for a new major fault in North-East England. Geol. Mag., 1945, 82, 245-250.

82. Færseth, R.B. Shale smear along large faults: continuity of smear and the fault seal capacity. J. Geol. Soc., London, 2006, 163, 741-751.

83. Ehrlich, R., Gabrielsen, R.H. The complexity of a ramp-flat-ramp fault and its effect on hanging-wall structuring: an example from the Njord oil field, offshore mid-Norway. Petroleum Geosci., 2004, 10, 305-317.

84. Ellis, P.G., McClay, K.R. Listric extensional fault systems: results of analogue model experiments. Basin Res., 1988, 1, 55-70.

85. Childs, C., Nicol, A., Walsh, J.J., Watterson, J. Growth of vertically segmented normal faults. J. Struct. Geol., 1996, 18, 1389-1397.

86. Nicol, A., Watterson, J., Walsh, J.J., Childs, C. The shapes, major axis orientations and displacement patterns of fault surfaces. J. Struct. Geol., 1996, 18, 235-248.

87. Wilkins, S.J., Gross, M.R. Normal fault growth in layered rocks at Spit Mountain, Utah: influence of mechanical stratigraphy on dip linkage, fault restriction and fault scaling. J. Struct. Geol., 2002, 24, 14131429.

88. Schöpfer, M.P.J., Childs, C., Walsh, J.J. Two-dimensional distinct element modeling of the structure and growth of normal faults in multilayer sequences: 1. Model calibration, boundary conditions, and selected results. J. Geophys. Res., 2007, 112, B10401, 15 pp., doi: 10.1029/2006]B004902.

89. Schöpfer, M.P.J., Childs, C., Walsh, J.J. Two-dimensional distinct element modeling of the structure and growth of normal faults in multilayer sequences: 2. Impact of confining pressure and strength contrast on fault zone geometry and growth. J. Geophys. Res., 2007, 112, B10404, 16 pp., doi: 10.1029/2006JB004903.

90. Schöpfer, M.P.J., Childs, C., Walsh, J.J., Manzocchi, T., Koyi, H.A. Geometrical analysis of the refraction and segmentation of normal faults in periodically layered sequences. J. Struct. Geol., 2007, 29, 318-335.

91. Vrolijk, P.J., Urai, J.L., Kettermann, M. Clay smear: Review of mechanisms and applications. J. Struct. Geol., 2016, 86, 95-152.

92. NEIMME. An Account of the strata of Northumberland \& Durham as proved by Borings \& Sinkings, Volume A-B. North of England Institute of Mining \& Mechanical Engineers, Newcastle upon Tyne, 1878.

93. NEIMME. An Account of the strata of Northumberland $\mathcal{E}$ Durham as proved by Borings $\mathcal{E}$ Sinkings, Volume L-R. North of England Institute of Mining \& Mechanical Engineers, Newcastle upon Tyne, 1887.

94. NEIMME. An Account of the strata of Northumberland \& Durham as proved by Borings \& Sinkings, Volume S-T. North of England Institute of Mining \& Mechanical Engineers, Newcastle upon Tyne, 1894.

95. NEIMME. An Account of the strata of Northumberland \& Durham as proved by Borings $\mathcal{E}$ Sinkings, Supplement. North of England Institute of Mining \& Mechanical Engineers, Newcastle upon Tyne, 1910.

96. Benedicto, A., Séguret, M., Labaume, P. Interaction between faulting, drainage and sedimentation in extensional hanging-wall syncline basins: Example of the Oligocene Matelles Basin (Gulf of Lion rifted 
margin, SE France). In The Mediterranean Basins: Tertiary Extension Within the Alpine Orogen, Durand, B., Jolivet, L., Horvath, F., Séranne, M., eds. Geol. Soc., London, Spec. Publ., 1999, 156, 81-108.

97. Long Wei, Li Zhongquan, Li Ying, Chen Junliang, Li Hongkui, Wan Shuangshuang. Control of fault plane geometry on the formation of a normal fault related anticline: an experimental approach. Nature Scientific Reports, 2017, 7, 153, 5 pp., doi: 10.1038/s41598-017-00249-x.

98. Westaway, R. Integrating induced seismicity with rock mechanics: a conceptual model for the 2011 Preese Hall fracture development and induced seismicity. In Geomechanical and Petrophysical Properties of Mudrocks, Rutter, E.H., Mecklenburgh, J., Taylor, K.G., eds. Geol. Soc., London, Spec. Publ., 2017, 454, 327-359.

99. Morley, C.K. The impact of multiple extension events, stress rotation and inherited fabrics on normal fault geometries and evolution in the Cenozoic rift basins of Thailand. In The Geometry and Growth of Normal Faults, Childs, C., Holdsworth, R.E., Jackson, C.A.-L., Manzocchi, T., Walsh, J.J., Yielding, G., eds. Geol. Soc., London, Spec. Publ., 2017, 439, 413-445.

100. Worthington, R.P., Walsh, J.J. Timing, growth and structure of a reactivated basin-bounding fault. In The Geometry and Growth of Normal Faults, Childs, C., Holdsworth, R.E., Jackson, C.A.-L., Manzocchi, T., Walsh, J.J., Yielding, G., eds. Geol. Soc., London, Spec. Publ., 2017, 439, 511-531.

101. Kearey, P., Brooks, M. Gravity Surveying. In An Introduction to Geophysical Exploration, 2nd Ed., Kearey, P., Brooks, M., eds. Blackwell Science, Cardiff, 1984, pp. 125-135.

102. Telford, W.M., Geldart, L.P., Sheriff, R.E. Applied Geophysics. Cambridge University Press, 1990, 770 pp.

103. Walsh, J.J., Watterson, J. Dips of normal faults in British Coal Measures and other sedimentary sequences. J. Geol. Soc., London, 1988, 145, 859-873.

104. Tully, M.C., Howell, P.M. Bouguer gravity anomaly map of the United Kingdom and continental shelf, 1:250 000 scale, sheet 54 N-06 W, Tyne-Tees. Institute of Geological Sciences, London, 1978.

105. Jackson, J.A., McKenzie, D.P. The geometrical evolution of normal fault systems. J. Struct. Geol., 1983, 5, 471482.

106. Westaway, R., Kusznir, N.J., 1993. Fault and bed 'rotation' during continental extension: block rotation or vertical shear? J. Struct. Geol, 15, 753-770 (with 1993 Correction: J. Struct. Geol., 15, 1391).

107. Hammer, S. Terrain corrections for gravimeter stations. Geophysics, 1939, 4, 184-194.

108. Van Camp, M., Vauterin, P. Tsoft: graphical and interactive software for the analysis of time series and Earth tides. Comp. Geosci., 2005, 31, 631-640.

109. Jones, H.K, Morris, B.L, Cheney, C.S, Brewerton, L.J, Merrin, P.D, Lewis, M.A, MacDonald, A.M, Coleby, L.M, Talbot, J.C, McKenzie, A.A, Bird, M.J, Cunningham, J, Robinson, V.K. The physical properties of minor aquifers in England and Wales. British Geological Survey Technical Report, WD/00/4, 2000, 234 pp.

110. Stobbs, A.W. Memories of the LNER - southwest Durham. Published by the author, Penrith, 1989, 80 pp.

111. Bott, M.H.P. Geophysical investigations of the northern Pennine basement rocks. Proc. Yorkshire Geol. Soc., 1967, 36, 139-168.

112. Johnson, G.A.L. Skiddaw Slates proved in the Teesdale Inlier. Nature, 1961, 190, 996-997.

113. Pavlis, N.K., Holmes, S.A., Kenyon, S.C., Factor, J.K.. The development and evaluation of the Earth Gravitational Model 2008 (EGM2008). J. Geophys. Res., 2012, 117, B04406, 38 pp., doi: 10.1029/2011JB008916

114. Randall, B.A.O. The Tertiary dykes. In Robson's Geology of North East England, Johnson, G.A.L., ed. Transactions of the Natural History Society of Northumbria, vol. 56, part 5, pp. 327-329. The Natural History Society of Northumbria, Newcastle upon Tyne, 1995.

115. Smith, F.W. The mineralization of the Alston Block. In Robson's Geology of North East England, Johnson, G.A.L., ed. Transactions of the Natural History Society of Northumbria, vol. 56, part 5, pp. 344-352. The Natural History Society of Northumbria, Newcastle upon Tyne, 1995.

116. Warner, M. Absolute reflection coefficients from deep seismic reflections. Tectonophysics, 1990, 173, 15-23.

117. Younger, P.L., Manning, D.A.C. Hyper-permeable granite: lessons from test-pumping in the Eastgate Geothermal Borehole, Weardale, UK. Q. J. Eng. Geol. Hydrogeol., 2010, 43, 5-10.

118. Gluyas, J.G., Adams, C.A., Busby, J.P., Craig, J., Hirst, C., Manning, D.A.C., McCay, A., Narayan, N.S., Robinson, H.L., Watson, S.M., Westaway, R., Younger, P.L. Keeping warm: a review of deep geothermal potential of the UK. Proc. Inst. Mech. Eng., Part A: J. Power and Energy, 2018, 232, 115-126.

119. Dunham, K.C. The genesis of the north Pennine ore deposits. Q. J. Geol. Soc., London, 1934, 90, 689-720.

120. Eliet, P., Gawthorpe, R. Drainage development and sediment supply within rifts, examples from the Sperchios Basin, central Greece. J. Geol. Soc., London, 1995, 152, 883-893. 
121. Woodcock, N.H., Soper, N.J., Strachan, R.A. A Rheic cause for the Acadian deformation in Europe. J. Geol. Soc., London, 2007, 164, 1023-1036.

122. Nance, R.D., Gutiérrez-Alonso, G., Keppie, J.D., Linnemann, U., Murphy, J.B., Quesada, C., Strachan, R.A., Woodcock, N.H. A brief history of the Rheic Ocean. Geosci. Frontiers, 2012, 3, 125-135.

123. Eckelmann, K., Nesbor, H.-D., Königshof, P., Linnemann, U., Hofmann, M., Lange, J.-M., Sagawe, A. Plate interactions of Laurussia and Gondwana during the formation of Pangaea - Constraints from U-Pb LASF-ICP-MS detrital zircon ages of Devonian and Early Carboniferous siliciclastics of the Rhenohercynian zone, Central European Variscides. Gondwana Res., 2014, 25, 1484-1500.

124. Westaway, R. The Quaternary evolution of the Gulf of Corinth, central Greece: coupling between surface processes and flow in the lower continental crust. Tectonophysics, 2002, 348, 269-318.

125. Westaway, R. Improved modelling of the Quaternary evolution of the Gulf of Corinth, incorporating erosion and sedimentation coupled by lower-crustal flow. Tectonophysics, 2007, 440, 67-84.

126. Jackson, J.A., McKenzie, D.P. A hectare of fresh striations on the Arkitsa Fault, central Greece. J. Struct. Geol., 1999, 21, 1-6.

127. Roberts, G.P., Ganas, A. Fault-slip directions in central and southern Greece measured from striated and corrugated fault planes: Comparison with focal mechanism and geodetic data. J. Geophys. Res., 2000, 105, 23,443-23,462.

128. England, P.C., Houseman, G.A., Nocquet, J.M. Constraints from GPS measurements on the dynamics of deformation in Anatolia and the Aegean. J. Geophys. Res., Solid Earth, 2016, 121, 8888-8916.

129. Goldsworthy, M., Jackson, J.A., Haines, J. The continuity of active fault systems in Greece. Geophys. J. Int., 2002, 148, 596-618.

130. Cundy, A.B., Gaki-Papanastassiou, K., Papanastassiou, D., Maroukian, H., Frogley, M.R., Cane, T. Geological and geomorphological evidence of recent coastal uplift along a major Hellenic normal fault system (the Kamena Vourla fault zone, NW Evoikos Gulf, Greece). Mar. Geol., 2010, 271, 156-164.

131. Pechlivanidou, S., Cowie, P.A., Hannisdal, B., Whittaker, A.C., Gawthorpe, R.L., Pennos, C., Riiser, O.S. Source-to-sink analysis in an active extensional setting: Holocene erosion and deposition in the Sperchios rift, central Greece. Basin Res., 2018, 30, 522-543.

132. Valkanou K., Karymbalis E., Papanastassiou D., Gaki-Papanastassiou K., Giles P. Analysis of relationships among coastal alluvial fans and their contributing catchments in North Evoikos Gulf (central Greece). Bull. Geol. Soc. Greece, 2013, 47, 344-355.

133. Whittaker, A.C., Walker, A.S. Geomorphic constraints on fault throw rates and linkage times: Examples from the Northern Gulf of Evia, Greece. J. Geophys. Res., Earth Surf., 2015, 120, 137-158.

134. Wright, V.P. Equatorial aridity and climatic oscillations during the Early Carboniferous, southern Britain. J. Geol. Soc., London, 1990, 147, 359-363.

135. Vanstone, S.D. Early Carboniferous (Mississippian) paleosols from southwest Britain; influence of climatic change on soil development. J. Sed. Res., 1991, 61, 445-457.

136. Falcon-Lang, H.J. The Early Carboniferous (Asbian-Brigantian) seasonal tropical climate of Northern Britain. Palaios, 1999, 14, 116-126.

137. Falcon-Lang, H.J. The Early Carboniferous (Courceyan-Arundian) monsoonal climate of the British Isles: evidence from growth rings in fossil woods. Geol. Mag., 1999, 136, 177-187.

138. Waltham, T. Foundations of Engineering Geology, 3rd ed. Spon, London, 2009, 97 pp.

139. Hornet. Interpretation of the Butterknowle Fault on Seismic Line UK86-458. Report for Cluff Geothermal Limited, April 2015. Hornet Geoconsulting Ltd, Kings Lynn, 2015, 25 pp.

140. Middlemiss, R.P., Samarelli, A., Paul, D.J., Hough, J., Rowan, S., Hammond, G.D. Measurement of the Earth tides with a MEMS gravimeter. Nature, 2016, 531, 614-617.

141. Middlemiss, R.P., Bramsiepe, S.G., Douglas, R., Hough, J., Paul, D.J., Rowan, S., Hammond, G.D. Field tests of a portable MEMS gravimeter. Sensors, 2017, 17 (11), 2571, doi: 10.3390/s17112571.

142. Westaway, R. Deep Geothermal Single Well heat production: critical appraisal under UK conditions. Q. J. Eng. Geol. Hydrogeol., 2018, 51, 424-449.

143. Barker, J.A., Downing, R.A., Gray, D.A., Findlay, J., Kellaway, G.A., Parker, R.H., Rollin, K.E. Hydrogeothermal studies in the United Kingdom. Q. J. Eng. Geol. Hydrogeol., 2000, 33, 41-58.

144. Bonté, D., van Wees, J.-D. Verweij, J.M. Subsurface temperature of the onshore Netherlands: new temperature dataset and modelling. Netherlands J. Geosci., 2012, 91, 491-515. 
145. Provoost, M., Albeda, L., Godschalk, B., van der Werff, B., Schoof, F. Geothermal energy use, country update for The Netherlands. European Geothermal Congress 2019, The Hague, The Netherlands, 11-14 June 2019, paper CUR-19, 2019, 8 pp.

146. Schoopf, F. The success story of geothermal development in The Netherlands. European Geothermal Energy Council, 2019. Available online: https://www.egec.org/the-success-story-of-geothermal-development-inthe-netherlands/ (accessed 2 July 2019)

147. Van Wees, J.D, Kronimus, A., Van Putten, M., Pluymaekers, M., Mijnlieff, H., Van Hoof, P., Obdam, A., Kramers, L. Geothermal aquifer performance assessment for direct heat production - Methodology and application to Rotliegend aquifers. Netherlands J. Geosci., 2012, 91, 651-665.

148. Vrijlandt, M.A.W., Struijk, E.L.M., Brunner, L.G., Veldkamp, J.G., Witmans, N., Maljers, D., van Wees, J.D. ThermoGIS update: a renewed view on geothermal potential in the Netherlands. European Geothermal Congress 2019, The Hague, The Netherlands, 11-14 June 2019, paper 226, 2019, 10 pp.

149. Pavlis, T.L., Mason, K.A. The new world of 3D geologic mapping. GSA Today, 2017, 27, 4-10.

150. BGS. Regional subdivision of the National Bedrock Fence Diagram of the United Kingdom, UK3D v2015: England North 3D pdf. British Geological Survey, 2015b. Available online: https://www.bgs.ac.uk/downloads/start.cfm?id=3079 (accessed 3 July 2019)

151. Smythe, D.K. Planning application no. WSCC/083/13/KD by Celtique Energie to drill at Boxal Bridge, Wisborough Green, West Sussex: Critique of environmental statement in the context of relevant geology and hydrogeology, $2014 . \quad$ Available online: https://www.davidsmythe.org/fracking/Smythe\%20Celtique\%20planning\%20application\%20Wisborough \%20Green\%20June2014\%20v1.3.pdf (accessed 12 September 2019)

152. Price, S.J., Burke, H.F., Terrington, R.L., Reeves, H., Boon, D., Scheib, A. The 3D characterisation of the zone of human interaction and the sustainable use of underground space in urban and peri-urban environments: case studies from the UK. Z. Deutsch. Gesellschaft für Geowissenschaften, 2010, 161, 219-235.

153. Clarke, S. Confidence in geological interpretation: A methodology for evaluating uncertainty in common two and three-dimensional representations of subsurface geology. British Geological Survey Internal Report IR/04/164, 2004, 33 pp.

154. Lark, R.M., Mathers, S.J., Thorpe, S., Arkley, S.L.B., Morgan, D.J., Lawrence, D.J.D. A statistical assessment of the uncertainty in a 3-D geological framework model. Proc. Geol. Assoc., 2013, 124, 946-958.

155. Mathers, S.J., Terrington, R.L., Waters, C.N., Leslie, A.G. GB3D - a framework for the bedrock geology of Great Britain. Geosci. Data J., 2014, 1, 30-42, doi: 10.1002/gdj3.9.

156. Waters, C.N., Terrington, R.L., Cooper, M.R., Raine, R.B., Thorpe, S. The construction of a bedrock geology model for the UK: UK3D_v2015. British Geological Survey Report, OR/15/069, 2015, 22 pp.

157. Monaghan, A.A., Arkley, S.L.B., Whitbread, K., McCormac, M. Clyde superficial deposits and bedrock models released to the ASK Network 2014: a guide for users. Version 3. British Geological Survey Open Report OR/14/013, 2014, 35 pp. 